\title{
The Cognitive-Emotional Design and Study of Architectural Space: A Scoping Review of Neuroarchitecture and Its Precursor Approaches
}

\author{
Juan Luis Higuera-Trujillo ${ }^{1,2, *(\mathbb{D}}$, Carmen Llinares ${ }^{1}$ and Eduardo Macagno ${ }^{3} \mathbb{C}$ \\ 1 Institute for Research and Innovation in Bioengineering (i3B), Universitat Politècnica de València, \\ 46022 Valencia, Spain; cllinare@omp.upv.es \\ 2 Escuela de Arquitectura, Arte y Diseño (EAAD), Tecnologico de Monterrey, Monterrey 72453, Mexico \\ 3 Division of Biological Sciences, University of California San Diego, La Jolla, CA 92093-0116, USA; \\ emacagno@ucsd.edu \\ * Correspondence: jlhiguera@i3b.upv.es or jlhiguera@tec.mx; Tel.: +34-963-877-518
}

Citation: Higuera-Trujillo, J.L.; Llinares, C.; Macagno, E. The Cognitive-Emotional Design and Study of Architectural Space:

A Scoping Review of

Neuroarchitecture and Its Precursor Approaches. Sensors 2021, 21, 2193. https://doi.org/10.3390/s21062193

Academic Editor: Nicola Lopomo

Received: 22 December 2020

Accepted: 17 March 2021

Published: 21 March 2021

Publisher's Note: MDPI stays neutral with regard to jurisdictional claims in published maps and institutional affiliations.

Copyright: () 2021 by the authors. Licensee MDPI, Basel, Switzerland. This article is an open access article distributed under the terms and conditions of the Creative Commons Attribution (CC BY) license (https:// creativecommons.org/licenses/by/ $4.0 /)$.

\begin{abstract}
Humans respond cognitively and emotionally to the built environment. The modern possibility of recording the neural activity of subjects during exposure to environmental situations, using neuroscientific techniques and virtual reality, provides a promising framework for future design and studies of the built environment. The discipline derived is termed "neuroarchitecture". Given neuroarchitecture's transdisciplinary nature, it progresses needs to be reviewed in a contextualised way, together with its precursor approaches. The present article presents a scoping review, which maps out the broad areas on which the new discipline is based. The limitations, controversies, benefits, impact on the professional sectors involved, and potential of neuroarchitecture and its precursors' approaches are critically addressed.
\end{abstract}

Keywords: neuroarchitecture; emotional design; neuroscience; architecture; built environment; review

\section{Introduction}

Architecture has various effects on people. Studies have been undertaken into architectural aspects most open to objectification such as those related to structure, construction, and installations of buildings. There exists a broad background with standards and norms, that supports these aspects [1]. However, these are not the only factors involved. The environment also has effects on humans at the cognitive level (understood as the processing and appraisal of perceived information) and the emotional level (understood as the adaptive reactions to the perceived information), which both operate through closely interrelated systems [2]. For example, it has been found that noise and a lack of vegetation can generate stress [3,4], and stress associated with the built environment can even negatively affect life expectancy [5]. Studies on specific spaces have shown a variety of cognitive-emotional impacts, such as poorer patient recoveries in hospital rooms that lack relaxing external views of greenery [6]. Thus, the architecture has cognitive-emotional repercussions.

"Designerly ways of knowing" (distinct from the best-known scientific forms of knowledge [7]) has been, traditionally, the main way to address the cognitive-emotional dimension of architecture [8]. Through this way, which offers a great economy of means, architects have explored and exploited some of the perceptual foundations of the experience of space. However, it is particularly linked to subjective issues in decision-making [9], whose use may result in biases [10]. This can lead to inadequate results in responding to the users' cognitive-emotional needs. Although many approaches have addressed this dimension of architecture, they have not overcome some of these intrinsic limitations and, in part, because of this, have not been adopted as practical design tools. 
Neuroscience studies the nervous system from different areas, some of which are promising in this respect [11,12]. At a general level, the application of neuroscience to architecture is often termed "neuroarchitecture" [13]. Although bidirectional human-space influence, and its impact on neural activity [14], is not new, the modern recording of experimental subjects' neural activity during exposure to physical and simulated environmental situations provides a framework for future design and studies. For example, neuroarchitecture has allowed researchers to study some design variables in-depth, which reduce the stress, previously mentioned, in hospital spaces [15]. Accordingly, the cognitiveemotional effects of architecture have been addressed through different approaches and, more recently, through neuroscience. This novel, complex transdisciplinary nature of neuroarchitecture make it important to review its progress. However, although reviews have been undertaken of the application of neuroscience to other arts, such as dance [16] to aesthetics [17] and to architectural aesthetics [18], and more recently to compile findings on the effects of architecture, as measured by neurophysiological recordings [19-22], the authors' found no previous study that reviews the application of neuroscience to architecture (sometimes referred to as "built space") to study its cognitive-emotional dimension in a holistic and contextualised way (for which it is necessary to incorporate its precursor approaches, in a complementary way for the vision of some authors in this respect [23]). The objective of this article is to present a scoping review of neuroarchitecture and its precursor approaches. This type of literature review is aimed at mapping the broad areas in which a discipline is based.

In this sense, it is worth highlighting the shared ground between architecture, art, and aesthetics, which means that the results of the latter two may be, in some way, transferable to the former (for example, much of what has been studied on colour or geometry). Tackling this type of review requires a broad and interrelated perspective, which is characteristic of scoping reviews [24]. This is especially useful in the case of disciplines that are complex [25] and have not previously been reviewed at this level, like neuroarchitecture.

To address this broad objective, the following sub-objectives were set: (a) to provide a global vision of related scientific production, showing the trends of the different approaches in terms of type and date of publication, (b) to expose the need to investigate the impact of architecture on people, (c) to synthesise the main precursor approaches of neuroarchitecture to study the cognitive-emotional dimension of architecture, (d) to overview the progress of tools and methods in neuroscience and virtual reality, on which the new discipline is based, (e) define the state of-the-art application of neuroscience to the field of art and aesthetics, due to its similarity with architecture, and (f) to describe the main context, lines of research, and specific results of the application of neuroscience to architecture. In addition, the current status of the discipline is discussed. Therefore, a literature review was conducted.

\section{Materials and Methods}

Literature reviews examine articles to provide further knowledge about topics [26,27]. There are various types. The present work was tackled by means of a scoping review [28]. This strategy aligns with alternatives to present a broad perspective on complex issues involving heterogeneous sources [29]. In addition, this leads to highly explanatory articles [30] that update professionals from different fields [31]. These updates of the stateof-the-art applications are essential to support the development of the neuroarchitecture discipline. Overall, preventative measures were taken to avoid biases, using a rigorous and transparent protocol [32]. Denyer and Tranfield's proposals [33] were used to structure the methodology: (1) formulation of objectives, (2) locating studies, (3) selection of studies, (4) analysis and synthesis, and (5) the presentation of the results. All the phases are detailed (Figure 1). The objectives of the study are described in the "Introduction" section. The PRISMA (Preferred Reporting Items for Systematic Reviews and Meta-Analyses) guidelines [34] for systematic reviews were followed for the location and selection of the studies. 


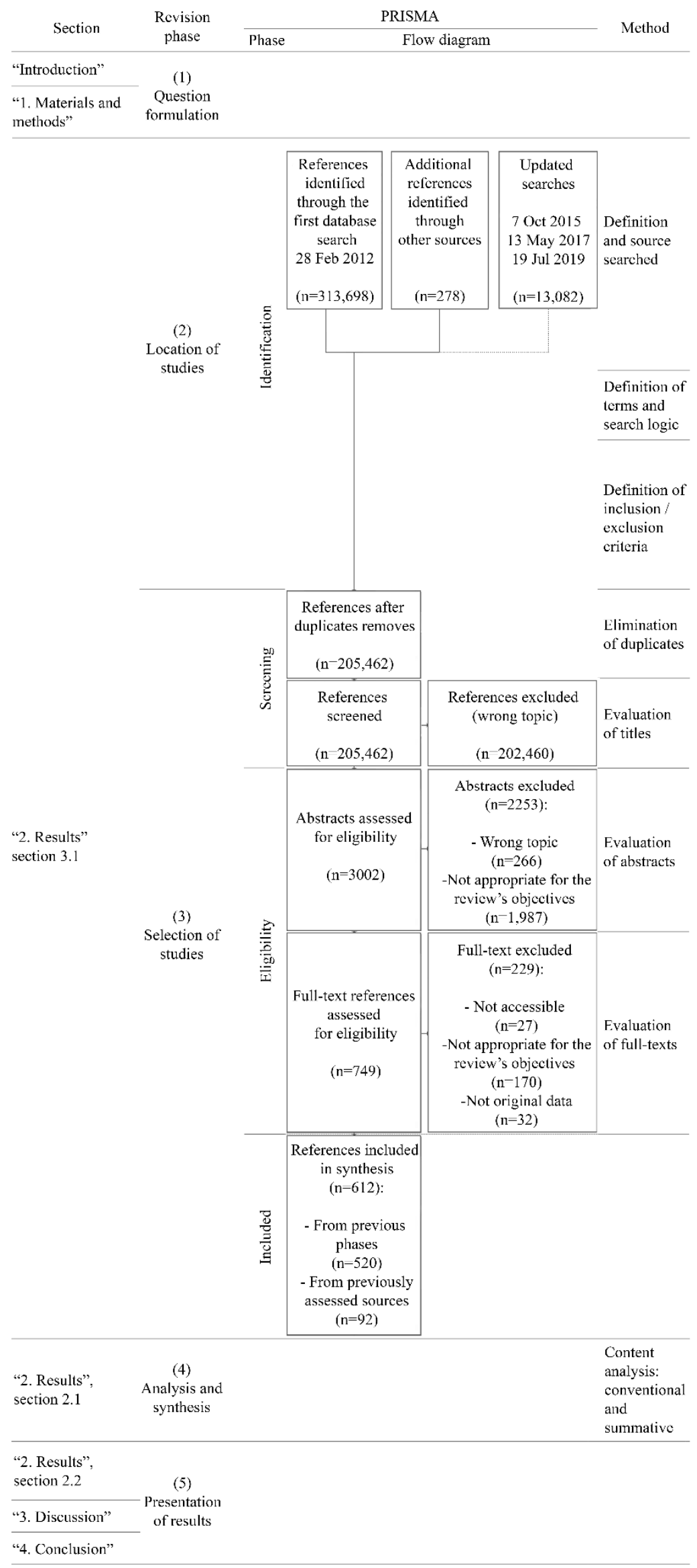

Figure 1. Expository and methodological structure, the PRISMA flow diagram, and its methods. 
The studies were located through searches of various sources. First, the studies were found in publishers' electronic databases (Avery index to architectural periodicals, Cogprints, Elsevier, Emerald, IEEE, NDLTD, PsycINFO, PubMed/Medline, Springer, Taylor \& Francis, Urbadoc, and Wiley) and repositories (Dialnet, SciELO, Google Scholar). Second, other reference lists exist, but they contain only redundant information, including content already provided by the first lists searched: Academy of Neuroscience for Architecture (https://www.anfarch.org/research/recommended-reading), Neuroscience+Architecture (http://dilab.uos.ac.kr/neuroarch/), and International Network for Neuroaesthetics (https://neuroaesthetics.net/books, and https://neuroaesthetics.net/papers). To keep the data updated, all searches were carried out four times between 28 February 2012 and 19 July 2019 (see "location of studies" in Figure 1). The same search terms and criteria were used throughout. It is worth highlighting some aspects. Regarding terminology, due to architecture's artistic and aesthetic impacts, the following concepts were considered: (architecture * OR spa * OR urban * OR "town planning") AND (neuroscien * OR percept * OR emoti * OR cogniti * OR affect *) OR neuro?architectur *; where "*" denotes truncation and "?" any character. Three criteria were stablished: language, publication category, and study type. The language criterion was that the search was to be conducted in English, Spanish, German, and Italian. This involved repeating the process with translations of the various terms. The publication-type criterion was three-fold. The most useful sources for literature reviews are usually peer-reviewed journals and conference papers [35]. Reference books were added to help address sub-objectives $a, b$, and c. It should be noted that, within these types of publications, no discard criteria were considered for indications of publisher quality. Thus, the suitability of references for this review was assessed independently throughout the selection process detailed below. The third criterion was that the studies had to be human-based. Given that much neuroscientific research is animal-based, this represented a significant restriction. It should be noted that, due to the temporal diversity of the approaches involved in sub-objective $c$, filtering by date of publication was not applied. The bibliographic references of the works retrieved were also reviewed. Therefore, these references were not localised using the above terms and language criteria. The saturation point was assumed to have been reached when most of the references were found to be redundant.

The selection process followed the bibliographic search. This consisted of four sequential actions: (1) elimination of duplicates, using Excel (http:/ / www.microsoft.com/excel) and Mendeley (http:/ / www.mendeley.com) software, (2) screening to evaluate relevance of the titles, and to make the final decision on inclusion, (3) abstract evaluation, and (4) full-text evaluation. Regarding the latter action, it should be noted that the criterion of "not appropriate for the review's objective" refers to information that is irrelevant or was not considered to be of quality judging by its overall content (discarding, among other references, a number of bachelor's or master's degree final projects), but was not adequately filtered at the abstract stage. The criterion of "not original data" refers to information that is redundant, or for which more representative information has been found in another article by the same authors (Figure 1). All the actions were centralised, to avoid mismatches in such a comprehensive reference base. The sequence made it possible to eliminate the references that did not strictly contribute to achieving the review's objectives.

Subsequently, the information selected was analysed and synthesised. Several methods are available [36]. The content analysis synthesis framework was selected due to its ability to interpret content [37] and adapt to the heterogeneous nature of reviews [38]. Two approaches were followed. The first is to categorise and group the information we undertook as a "conventional content analysis". The second is to recalculate and compare the information we undertook as a "summative content analysis". The conventional content analysis was undertaken following Reference [39], which identified relevant categories. The summative content analysis was structured in two phases. The first is through compiling the neurophysiological and design aspects, and the second is by grouping these aspects. This latter analysis resulted in summary tables. Collecting the effects of different 
design variables can be useful for different objectives within the design and study of the cognitive-emotional dimension of the architecture. For example, in decision-making prior to experimental development (to consider variables that may influence the human response, and, among other actions, to choose the appropriate sample), to guide the analysis (to bring forward brain areas on which to focus data processing, among other actions), and even directly in design (given that some of these questions can be understood as design guidelines). A qualitative analysis software, Atlas.ti (https: / / atlasti.com), was used due to the support it offers to reviews [40]. Three researchers, who are specialists in architecture, behavioural sciences, and neuroscience, independently carried out analyses. The varied profiles of the researchers helped address the heterogeneous nature of the references and reduce the effect of possible professional deformation. The analyses were shared and discussed until consensus was reached. This gives greater reliability to the findings [41,42]. The content obtained from the analyses, which was focused on meeting the sub-objectives, was organised into appropriate sections.

\section{Results}

This section synthesises the proposed sub-objectives.

\subsection{Classification of References and Their Descriptive Analysis}

The process identified 612 references that fulfilled the search criteria. A total of 327,058 were originally identified, with 289,146 from electronic databases, 37,635 from repositories, and 278 from reference lists (Table 1 ).

Table 1. Number of references identified in each source.

\begin{tabular}{|c|c|c|}
\hline Source Type & Source & Number of References \\
\hline \multirow{12}{*}{$\begin{array}{c}\text { Database } \\
(\mathrm{N}=289.145)\end{array}$} & Springer & 259,121 \\
\hline & NDLTD & 10,962 \\
\hline & PubMed & 5609 \\
\hline & Elsevier & 3438 \\
\hline & Taylor \& Francis & 3209 \\
\hline & IEEE & 2416 \\
\hline & Avery & 1949 \\
\hline & Wiley & 1523 \\
\hline & Emerald & 453 \\
\hline & Reference Lists & 278 \\
\hline & PsvcINFO & 178 \\
\hline & Cogprints & 9 \\
\hline \multirow{3}{*}{$\begin{array}{l}\text { Repositories } \\
(\mathrm{N}=37.635)\end{array}$} & Google Scholar & 36,249 \\
\hline & Dialnet & 711 \\
\hline & ScieLo & 675 \\
\hline \multirow{4}{*}{$\begin{array}{l}\text { Reference lists } \\
\qquad(\mathrm{N}=278)\end{array}$} & $\begin{array}{c}\text { Academy of Neuroscience for } \\
\text { Architecture }\end{array}$ & 69 \\
\hline & Neuroscience + Architecture & 41 \\
\hline & $\begin{array}{c}\text { International Network for } \\
\text { Neuroaesthetics }\end{array}$ & 168 \\
\hline & Total & 327,058 \\
\hline
\end{tabular}


Of the 205,462 references remaining after duplicates were removed, only 520 were included after a full-text search. In addition, 92 references were added by following a review of the reference bibliography. Of the 612 references, 130 are books, 31 are book chapters, 380 are journal papers, 55 are conference papers, 6 are posters, and 10 are of other natures. Figure 2 presents the proportions chronologically.

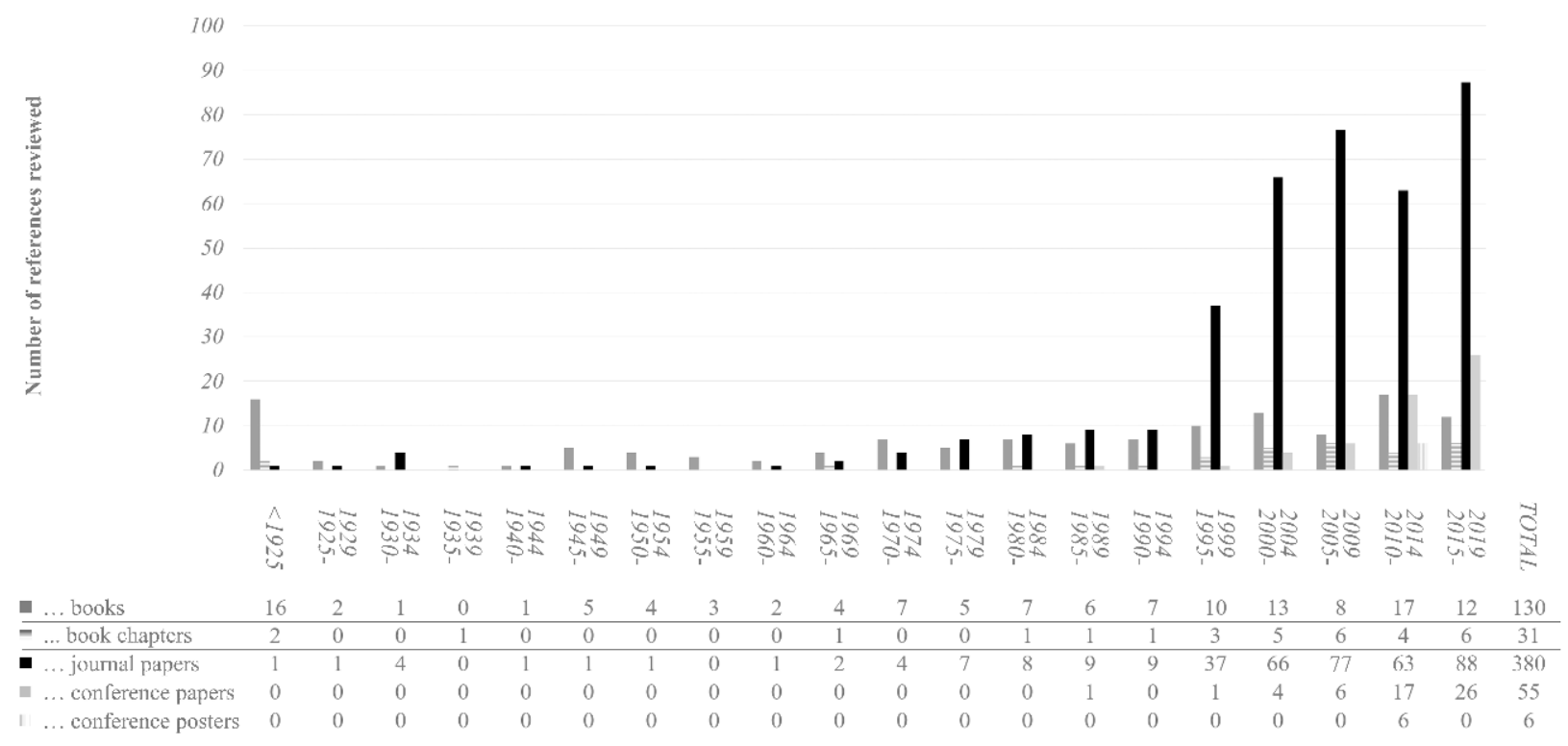

Figure 2. Number of references included, based on type and publication date.

In terms of focus, 141 references of the 612 references explicitly examine the application of neuroscience to architecture. The remaining 471 focus on the precursor approaches to the cognitive-emotional study of architectural space. Two aspects are remarkable about the neuroscience in architecture approach references. First, more references might have been expected, but this can be explained by the relatively recent emergence of the topic. Most were published after 2000 and the trend seems to indicate an increase in the next few years. The second aspect focused on the high volume of recently published books. Regarding the publication dates, only first editions were considered. In addition to references that explicitly address the issue, the others were considered relevant because they mentioned, or addressed topics related to, the review's sub-objectives.

The information in the references was categorised following the previously mentioned methodology. Each reference was able to satisfy more than one category. The categories and sub-categories are shown in Table 2. This organisation serves as a structure for the rest of the results section (sub-objectives $b$ to $f$ ). In this sense, Figure 3 provides a map of the general contents of this article.

Figure 4 provides temporal information about the sub-category references relating to approaches of the cognitive-emotional dimension of architecture. The following should be noted: (1) the different approaches that have addressed the human-space relationship have enjoyed moments of greater popularity, and (2) neuroscience was applied to architecture later than to art and aesthetics. Both aspects suggest that including all the sub-categories helps address the issues that motivate this review. 
Table 2. Categories and sub-categories linked to the references.

\begin{tabular}{|c|c|}
\hline Category & Sub-Category \\
\hline \multicolumn{2}{|l|}{$\begin{array}{l}\text { 1. The impact of architecture on human beings } \\
\text { and directly associated research }\end{array}$} \\
\hline \multirow{6}{*}{$\begin{array}{l}\text { 2. Base approaches to the cognitive-emotional } \\
\text { dimension of architecture }\end{array}$} & 2a Geometry \\
\hline & 2b1 Space phenomenology \\
\hline & 2b2 Geographical experience \\
\hline & 2c1 Philosophy \\
\hline & 2c2 Environmental psychology \\
\hline & 2c3 Evidence-based design \\
\hline \multirow{3}{*}{ 3. New architectural study and practise tools } & 3a Neuroscience \\
\hline & 3b Virtual reality \\
\hline & $\begin{array}{l}\text { 3c Combined neuroscientific and virtual reality } \\
\text { technologies }\end{array}$ \\
\hline $\begin{array}{l}\text { 4. The cognitive-emotional dimension of } \\
\text { architecture through neuro-aesthetics }\end{array}$ & $\begin{array}{l}\text { 4a Neuroscience and psychology in art and } \\
\text { aesthetics }\end{array}$ \\
\hline 5. Neuroscience in architecture & \\
\hline
\end{tabular}

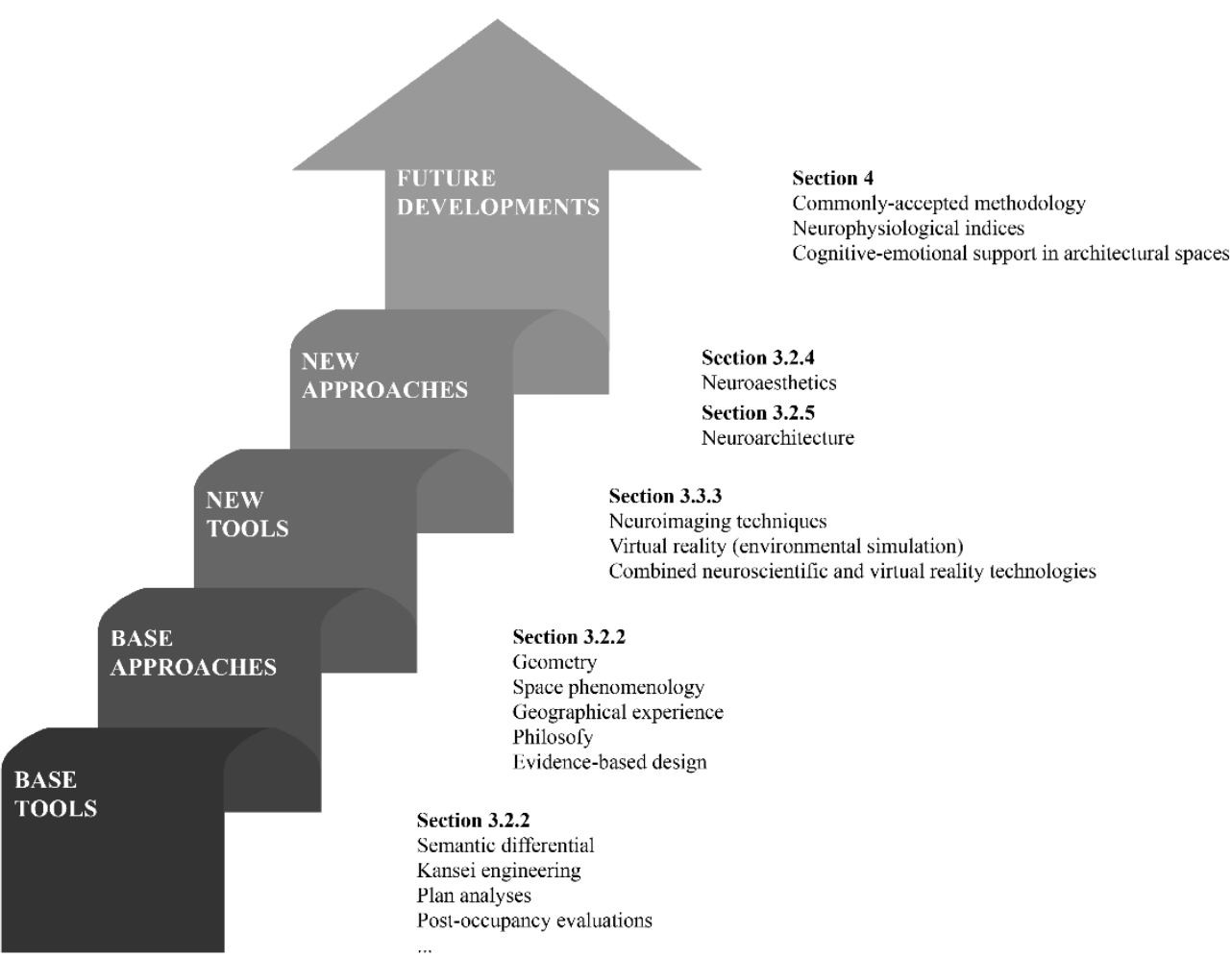

Figure 3. Expository structure and key-concepts map of the paper. 


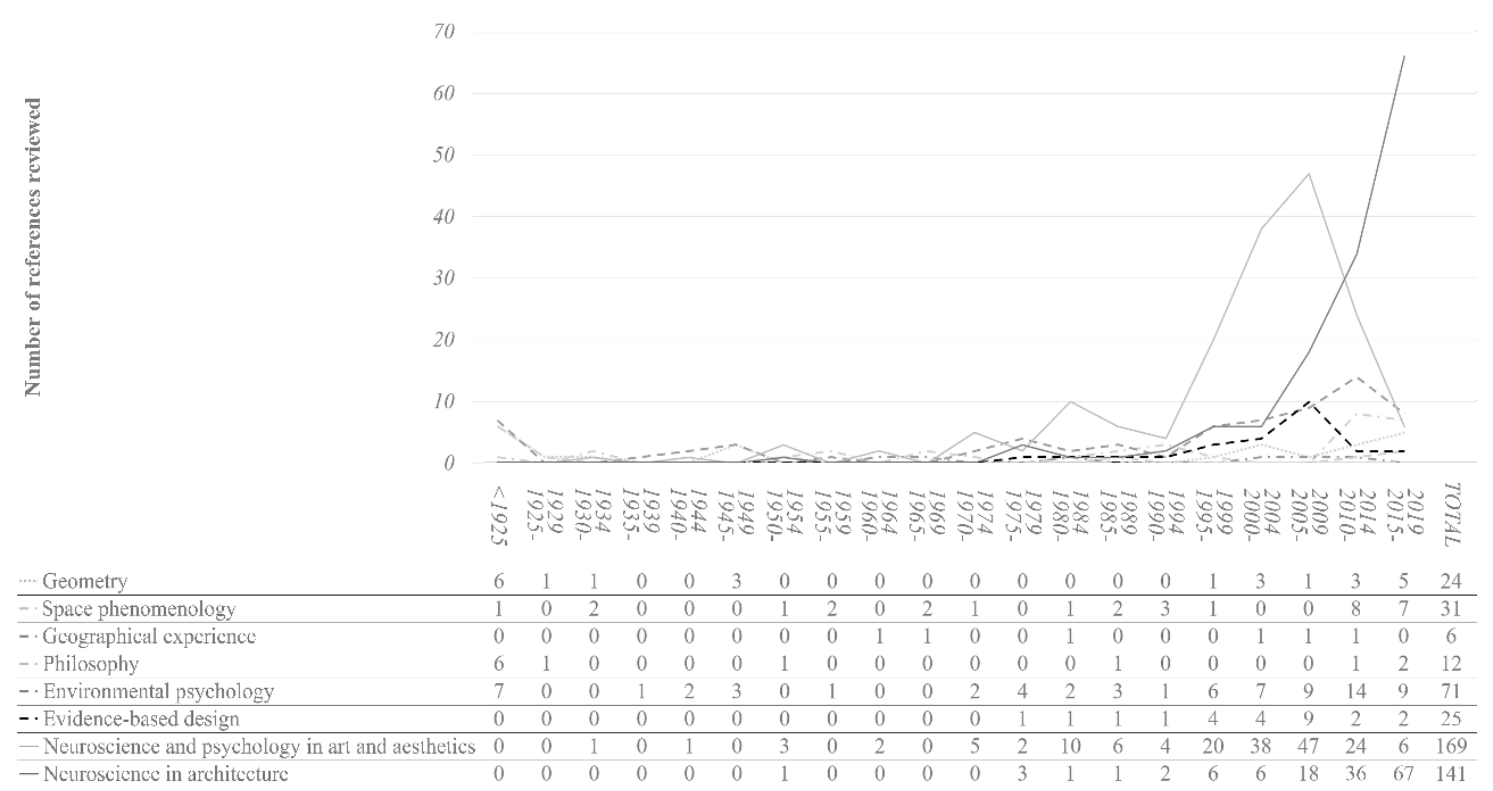

Figure 4. Number of references included, grouped by the categorisation of the approaches to the cognitive-emotional dimension, and date of publication.

\subsection{Holistic Framework of the Issue}

This issue comprises various topics. Addressing it requires a holistic approach. The expository sequence follows the structure shown in Table 2.

\subsubsection{The Impact of Architecture on Human Beings and Directly Associated Research}

The influence of architecture on human beings that acts of spatial planning have led to the current built space [43], which is our largest artifact [44,45]. Beyond its utilitarian character, architecture has complementary cognitive-emotional impacts [46]. Architecture can both elicit brain activation and modulate genetic function [47]. Consequently, changes in the environment have important impacts [48]. Its physiological and social effects should be emphasised. At the physiological level, the consequences for human development, performance, and stress are illustrative. Regarding development, a balanced environment can improve creativity [49] and cognitive function [50]. In fact, poor environmental stimulation affects brain development [51]. Environmental effects are not limited to growth stages. The environmental stimulation provoked by classroom design can improve students' performance by using cold colours [52] or smaller spaces. As to stress, some environmental elements such as noise or the absence of vegetation have been shown to have negative consequences [3,53]. Among these impacts are poorer patient recovery [54] and shorter life expectancy [5]. On the other hand, in line with the concept of a "healing environment" [55], various studies have underlined the curative benefits of architecture [56]. At the social level, it has been found that, for example, the environment can promote collectivism [57], attract candidates for posts in organisations [58], and improve citizens' sense of belonging [59] and behaviour [60]. It should be noted that the impact of environmental effects depends on the user's sensitivity [61], and non-architectural elements may also have effects [62].

Architects have been aware of this impact [63] and that, when designing architecture, experience is designed [64]. As Aalto noted, humanising architecture involves "a functionalism much larger than the merely technical" [65]. "When I enter a space, the space enters me and transforms me" [66]. These statements make it clear that addressing the cognitive-emotional state of the users is a transcendental function of architecture $[67,68]$. Despite this, the aspects most likely to be objectified have been extensively studied, and the cognitive-emotional dimension has been underexplored $[69,70]$. 
The fundamental limitation of this research is that the architectural design process is very complex [71] because the myriad of design solutions (the possible configurations of all design variables) makes it impossible to test them all. In addition, the problems that the design solutions try to resolve are diverse and vary over time (e.g., the individuals' needs from their houses can vary as they age). Although there has been extensive research into the built environment, which indicates that a certain level of analysis is possible, architectural design is infrequently, scientifically approached. Hence, the cognitive-emotional dimension of architecture has formed only a small part of the formative content [72], and the implementation of the design has been mostly based on an amalgam of practices and motivations specific to the architectural project that are part of the "designerly ways of knowing" [7].

With this as the main way of approaching the cognitive-emotional dimension of architecture, more of the objectives of architectural design have shifted to more tangible and easily quantifiable issues, such as those closely related to the constructive processes of buildings. This has been pointed out from different perspectives: "Architecture and the modern cities that have been built tend to be inhumane" [73]. Have we turned our space into an economic-cosmetic product that ignores our primitive codes [74]? The importance of the built environment cannot be underestimated. "Any future construction must be preceded by a profound study of the relationships between spaces and feelings" [75]. In this sense, new tools that show the future of neuroarchitecture have been incorporated into the traditional architectural spectrum [76].

\subsubsection{Base Approaches to the Cognitive-Emotional Dimension of Architecture}

Architectural space has been the focus of thinking and research at the cognitiveemotional level. The concept has been addressed at different times. Therefore, knowledge of these bases allows us to contextualise current developments in the application of neuroscience to architecture and to understand the context of current practice [23]. This section exposes the base approaches organized as follows: (1) geometry, (2) phenomenology of space and geographical experience, and (3) philosophy, environmental psychology, and evidence-based design. This classification acknowledges the relationships between the base approaches.

\section{Geometric Approach}

Although users might not experience the exact dimensions of proportions, they will feel the underlying harmony [77]. Architects have worked with geometric proportions to address the cognitive-emotional dimension of architecture. Thus, the geometric approach is a valid starting point from which to understand how architects work and establish bridges that can lead to the development of design tools [71].

The geometric connection between the human body and architecture has historically been addressed by two fundamental approaches, known as theomorphism and anthropomorphism. Theomorphism has existed from classical Greek architecture [78]. A well-known example is the Parthenon, fundamentally based on geometric proportions. The cognitive-emotional effect of the Parthenon's geometric proportions is similar to that sought centuries later by architects, such as Palladio [79] and Le Corbusier [80], through a series of geometric-mathematical rules. Anthropomorphism has a long tradition. Examples are found in the classical Roman world, such as temples based on the symmetry of the human body [81], and, more recently, in the Renaissance and the Baroque periods, where human bodies appeared in some buildings [82]. However, this architecture-body metaphor has been subjected to different efforts to mathematise it, which shows that these two approaches are not mutually exclusive. For example, Alberti's attempts to humanise space based on the geometry of the human body $[83,84]$. This line was exploited with Rationalism, as opposed to speaking architecture [85], which led to works by Klint [86], Bataille's anthropomorphic architecture [87], the organic architecture of Zevi [88], the close 
association with daily human needs of Smithson [89], and Niemeyer's [90] and Mollino's designs directed toward life actions [91].

Many of these geometric concepts are recurring. On the one hand, geometrical relationships found to be aesthetic, such as the nine-square pattern [92], or the golden section, have been validated experimentally [93], with the latter even using virtual reality [94] and neuroscientific bases [95]. On the other hand, the new attempts to quantify geometric properties to capture the cognitive-emotional dimension of architecture are worthy of mention. Among these are isovist analysis, the volume of space visible from a given point in space [96], and the application of artificial intelligence to distinguish formal categories, based on different features [97]. The recent mathematical-geometric analysis of architectural images is also noteworthy [98-100], through its use in architectural spaces of spatial metrics, such as edge density (number of straight and curved edges), fractal dimension (visual complexity), entropy (randomness), and colour metrics, such as hue (the dominant wavelength), saturation (the intensity of colour), and brightness (the darkness of colour). Hence, the geometric approach has not been abandoned.

\section{The Phenomenology of Space and Geographical Experience Approach}

Phenomenology is the study and description of phenomena as experienced through the senses in the first person. It is based on phenomena capable of being felt [101]. Architects have found affinities with this approach, likely because it is related to intuition.

One of the first studies into subjective space was Husserl's exposition of his ideas about the external world [102]. Heidegger continued with these influences in "Being and Time" [103], addressing the spatiality of humans and the concept of "Stimmung" (or state of mind), which is fundamental for understanding subjective space: "being impregnated by an environment". Some of the first explicit formulations were made by References [104,105], focusing on vital space. Some of the advances were compiled in "Situation" [106]. Later, the concepts of hodological space and distance including the way in which people evaluate the routes with the preference being based on subjective and objective influences, were introduced by Lewin [107], and developed by Sartre [108]. Bachelard [109] developed his space poetics, a concept widely embraced in the theory of architecture, that seeks to explain the human being's relationship with the world through poetic images. Rasmussen [110] presented a phenomenological vision of architecture, which exemplified the syncretism between phenomenology and architecture. Bollnow [111] presented concepts involved in subjective space: "[...] Unlike mathematical space, subjective space is characterised by its lack of homogeneity". This is because subjective space derives from the human's relationship with space. This has led, even, to suggestions that objective space does not exist because it is always perceived [112]. These concepts (objective space and subjective space) have been embraced by many authors in different approaches to the cognitive-emotional dimension of architecture. At the same time, the concepts have been developed in geographical experience [113], and have practical applications in urban planning [114]. Lynch work [115], which shows the influence of environmental psychology on the phenomenology of space, is representative of its beginnings [116]. More recently, Pallasmaa, influenced by previous authors, examined the phenomenology of space in architecture $[117,118]$ that claimed architecture takes account of the human biological dimension. Pallasmaa's line here is shared with Holl and Pérez-Gómez $[119,120]$. The phenomenology of space has more recently gained momentum under new approaches based on the concept of atmospheres [121,122]: quasi-things, without discrete or visible limits, that exist because of our emotional encounter with the environment $[123,124]$. Thus, the phenomenology of space and geographical experience have not been neglected.

\section{The Philosophy, Environmental Psychology, and Evidence-Based Design Approach}

Psychology addresses the behaviours and mental processes involved in its experience [125]. Its focus on space is "environmental psychology" [126,127]. Environmental psychology takes phenomenology as one of its substrates [128]. Hence, it is sometimes diffi- 
cult to distinguish them nor is it easy to discern the philosophical origins of environmental psychology [129].

It is illustrative to consider philosophical milestones. Burke [130] presented an influential philosophical exposition on aesthetics, theorising about beauty through psychophysiological concepts. Burke's ideas attracted the attention of Kant, who identified space and time as the mental structure of things that we know [131]. A series of works contributed to the expansion of psychology. Among these are Zeising, who combined geometry and psychology [132], art, physiology, and emotion linked by Friedrich Theodor Vischer [133] and Robert Vischer [134] (who coined the term "einfühlung": aesthetic empathy, the process through which humans project their emotions onto objects), Fechner, who combined physiology and psychology [135], Wundt [136] and Stumpf [137], who combined psychophysiology and philosophy. Later, Wertheimer, Koffka, and Köhler (students of Stumpf) established gestalt psychology [138]. Gestalt psychology established principles, or laws, [139] about the organisation of scenes (Table 3). Many design professionals, including architects, have often embraced these principles. It is noteworthy that Koffka [140] studied the organisation of the visual field, and Köhler developed the concept of "isomorphism" including the correlation between experience and neural activity [141] and experience as a sensory sum [142]. At this historic point, the connections between psychology and neuroscience were evident. Although subsequent studies may have rejected some of these findings, some have been accepted and the works themselves have been recognised as meritorious [143].

Table 3. Compilation of some gestalt principles.

\begin{tabular}{cr}
\hline Principle & Trend \\
\hline Totality & The whole is different from the sum (the perception of entities depends on their context) \\
\hline Dialectic & Establishing entities separate from their background \\
\hline Contrast & The entity is better perceived if there is marked contrast with its background \\
\hline Hierarchy & The greater the importance of an entity, the more hierarchical its parts are \\
\hline Birkhoff & Entities with multiple axes are more positively perceived \\
\hline Symmetry & To perceive features as symmetrical, around a centre point \\
\hline Multi-stability & Perceiving different entities from the same ambiguous experience \\
\hline Reification & To assign more information to a perception than is contained in the base stimuli \\
\hline Completion & To perceive forms as closed when they are not \\
\hline Closure & To perceive closed forms as better \\
\hline Continuity & To integrate elements of entities if they are aligned \\
\hline Good Gestalt & To integrate elements of entities if they form a regular pattern \\
\hline Invariance & To recognise entities, regardless of transformations \\
\hline Proximity & Group entities based on their proximity \\
\hline Similarity & Group entities based on their similarities \\
\hline Experience & To categorise stimuli based on previous experiences
\end{tabular}

One of the advantages of environmental psychology for addressing the cognitiveemotional dimension of architecture is its evaluation instruments. Semantic differential is among the most used [144]. This is based on the idea that a concept can acquire meaning when a sign (word) provokes the response associated with what it represents, which suggests the existence of an underlying structure. The models of Küller [145-147] and Russell \& Mehrabian [148], which described the affective-emotional states elicited by the experience of space, should be highlighted. One of its first applications was in architecture [149]. More recently, it has been used to quantify the relative importance of different design 
variables [150]. In this respect, it should be noted that some variables, such as the presence of vegetation and illumination, have been examined, but others, such as those focused on spatial geometry, have been less explored (probably, in part, because of the experimental difficulty involved in modifying them in a controlled manner). Semantic differential has also been used in the context of Kansei engineering, which is a product development method that translates the underlying structure into configurations of variables [151]. It has been applied in different contexts, including the architectural [152-154] and urban planning [153,155].

A more practical application of the tools available in environmental psychology is an evidence-based design (EBD) approach: "the process of basing decisions about the built environment on credible research" [156]. Its origins can be found in the medical field, as an extension of evidence-based medicine [157] to architectural design [158]. Illustrative are the plan analyses [159] and post-occupancy evaluations [160]. Since Ulrich demonstrated the influence of the environment on patient recovery [6], it has been widely applied in healthcare spaces [161-166]. One of the reasons that EBD is so widely used is that it is available for any organisation [167]. Various aspects have been studied. For example, some aspects include reducing pain [168] and stress [169], improving rest [170], spatial orientation [171], wandering [172], privacy and security [173], social cohesion [174], overall well-being and satisfaction [175], and the design of children-tailored environments [176]. Table 4 compiles effects generated by different design variables, according to different studies both in environmental psychology and EBD.

Table 4. Effects generated by variables or aspects of architectural design frequently studied in the environmental psychology and EBD approach.

\begin{tabular}{|c|c|}
\hline Design Variable & Effect \\
\hline \multirow{3}{*}{ Ceiling height } & High ceilings inspire freedom, low ceilings calm [177]. \\
\hline & High ceilings generate greater creativity and feelings of comfort [178]. \\
\hline & Ceiling height positively affects wayfinding [179] \\
\hline \multirow{4}{*}{$\begin{array}{l}\text { Presence of } \\
\text { vegetation }\end{array}$} & Vegetation reduces stress and anxiety [4]. \\
\hline & In parks, pleasure increases based on tree density, and arousal with weed density [180]. \\
\hline & Biophilia hypothesis: preference for natural forms [181,182]. \\
\hline & $\begin{array}{l}\text { Attention restoration theory: natural environments are restorative. Their restorative characteristics are } \\
\text { "fascination," "being away," "coherence," and "compatibility" [183]. }\end{array}$ \\
\hline \multirow{2}{*}{ Complexity } & Preference for moderate levels of complexity, similar to a savannah environment [184]. \\
\hline & $\begin{array}{l}\text { Prospect-refuge: preference for natural and built environments, which offer visual control of the } \\
\text { environment and places to hide [185-187]. }\end{array}$ \\
\hline \multirow{5}{*}{ Illumination } & Colour temperature and illuminance are interrelated with comfort [188]. \\
\hline & Natural light reduces hospital stays [189]. \\
\hline & $\begin{array}{l}\text { Light and form are interrelated: walls and ceilings influence the perception of brightness. A room appears } \\
\text { larger when it receives more indirect light [190]. }\end{array}$ \\
\hline & $\begin{array}{l}\text { Mood valence and cognitive performance alter based on light parameters: colour temperature with a less } \\
\text { negative effect on mood, improved cognitive performance, the combination of colour temperature, and } \\
\text { illuminance with better evaluation in mood, improved cognitive performance [191]. }\end{array}$ \\
\hline & Emotional states affect the perception of brightness [192]. \\
\hline \multirow{4}{*}{ Colour } & Extracted at an early stage of visual processing [193] \\
\hline & Wide variety of effects on aesthetic preferences [194]. \\
\hline & Hue and saturation are related to the emotional state [195]. \\
\hline & Warm tones have higher arousal values, and colder tones are lower [196]. \\
\hline Use & The use to which a space is put influences its psychological evaluation [197]. \\
\hline Coherence & $\begin{array}{l}\text { In natural settings, the coherence of a setting with wooden furniture is significantly greater than a setting } \\
\text { with metal furniture, but significantly less than a setting without furniture [198]. }\end{array}$ \\
\hline
\end{tabular}




\subsubsection{New Tools in Architectural Research and Practice}

The base approaches, in general, have two limitations: (1) the validity of the selected stimuli, and (2) the applicability of the evaluations. Regarding the stimuli, although representations may be valid [199], they are limited. For example, photos and videos, frequently used, offer little interactivity. This reduces virtual immersion [200] and impoverishes the experience. When environmental simulation differs from reality, the results can be distorted. Moreover, these stimuli do not allow environmental parameters to be controlled. Regarding evaluations, self-reports are prone to bias [201], as they record only the conscious aspects of human responses. This is important, given that most cognitive and emotional processes occur at the unconscious level [202]. Taking these points into account, the results must be contextualised.

Regarding new approaches to the cognitive-emotional dimension of architecture, we try to overcome these limitations. New research tools provide: (1) artificial stimuli that are more similar to physical, real stimuli (in the represented spaces), and (2) new, more objective evaluations of cognitive-emotional responses. Virtual reality (VR) is frequently used to provide stimuli. VR simulates environments in a realistic, immersive, and interactive way [203] under controlled laboratory conditions [204]. As for evaluation, neuroscience and its related technologies allow researchers to record and interpret human behavioural, physiological, and neurological reactions [205], providing high levels of objectivity [206] and continuous monitoring $[207,208]$. Although neuroscientific techniques have been available for decades, their application is currently expanding.

\section{Neuroscience}

Neuroscience focuses on the brain and nervous system [209]. On the basis that normal human brains are very similar, neuroscience has provided insights into the functioning of the nervous system [210,211]. Resorting to the brain is starting from the root [212]. Neuroscience has different areas of expertise [213]. This has allowed its results, methodologies, and tools to also have an implication on issues directly related to other disciplines. For example, cognitive neuroscience, behavioural neuroscience, neurophysiological neuroscience, and sensory neuroscience shed light on perception in general [214] and on space in particular [215]. Given neuroscience's applicability to architecture [216], the discipline can contribute to quantifying architecture's impact on humans $[217,218]$. Thus, designs that contribute to their users' quality of life can be produced $[219,220]$.

However, human nervous system studies have had few avenues to explore human brain function. They have generally been limited to examining patients with neural injuries or suffering from neurodegenerative diseases [221]. Studies into the effects of neuronal injuries on art production have followed this approach [222]. For example, it has been found that frontotemporal dementia changes musical taste [223], that damage to the amygdala impairs the identification of sad music [224], and that damage to one hemisphere causes spatial neglect on the opposite side in drawings [225-227]. Paradoxically, neuronal injuries can sometimes improve artistic skills [228-230]. Due to the paucity of this form of study, they have sometimes been considered "informative anecdotes" [17]. The clearest conclusions have only been able to be drawn after the joint analysis of cases [231].

Neuroimaging techniques open new paths. Based on the non-invasive recording of brain responses [232,233], they allow observation of the responses of healthy individuals under controlled conditions. From their first applications to art, studies have made substantial progress $[234,235]$. These techniques are essential in the exploration of the neural processes involved in art generation and appreciation. Various tools are used to obtain the recordings [236] from the central (CNS), the autonomic (ANS), and the somatic (SNS) nervous systems.

The CNS is made up of the brain and the spinal cord. The tools most commonly used to study CNS functions in living humans are functional magnetic resonance imaging (fMRI), electroencephalography (EEG), and magnetoencephalography (MEG). fMRI measures neuronal activity indirectly by detecting changes in magnetic properties related to blood 
flow [237]. Although its temporal resolution is poor, fMRI yields better spatial resolution and deep structure identification than other methods. fMRI has been used to study aspects such as memory [238]. EEG measures electric field fluctuations due to the ionic currents generated by neuronal activity in the brain, mainly the cortical areas because they are the most superficial [239]. The analysis of the recordings generally involves the classification of power spectral densities within defined frequency bands, on the basis that the brain is made up of different networks that operate at its frequency, and the relationships between these networks [240]. The high temporal resolution of EEG allows the analysis of stereotyped fluctuations generated by discrete stimuli [241]. EEG has been used to study, for example, mental workload [242]. In contrast, MEG measures the magnetic fields generated by the ionic current [243]. Although its infrastructure has drawbacks (MEG equipment is not wearable or portable), the skull and scalp distort the magnetic fields less than the electric. This advantage makes MEG a powerful tool for exploring the functions of deeper cellular structures, such as the hippocampal's role in cognition [244]. In parallel, it is possible to stimulate brain areas using transcranial magnetic stimulation (TMS), which is a technique used in various fields [245].

The ANS, which is part of the peripheral nervous system, controls involuntary actions. The tools most commonly used to study ANS function monitor electrodermal activity (EDA, called Galvanic Skin Response, or GSR), heart rate variability (HRV), and pupillometry. EDA measures variations in electrodermal properties, particularly electrical conductivity [246]. Sudomotor activity is related to sympathetic nervous system activity [247], so it is appropriate for tracking arousal [248]. EDA has been used to study attention [249]. HRV measures the variation in time between heartbeats [250]. HRV measurements are generally grouped into time-domain and frequency-domain with both having clinical and cognitive-emotional significance [251]. It has been used to study issues such as stress [252]. Pupillometry is the measurement of the diameter of the pupil of the eye [253]. Although the pupil diameter is directly affected by a light level, it has also been related to arousal [254] and cognitive load [255]. While ANS activity has been considered insufficient to study the nuances of emotion [256], it has more recently been favoured [257].

The SNS is the part of the peripheral nervous system associated with voluntary movement. Eye tracking and electromyography (EMG) are commonly used tools. Eye tracking is the measure of gaze movement [258]. Eye movements, to an extent, identify the focus of our attention (voluntary and involuntary), and are influenced by cognitiveemotional states [259]. Various metrics are used to measure eye movements, based on the parametrization of the movements [260]. For example, eye tracking has been used to study engagement [261]. EMG measures the electrical activity of the muscles [262]. To measure facial expressions related to emotion [263], recordings are usually made of the corrugator supercilii [264] and the zygomaticus major [265], which are muscles strongly influenced by emotional valence [266]. Thus, EMG has been frequently used to study basic emotions [267]. There is, in addition, automatic image-based facial expression recognition (facial coding). Some architectural studies have applied physical eye tracking [268-270] and eye tracking simulated by software [271] and facial coding [272].

Given the complexity of neural activity, these tools are insufficient to fully explain it. However, they offer information about its bases and are compatible with other approaches. They make a contribution that, in architecture, recalls the optimism that Frampton attributed to the technique to "replace the devalued motives [...] of our environment and turn it into an authentic place" [273].

\section{Virtual Reality}

Environmental simulations are representations of actual environments [274]. There are different types [275]. VR generates interactive real-time computer representations that replace the visual information normally provided by the physical world and create the feeling of "being there" [276]. It is possible, though seldom done, to create virtual representations using other sensory channels. This type of stimulation is especially interesting. 
For example, head transfer function (a response to how a sound emitted from a point is received after the sound arrives at the listener) is involved in how we perceive physical and virtual environments [277]. Hapticity plays an important role in the supramodal experience of architecture [278], and smell has important cognitive-emotional effects in certain situations, such as stress reduction [15].

Various devices are used to reproduce VR formats. It is common to classify them according to immersion: the degree to which the hardware isolates the user from the physical world [279]. Thus, there are non-immersive devices, such as computer monitors, semi-immersive devices, such as the cave automatic virtual environment (CAVE), and fullyimmersive devices, such as head-mounted displays (HMDs). Greater immersion generates a greater sense of presence, that is, the user's perceptual illusion of non-mediation $[280,281]$. Greater presence also involves the allocation of more brain resources for cognitive/motor control [282]. Although non-immersive devices inherently offer the advantage of collaborative viewing [283], the majority of current interests focus on the other two types of device and HMDs are now within reach in terms of usability and affordability [284]. This increasing popularisation has contributed to VR being used in other fields.

In architecture, VR has given rise to an explosion of applications [285]. VR allows us to modify variables in the same space in isolation and record human interaction with the environment, quickly and at low cost [286]. VR, thus, is an optimal tool for evaluating human responses to architecture [287] at both behavioural and neurophysiological levels [288,289] and even its cartographic representation [290]. For example, it has been used to study relationships between experience and space variables [291], facilitate design decision-making [292], and assess accessibility [293,294] and orientation inside buildings [295], including in emergency situations [296]. Thus, VR provides knowledge beyond that provided by the physical world.

The interactivity inherent in VR gives rise to a fundamental aspect that should be addressed: navigation. Two components of navigation are usually discussed: wayfinding and travel [297]. Wayfinding is the cognitive process of establishing a route [298,299]. It has been suggested that wayfinding performance in virtual environments is poorer than in physical environments [300,301]. The travel component, related to the task of moving from one point to another, has been found to be strongly affected by the navigation metaphor used to perform the navigation. Many navigation metaphors, classified as physical or artificial, are available. Physical metaphors are varied. For example, room-scale based metaphors, such as real walking inside a physical space, is the most naturalistic metaphor but is highly limited by the physical tracked area [302]. Motion-based metaphors, such as walking-in-place, is a pseudo-naturalistic metaphor where the user performs virtual locomotion, while remaining stationary (e.g., moving the hands), to navigate [303], or redirected walking, known as a metaphor where users perceive they are walking while they are unknowingly being manipulated by the virtual display, which allows navigation in an environment larger than the physical tracked area [304]. Artificial metaphors facilitate direct movements using joysticks, keyboards, or similar devices [305]. Among these are teleportation-based metaphors, which allow users instantaneous movement to a selected point [306]. There is no consensus as to which is the most appropriate [307]. Since navigation can radically condition space perception and, therefore, subsequent human responses, it is a key aspect that needs to be considered.

However, VR does have some problems. These are generally of a technical nature, such as the previously discussed navigation [308,309], level of detail [310], and negative symptoms and effects [311]. In architecture, an important limitation is that, although VR can be combined with auditory and tactile stimulation [312], the richness of the experience is limited [313]. A simulation will always be a simulation [314], an abstraction of a complex reality [315], and, thus, VR cannot reproduce physical environments [316]. Therefore, studies that employ VR must be validated in physical environments [317-319]. Despite these drawbacks, synthetic environments have been shown to elicit behavioural responses similar to physical environments [320] and VR has its uses in various fields [321] and, in 
particular, in architecture. It is a tool for architects and cognitive scientists interested in spatial perception and cognition.

\section{Combined Neuroscientific and Virtual Reality Technologies}

Neuroscience and VR can be combined [322]. This combination allows researchers to develop virtual environments and record the neurophysiological and behavioural responses of experimental subjects [323-328]. It has been suggested that this combination is more rigorous than research in physical settings using self-reports [329]. This is attractive for neuropsychological research [330] and architecture [331]. Thus, combined VR/neuroscience techniques are increasingly being used to examine the psychological [332] and neural bases of different aspects of the human-space relationship [333]. The techniques are being used in visuomotor [334] and spatial learning [335], evaluations of cognitive rehabilitation [336], assessments of social situations [337], training in simulated environments [338], quantification of sense of presence [339], and studies exploring the neurophysiological foundations of cognitive-emotional states, such as arousal [340-343], stress [344-347], and fear [348,349]. The combined approach allows us to evaluate the cognitive-emotional influence of architecture from a new perspective [350].

\subsubsection{The Cognitive-Emotional Dimension of Architecture Measured} through Neuro-Aesthetics

Neuroscientific and virtual reality technologies have been extensively used in experiments in the related fields of art and aesthetics. They have provided a very valuable source of results and methodologies. The discipline derived from applying neuroscience to aesthetics has been called "neuro-aesthetics". Neuro-aesthetic research is an example of how technologies can contribute to the study of art [351,352] and, since architecture shares lines of action with art and aesthetics, understanding the most illustrative innovations that have taken place in art and aesthetics represents an important new knowledge source for architecture [353]. However, although a certain degree of extrapolation could be presumed, it should be noted that the current state of development of neuroarchitecture does not yet make it possible to determine to what extent extrapolation is possible. Below, we discuss some landmarks that have been considered of special importance and affinity with architecture, considering contributions from different artistic contexts and, therefore, sensory modalities.

Psychology has developed various levels of analysis over the last century [354]. Some of these analytical levels have focused on the "objective" and "subjective" aspects that influence the aesthetic experience [93].

Among the "objective" aspects related to the characteristics of objects are: (1) symmetry, (2) centre, (3) complexity, (4) order, (5) proportion, (6) colour, (7) context, and (8) processing fluency. Table 5 presents some effects and, where appropriate, related neurophysiological activity (RNA) and their Brede Database WOROI (a hierarchically structured directory of brain structures) codes. Many of these objective aspects have been approached intuitively, from different artistic disciplines, but applying a psychological approach provides new knowledge that can be of interest both to artists and researchers. For example, symmetry, which has been used frequently from early times in some architectural trends and styles, has been associated with faster cognitive processing of stimuli, but also with a certain aesthetic rigidity. Other less studied aspects are typicity [355] and semantic content, as opposed to formal qualities [356] and style [357]. Many of these aspects are grouped in Ramachandran and Hirstein's [358] theory of aesthetic experience. This conceptualises eight principles: peak shift effect, isolating single clues, perceptual grouping, contrast, perceptual problem solving, generic viewpoint, metaphor, and symmetry. 
Table 5. Effects generated by the "objective" aspects frequently studied in psychology applied to art. The table incorporates some points about the neuronal activities involved (the nomenclature of the sources is followed, and WOROI codes are added).

\begin{tabular}{|c|c|c|c|}
\hline Objective Aspect & $\begin{array}{c}\text { Effect/Related Neurophysiological } \\
\text { Activity (RNA) }\end{array}$ & Appreciation & WOROI \\
\hline \multirow{8}{*}{ Symmetry } & $\begin{array}{c}\text { Symmetry and asymmetry can evoke } \\
\text { emotional states [359]. }\end{array}$ & $\begin{array}{l}\text { Between both there is a wide spectrum of } \\
\text { compositions [360]. }\end{array}$ & \\
\hline & \multirow{3}{*}{ General preference for symmetry [361]. } & In graphic patterns [362]. & \\
\hline & & In faces $[363,364]$. & \\
\hline & & Traditionally linked to beauty [365]. & \\
\hline & Various artistic currents have used this [358]. & $\begin{array}{c}\text { A certain tendency to break it to avoid } \\
\text { rigidity [366]. }\end{array}$ & \\
\hline & \multirow{2}{*}{$\begin{array}{l}\text { Detected rapidly in different } \\
\text { circumstances [367]. }\end{array}$} & Including in art [368]. & \\
\hline & & $\begin{array}{l}\text { May be due to a cognitive propensity to } \\
\text { process [369]. }\end{array}$ & \\
\hline & $\begin{array}{l}\text { RNA: sustained posterior activity, } \\
\text { spontaneously during its analysis [370]. }\end{array}$ & & 21 \\
\hline Centre & $\begin{array}{l}\text { The geometric centre of a visual work has } \\
\text { special importance [371]. }\end{array}$ & $\begin{array}{l}\text { The "colorimetric barycentre" of a painting } \\
\text { corresponds closely to its geometric } \\
\text { centre [372]. }\end{array}$ & \\
\hline \multirow[t]{2}{*}{ Colour } & $\begin{array}{l}\text { The colour of light has various influences at } \\
\text { neurophysiological and behavioural } \\
\text { levels [373]. }\end{array}$ & & \\
\hline & $\begin{array}{l}\text { RNA: Prefrontal cortex activity is related to } \\
\text { coloured objects [374]. }\end{array}$ & & 22 \\
\hline \multirow{4}{*}{ Complexity } & $\begin{array}{l}\text { Has great weight in aesthetic } \\
\text { judgement [375]. }\end{array}$ & & \\
\hline & $\begin{array}{c}\text { An aspect that lacks uniqueness [376], a part } \\
\text { of other variables. }\end{array}$ & $\begin{array}{l}\text { Has been combined with aspects such as } \\
\text { symmetry [369]. }\end{array}$ & \\
\hline & $\begin{array}{l}\text { Preference for moderate levels of complexity } \\
\qquad[377,378] \text {. }\end{array}$ & $\begin{array}{l}\text { Its effects depend on the level of adaptation } \\
\text { of the observer [379]. }\end{array}$ & \\
\hline & $\begin{array}{l}\text { Preference in general for low fractal } \\
\text { dimensions, between } 1.3 \text { and } 1.5 \text { [380], and } \\
\text { for medium-high in architecture [381]. }\end{array}$ & Affects EDA recording [382]. & \\
\hline \multirow{3}{*}{ Order } & \multirow{3}{*}{$\begin{array}{l}\text { Can improve the reading of a complex } \\
\text { pattern and, therefore, its aesthetic } \\
\text { evaluation, but a lack of complexity evokes } \\
\text { monotony, and complexity without order } \\
\text { evokes chaos [166]. }\end{array}$} & $\begin{array}{l}\text { Some current architectural works are proof } \\
\text { of this imbalance, this being one of the } \\
\text { reasons for the increase in written } \\
\text { explanations [165]. }\end{array}$ & \\
\hline & & $\begin{array}{l}\text { Pattern recognition as a factor with a high } \\
\text { impact on natural selection [383]. }\end{array}$ & \\
\hline & & $\begin{array}{l}\text { Visual brain understood as a } \\
\text { pattern-recognition device [384]. }\end{array}$ & \\
\hline Proportion & $\begin{array}{l}\text { Certain ratios, such as the golden section, } \\
\text { generate greater preference [93]. }\end{array}$ & & \\
\hline
\end{tabular}


Table 5. Cont.

\begin{tabular}{|c|c|c|c|}
\hline Objective Aspect & $\begin{array}{c}\text { Effect/Related Neurophysiological } \\
\text { Activity (RNA) }\end{array}$ & Appreciation & WOROI \\
\hline \multirow{6}{*}{ Context } & \multirow{3}{*}{$\begin{array}{l}\text { Important when making general perceptual } \\
\text { judgments }[385,386] .\end{array}$} & $\begin{array}{l}\text { And when making aesthetic judgements in } \\
\text { particular }[387,388] .\end{array}$ & \\
\hline & & $\begin{array}{c}\text { The representation of the context of an } \\
\text { object in terms of its relationships to other } \\
\text { objects or through a statistical summary of } \\
\text { the scene [389]. }\end{array}$ & \\
\hline & & $\begin{array}{l}\text { A rapid affective precognitive assessment } \\
\text { of the environment is undertaken, based on } \\
\text { elements of the scene [390]. }\end{array}$ & \\
\hline & $\begin{array}{l}\text { RNA: memory subsystems may be altered by } \\
\text { context [374]. }\end{array}$ & & \\
\hline & $\begin{array}{l}\text { RNA: the para-hippocampal cortex } \\
\text { participates in contextual associations [374]. }\end{array}$ & & 65 \\
\hline & $\begin{array}{l}\text { RNA: the retro-splenial cortex participates in } \\
\text { contextual associations [391]. }\end{array}$ & & 310 \\
\hline \multirow{4}{*}{$\begin{array}{l}\text { Processing } \\
\text { fluency }\end{array}$} & \multirow{2}{*}{ Clear images are processed more easily [358]. } & $\begin{array}{l}\text { Contributes to making images more } \\
\text { preferred }[392,393] \text {. }\end{array}$ & \\
\hline & & $\begin{array}{l}\text { However, to distinguish certain basic } \\
\text { scenes (such as indoor vs. outdoor), very } \\
\text { crude information might be sufficient [394]. }\end{array}$ & \\
\hline & $\begin{array}{l}\text { Ambiguity is an inherent aspect of the } \\
\text { process, relates to openness to multiple } \\
\text { interpretations [395]. }\end{array}$ & & \\
\hline & $\begin{array}{l}\text { RNA: The left fusiform gyrus seems to } \\
\text { participate more in semantic processing, and } \\
\text { the right fusiform gyrus participates in visual } \\
\text { recognition [396]. }\end{array}$ & & 133,134 \\
\hline
\end{tabular}

Among the "subjective" aspects, related to personal factors, are: (1) emotional state, (2) familiarity and novelty, (3) pre-classification, and (4) others of a social nature. Table 6 summarises some effects. These aspects complement the objective aspects, and play an important role [397]. Subjective aspects have been addressed using different evaluation instruments, which highlights the variety of psychological tools available for application to art. For example, tools such as fMRI and EEG have been recently used to study the neuro-behavioural effects of familiarity and novelty of stimuli, whose impacts on aesthetic judgement were already known at the psychometric level. In fact, neuroscience is advancing rapidly [398]. Since the first event-related potentials in aesthetic judgment studies were published in 2000, a large number focused on aesthetics in painting have appeared [399]. Later, specific aspects of painting and other forms of artistic expression were addressed [400]. A growing trend exists that is revealing the neurophysiological bases of the (previously discussed) objective and subjective aspects that influence the aesthetic experience. 
Table 6. Effects generated by the "subjective" aspects frequently studied by psychology applied to art. The table incorporates some points about the neuronal activities involved (the nomenclature of the sources is followed, and WOROI codes are added).

\begin{tabular}{|c|c|c|c|}
\hline Subjective Aspect & $\begin{array}{l}\text { Neurobehavioural Effect/Related } \\
\text { Neurophysiological Activity (RNA) }\end{array}$ & Sub-Effect/Appreciation & WOROI \\
\hline \multirow[t]{2}{*}{ Emotional state } & Affects aesthetic judgement [401]. & $\begin{array}{l}\text { Influences the way a work of art is } \\
\text { processed [402]. } \\
\text { Tendency to memorise and associate } \\
\text { information consistent with the } \\
\text { emotional state of the subject [403]. }\end{array}$ & \\
\hline & Affects judgement of distance & & \\
\hline \multirow{6}{*}{ Familiarity-Novelty } & \multirow[b]{2}{*}{ Affects aesthetic judgement $[377,404-406]$. } & $\begin{array}{l}\text { Objects are processed more efficiently in } \\
\text { a familiar context }[407,408] .\end{array}$ & \\
\hline & & $\begin{array}{c}\text { For a work to be attractive it must be } \\
\text { located in a specific range of the } \\
\text { "novelty/familiarity" ratio [366]. }\end{array}$ & \\
\hline & $\begin{array}{l}\text { RNA: the frontal lobe and the right } \\
\text { hemisphere participate in novelty } \\
\text { processing [366] }\end{array}$ & & 18,707 \\
\hline & $\begin{array}{l}\text { RNA: blood-oxygen-dependent level is } \\
\text { reduced by repeating an image [409]. }\end{array}$ & & \\
\hline & $\begin{array}{l}\text { RNA: the gamma band exhibits greater } \\
\text { activity in the inferior-temporal, } \\
\text { superior-parietal, and frontal brain areas } \\
\text { when viewing familiar than non-familiar } \\
\text { objects [410]. }\end{array}$ & & $16,168,18$ \\
\hline & $\begin{array}{l}\text { RNA: the gamma band exhibits a } \\
\text { stronger increase after } 250 \text { ms of } \\
\text { identification of familiar objects [411]. }\end{array}$ & $\begin{array}{c}\text { Related to increased activity in the } \\
\text { gamma band in the occipital [412] and } \\
\text { frontal areas, when observing ambiguous } \\
\text { objects [413]. }\end{array}$ & 26,18 \\
\hline \multirow{2}{*}{ Pre-classification } & $\begin{array}{l}\text { Previous considerations affect } \\
\text { aesthetic judgment. }\end{array}$ & $\begin{array}{l}\text { Knowing that a work of art is a forgery } \\
\text { alters both familiarity and aesthetic } \\
\text { judgements [414]. }\end{array}$ & \\
\hline & $\begin{array}{l}\text { RNA: neural activity can be modulated } \\
\text { by external influences, as with the } \\
\text { semantic labelling of scents [415]. }\end{array}$ & & \\
\hline \multirow{3}{*}{ Social: Social Status } & $\begin{array}{l}\text { Demonstrations of dominance or wealth } \\
\text { influence aesthetic judgment [416]. }\end{array}$ & $\begin{array}{l}\text { Related to activation of the } \\
\text { reward-related brain areas [417]. }\end{array}$ & \\
\hline & $\begin{array}{l}\text { RNA: reward circuitry most activated by } \\
\text { objects associated with wealth or social } \\
\text { dominance [418]. }\end{array}$ & & \\
\hline & $\begin{array}{l}\text { RNA: Knowing the economic value of a } \\
\text { product increases preference and } \\
\text { activation of the medial OFC [419]. }\end{array}$ & & 698 \\
\hline
\end{tabular}


Table 6. Cont.

\begin{tabular}{|c|c|c|c|}
\hline Subjective Aspect & $\begin{array}{l}\text { Neurobehavioural Effect/Related } \\
\text { Neurophysiological Activity (RNA) }\end{array}$ & Sub-Effect/Appreciation & WOROI \\
\hline \multirow{10}{*}{ Social: Culture } & $\begin{array}{l}\text { Modulates visual perceptual } \\
\text { processing [420]. }\end{array}$ & $\begin{array}{l}\text { Affects even basic visual aspects, such as } \\
\text { colour [421]. }\end{array}$ & \\
\hline & \multirow{5}{*}{ Related to artistic sensitivity [422]. } & $\begin{array}{l}\text { Can be developed with expertise, } \\
\text { something for which humans are perhaps } \\
\text { conditioned, given that a self-rewarding } \\
\text { experience is elicited when a work is } \\
\text { recognised [423]. }\end{array}$ & \\
\hline & & $\begin{array}{l}\text { Significant in aesthetic judgement } \\
{[424,425] .}\end{array}$ & \\
\hline & & $\begin{array}{l}\text { Behavioural differences in terms of how } \\
\text { experts and non-experts experience } \\
\text { art [426]. }\end{array}$ & \\
\hline & & Related to style-based processing [427]. & \\
\hline & & $\begin{array}{l}\text { Architectural eye tracking-based } \\
\text { studies [428]. }\end{array}$ & \\
\hline & \multicolumn{2}{|l|}{$\begin{array}{l}\text { RNA: expertise generates different } \\
\text { event-related potentials in aesthetic } \\
\text { judgment [429]. }\end{array}$} & \\
\hline & \multicolumn{2}{|l|}{$\begin{array}{l}\text { RNA: expertise generates different } \\
\text { eye-movement patterns and visual } \\
\text { memory [430]. }\end{array}$} & \\
\hline & \multicolumn{2}{|l|}{$\begin{array}{l}\text { RNA: expertise generates changes in } \\
\text { memory and perception-related } \\
\text { structures [431]. }\end{array}$} & \\
\hline & $\begin{array}{l}\text { RNA: expertise helps to execute creative } \\
\text { processes faster (considering that these } \\
\text { involve a decrease in average arousal } \\
\text { measured through EDA and EMG). }\end{array}$ & & \\
\hline
\end{tabular}

Distinctions are normally made between the neurophysiological foundations of attention, judgement, and emotion [432]. Table 7 summarises some effects. Taking attention, it has been found that visual processing occurs both in parallel and hierarchically [433], as more complex issues are gradually solved [434]. In terms of artistic judgement, there are two stages known as a general impression of works at around $300 \mathrm{~ms}$ and a deeper aesthetic evaluation at around $600 \mathrm{~ms}$ [435]. Regarding emotion, aesthetics is a complex experience that involves different affective-emotional processes that activate reward-related brain regions [436]. Reward is understood as the positive value attributed to something [437]. Hemispheric specialisation has also received attention [438]. Some studies have seemed to suggest that there are asymmetric functions in the brain hemispheres, and while they might be activated by the same stimuli, they react in different ways [439]. Thus, while two parts of the brain might be activated by the same stimuli, only one would be the final controller. However, aesthetic experience involves different aspects [440], processed through the same systems used in other areas [441]. In this sense, mirror neurons are interesting. Mirror neurons are activated both when carrying out an action and when observing it. The observers' neurons "mirror" (hence, the name) the behaviour of the individual carrying out an action, as if the observers themselves were performing it. It has been suggested that the behaviour of mirror neurons is important to social life-linked cognitive capacities, such as empathy [442], but also to the empathic understanding of art [443], and, therefore, in the specific context of architecture [444]. 
Table 7. Neurophysiological foundations of the aesthetic experience (the nomenclature of the sources is followed, and WOROI codes are added).

\begin{tabular}{|c|c|c|c|}
\hline & & Related Neurophysiological Activity & WOROI \\
\hline \multirow{6}{*}{ Attention } & \multirow{2}{*}{ Stimulus location } & Frontal eye field [445]. & 34 \\
\hline & & Cingulate cortex [446]. & 4 \\
\hline & $\begin{array}{l}\text { Attention given to } \\
\text { external stimuli }\end{array}$ & $\begin{array}{l}\text { Rostral prefrontal cortex [447]. Plays a role in emotion regulation [448] and } \\
\text { memory [449]. }\end{array}$ & 46 \\
\hline & \multirow{3}{*}{ Observation } & Dorsolateral prefrontal cortex [450], when stimuli deviate from expectations. & 89 \\
\hline & & Inferior temporal area at around $170 \mathrm{~ms}[451]$ in visual art. & 16 \\
\hline & & Insula [452]. & 67 \\
\hline \multirow{23}{*}{ Judgement } & & $\begin{array}{c}\text { General impression (at around } 300 \mathrm{~ms} \text { ): greater negativity in the event-related } \\
\text { potentials of stimuli judged as not being beautiful ([370]. Generated by, among } \\
\text { others, the right lateral orbitofrontal cortex [398] and the medial rostral } \\
\text { prefrontal cortex }[453,454] .\end{array}$ & 286,46 \\
\hline & & $\begin{array}{l}\text { Deep evaluation (at around } 600 \mathrm{~ms} \text { ): hemispheric lateralisation to the right-hand } \\
\text { side of the brain, especially positive when looking at something beautiful [370]. }\end{array}$ & \\
\hline & & Prefrontal area [455]. & 22 \\
\hline & & Left prefrontal dorsolateral cortex, between $400 \mathrm{~ms}$ and $1000 \mathrm{~ms}$ [455]. & 90 \\
\hline & & $\begin{array}{l}\text { Orbitofrontal cortex [456] and its lateral subregion [457,458] for ugly stimuli } \\
\text { [459]. Related to reward evaluation [460] and the taking of morality-related } \\
\text { decisions [461]. }\end{array}$ & 685,286 \\
\hline & & $\begin{array}{c}\text { Connection between the orbitofrontal cortex, anterior insula, rostral cingulate, } \\
\text { and ventral basal ganglia [441]; suggestive of exteroceptive and interoceptive } \\
\text { information comparisons. }\end{array}$ & $\begin{array}{l}685,97 \\
363,35\end{array}$ \\
\hline & & $\begin{array}{l}\text { Medial orbitofrontal cortex [462]. } \\
\text { Activated together with the perceptual area specialised in the specific stimulus } \\
\text { mode [454]. }\end{array}$ & 685 \\
\hline & & Anterior medial prefrontal cortex [463]. & 55 \\
\hline & & $\begin{array}{l}\text { Motor cortex [464]. } \\
\text { While observing sculptures [452]. }\end{array}$ & 214 \\
\hline & & $\begin{array}{l}\text { Left parietal cortex [464] and its subdivision, known as the precuneus [465]. } \\
\text { Concordant with the highest amplitude found in the P3 electrode [466]. }\end{array}$ & 83,171 \\
\hline & & $\begin{array}{l}\text { Left cingulate sulcus, bilateral occipital poles, and fusiform gyri, with greater } \\
\text { activation when looking at preferred pictures [467]. }\end{array}$ & $4,26,62$ \\
\hline & & Occipito-temporal cortex [468]. & 178 \\
\hline & & Right primary visual cortex [469]. & 311 \\
\hline & & Anterior cingulate cortex [464]. & 8 \\
\hline & & Right anterior insula [441]. & 454 \\
\hline & & Right para-hippocampal cortex [470]. & 132 \\
\hline & & Caudate nucleus [454], specifically the right-hand side [453]. & 39 \\
\hline & & Putamen [454]. & 38 \\
\hline & & Putamen and claustrum [471]. & 38,181 \\
\hline & & Globus pallidus [471]. & 113 \\
\hline & & Amygdala $[256,471]$. & 36 \\
\hline & & $\begin{array}{l}\text { Connection between the frontal cortex, the precuneus, and the posterior } \\
\text { cingulate cortex [472]. }\end{array}$ & $18,171,5$ \\
\hline & & $\begin{array}{c}\text { Default mode network, showing increased activation while viewing highly } \\
\text { pleasing images [463]. }\end{array}$ & \\
\hline
\end{tabular}


Table 7. Cont.

\begin{tabular}{|c|c|c|}
\hline Aspect & Related Neurophysiological Activity & WOROI \\
\hline \multirow{7}{*}{ Emotion } & $\begin{array}{l}\text { Orbito-frontal cortex, and its medial subdivision, in different sensorial modes. } \\
\text { Taste: [473]; Smell: [474]; somatosensory: [374]; vision: [464]. }\end{array}$ & 685,285 \\
\hline & Medial temporal lobe [475]. & 218 \\
\hline & Fusiform gyri when looking at smiling faces [476]. & 62 \\
\hline & Striatum [470]. & 37 \\
\hline & Nucleus accumbens [477]. & 245 \\
\hline & Hippocampus [478]. & 40 \\
\hline & Amygdala [479]. & 36 \\
\hline
\end{tabular}

Neural activities have been identified in relation to aspects studied in psychology. Tables 6 and 7 display some of these. The fact that the structures involved are both subcortical and cortical, which are commonly associated with emotion and reason, is the basis of romantic hypotheses about the complexity of art, and the difficulty of producing beauty, in comparison to perceiving it. Given the close coordination between these structures [480], it would make sense to accept that the interaction between the structures is both bottom-up and top-down [481].

Different models establish links between studies. On the one hand, the psychological model of Leder [482] emphasised the interdependence of emotion and aesthetic judgment (they occur simultaneously: the first is the source of aesthetic preference, the second is the output of affective-emotional states) and established five phases of aesthetic experience (perception, explicit classification, implicit classification, cognitive mastering, and evaluation). On the other hand, the Chatterjee neuroscientific model [483] proposes that, in addition to affective-emotional output, there is a decision-making process. The model establishes five phases (processing of simple components, attention to prominent properties, attention modulation, feed-back/feed-forward processes uniting the attentional and attributional circuits, and intervention of the emotional systems). The fundamentals of the Chatterjee's model have recently been contextualised in architecture [484]. Both frameworks represent the aesthetic experience, and have been useful for interpreting later results [485]. However, further research is needed.

\subsubsection{Neuroscience in Architecture}

Neuroscience is being incorporated into the study of the cognitive-emotional dimension of architecture [486]. Seen in retrospect, certain gestalt psychology-influenced developments link the use of neuroscience in architecture [487]. Von Hayek's work [488] and Arnheim's research [489] into the psychology of art and perception of images are examples. Beyond gestalt, and, strictly outside art, Reference [490] made a contribution to the application of neuroscience to behaviour by developing a theory of how complex psychological phenomena can be produced by brain activity. Paired with his ideas, Neutra made one of the first more explicit contemporary formulations of the incorporation of neuroscientific knowledge into architecture [491]. He explained that architecture should satisfy the neurological needs of its users by incorporating the research available into the development of architectural designs. In addition, inspirational is the holistic understanding of human life that Moholy-Nagy expected from architects [492]. The point at which this knowledge began to be accessible to architects, according to some authors [493], was with the publication of "The Embodied Mind" [494]. In this work, the authors coined the term "neurophenomenology," and tried to reconcile the scientific approach with experience [495]. In this sense, Einfühlung has also acquired a neuroscientific substrate in recent years. Freedberg \& Gallese [443] proposed that mirror neurons are responsible for what certain phenomenology authors called "resonance". In this way, neuroscience applications, compared to base approaches, offer substantial benefits [496]. 
Two lines stand out in the exploration of architecture's bases: the design process, and the experience of architecture [497]. The first line has been widely developed in art in general, and has made progress in the architectural field such as in proposals on how to incorporate the knowledge derived from neuroscience's application to architecture into the design process [498-500], and in studies into brain development generated by acquired expertise $[405,501]$. These studies share common ground with neuro-aesthetic research. Frequently examined aspects of the second line are orientation, light, and acoustics. Orientation is part of the daily activity of most people [502]. Studies of diverse natures have tried to explain the principles involved in wayfinding [503-505] with VR being an effective tool [506]. These studies have direct relevance when it comes to improving navigation strategies. There is a long tradition of using light for aesthetic purposes. Since the discovery of the eye's photoreceptive ganglion cells, and their influence on circadian rhythms [507,508], light-centred studies have been complemented by health-focused research [509]. The application of the recommendations based on the results of light-based research could improve the experience of users, especially those with time/light challenges (e.g., night shift workers) [510]. Regarding acoustics, there is a relationship between noise and consequences for humans at different levels [511]. For example, studies have been undertaken into stress recovery during exposure to sounds of a different quality [512]. Leaving aside artistic arguments, the treatment of space acoustics is of considerable importance. In addition to these aspects (orientation, etc.), studies that identify the mechanisms of exposure to restorative environments should be highlighted [513], as should studies into the quantification, based on neurophysiological measures, of the effects of restorative environments in interior [514] and exterior spaces [515,516], the capture of the emotional impact of museum experiences [517-520], the modification of recommended house design variables [521], and works with mixed design aspects [522]. The results of some studies appear in Table 8. Beyond the relative prominence of wayfinding studies, in this table, it can be seen that some variables attract more attention (as do environmental psychology and EBD). The variable contours and ornament, which is a basic architectural design aspect, stands out. These advances show the usefulness of the neuro-architectural approach to the cognitive-emotional dimension of architecture [523-525]. However, although neuroscientific research is extensive and rigorous, its application to architecture is an emerging discipline [526,527]. Thus, there are, as yet, few practical works exclusively focused on improving architectural design. The efforts are dispersed, and a common framework has yet to be established.

Table 8. Neurophysiological foundations of the cognitive-emotional dimension of architecture, and the neuro-behavioural effects generated by architectural design variables studied in the application of neuroscience to architecture.

\begin{tabular}{|c|c|c|}
\hline Aspect/Variable & Neurobehavioural Effect/Related Neurophysiological Activity & WOROI \\
\hline \multirow{8}{*}{ Wayfinding } & $\begin{array}{l}\text { Posterior parietal, premotor, and frontal areas, greater activation when the subject } \\
\text { uses an egocentric frame of reference [528]. }\end{array}$ & $21,217,18$ \\
\hline & $\begin{array}{l}\text { Occipito and temporal area, greater activation when the subject uses an allocentric } \\
\text { frame of reference [528]. }\end{array}$ & 26,15 \\
\hline & $\begin{array}{l}\text { Parietal zone with desynchronised alpha band, in environments where orientation } \\
\text { is difficult [529]. }\end{array}$ & 290 \\
\hline & Occipital area, processes visual features important for landmark recognition [530]. & 26 \\
\hline & Medial temporal area, related to allocentric representations [531]. & 136 \\
\hline & Right lingual sulcus, participates in perception of buildings [532]. & 167 \\
\hline & $\begin{array}{l}\text { Posterior cingulate cortex, and occipital lobe, involved in navigation and } \\
\text { perception from different perspectives [533]. }\end{array}$ & 5,26 \\
\hline & $\begin{array}{c}\text { Anterior midcingulate cortex, greater activation in closed spaces, possibly } \\
\text { generating avoidance decisions [534]. }\end{array}$ & 8 \\
\hline
\end{tabular}


Table 8. Cont.

\begin{tabular}{|c|c|c|}
\hline Aspect/Variable & Neurobehavioural Effect/Related Neurophysiological Activity & WOROI \\
\hline & $\begin{array}{l}\begin{array}{l}\text { Entorhinal cortex, relating memory, and navigation data to create a cognitive map } \\
\text { of events [535]. }\end{array} \\
\end{array}$ & 66 \\
\hline & $\begin{array}{c}\text { Retro-splenial complex retrieves landmark-related spatial and conceptual } \\
\text { information [530]. }\end{array}$ & 310 \\
\hline & $\begin{array}{l}\text { Hippocampus, right posterior parietal, and posterodorsal medial parietal cortex, } \\
\text { related to the retrieval of spatial context [531]. }\end{array}$ & $40,290,21$ \\
\hline & Right hippocampus participates in remembering locations [536]. & 108 \\
\hline & Left hippocampus participates in remembering autobiographical events [537]. & 107 \\
\hline & $\begin{array}{l}\text { Hippocampus, with higher activation in the theta band, hypothetically related to } \\
\text { sensorimotor integration during navigation [538]. }\end{array}$ & 40 \\
\hline & Para-hippocampus codes landmark identity [530]. & 65 \\
\hline & Para-hippocampus participates in the spatial processing of scenes $[539,540]$. & 65 \\
\hline & Para-hippocampus responds, in general, to rectilinear features [541]. & 65 \\
\hline & $\begin{array}{l}\text { Alpha band, with increased activation in occipital electrodes, is associated with } \\
\text { familiar streetscape images [542]. }\end{array}$ & 26 \\
\hline & $\begin{array}{l}\text { Beta band, with increased activation in frontal electrodes, positively correlated } \\
\text { with RMS (root-mean-square) statistics and fractal dimensions [542]. }\end{array}$ & 18 \\
\hline & $\begin{array}{l}\text { Alpha and beta bands indicate that the first three minutes of walking has the } \\
\text { greatest cognitive effects on users [543]. }\end{array}$ & \\
\hline & $\begin{array}{l}\text { Theta band, with increased activation, is associated with increased navigation } \\
\text { performance in women and decreased navigation performance in men [544]. }\end{array}$ & \\
\hline & Theta/alpha ratio related to higher cognition and memory [158]. & \\
\hline \multirow{5}{*}{ Stress } & $\begin{array}{c}\text { Middle frontal gyrus, middle and inferior temporal gyrus, insula, inferior parietal } \\
\text { lobe, and cuneus with higher activation in highly restorative potential } \\
\text { environments [513]. }\end{array}$ & $148,126,67,183,3$ \\
\hline & $\begin{array}{l}\text { Superior frontal gyrus, precuneus, para-hippocampal gyrus, and posterior } \\
\text { cingulate with higher activation in low restorative potential environments [513]. }\end{array}$ & $70,171,65,5$ \\
\hline & $\begin{array}{l}\text { Alpha band with higher activation in the frontal lobe in non-stressful } \\
\text { environments [514]. }\end{array}$ & 18 \\
\hline & $\begin{array}{l}\text { High-beta band with higher activation in the temporal lobe in stressful } \\
\text { environments [514]. }\end{array}$ & 15 \\
\hline & $\begin{array}{l}\text { A combination of multisensory design variables produces a synergistic effect, } \\
\text { which reduces stress. Measured through EDA, HRV, and EEG [15]. }\end{array}$ & \\
\hline \multirow{6}{*}{ Illumination } & White light modulates mood and sleep rhythms [545]. & \\
\hline & Spaces illuminated above $7500 \mathrm{~K}$ increase blood pressure [546]. & \\
\hline & $\begin{array}{l}\text { Arousal differences demonstrated (measured using EEG) in spaces illuminated at } \\
\qquad 5000 \mathrm{~K} \text { and } 3000 \mathrm{~K} \text { [547]. }\end{array}$ & \\
\hline & Blue light accelerates post-stress relaxation [548]. & \\
\hline & $\begin{array}{l}\text { Direct/indirect lighting makes subjects feel cooler and more pleasant, compared to } \\
\text { direct lighting. It also generates more activity in electrodes F4, F8, T4, and TP7. } \\
\text { Under these circumstances, the theta band of the F8 electrode correlated with a } \\
\text { "cool" self-assessment [549]. }\end{array}$ & $91,296,130,123$ \\
\hline & $\begin{array}{l}\text { Difference between cold and neutral colour temperature, at the level of alertness, } \\
\text { fatigue, cognitive functioning, HRV and EDA [550]. }\end{array}$ & \\
\hline Colour & Red coloured spaces increase arousal measured through EEG metrics [551]. & \\
\hline
\end{tabular}


Table 8. Cont.

\begin{tabular}{|c|c|c|}
\hline Aspect/Variable & Neurobehavioural Effect/Related Neurophysiological Activity & WOROI \\
\hline \multirow{9}{*}{$\begin{array}{l}\text { Contours and } \\
\text { ornaments }\end{array}$} & $\begin{array}{l}\text { Anterior cingulate cortex, greater activation when looking at curvilinear } \\
\text { spaces [552]. }\end{array}$ & 8 \\
\hline & $\begin{array}{l}\text { Anterior cingulate cortex with theta band, related to certain spatial } \\
\text { characteristics [533] }\end{array}$ & 8 \\
\hline & $\begin{array}{l}\text { Frontal lobes with event-related potentials of higher positive amplitude, between } \\
300 \text { and } 600 \mathrm{~ms} \text {, when viewing architectural ornaments [553].Susceptible to } \\
\text { cultural modulation [554]. }\end{array}$ & 18 \\
\hline & Curved geometric spaces are preferred over angled geometric spaces [552]. & \\
\hline & $\begin{array}{l}\text { Curved geometric spaces are preferred by non-design expert subjects, and } \\
\text { sharp-angled spaces by expert subjects [555]. }\end{array}$ & \\
\hline & $\begin{array}{l}\text { Angled geometry is not avoided, but curved geometric spaces prompt approach } \\
\text { (rather than avoidance) behaviours [556]. }\end{array}$ & \\
\hline & $\begin{array}{l}\text { Amygdala with greater activation when viewing sharp than curved contours, and } \\
\text { images of landscapes and healthcare objects. However, when viewing images of } \\
\text { hospital interiors and exteriors, there is greater activation with curved contours. it } \\
\text { is hypothesised that, in stress-associated environments, curved contours may not } \\
\text { be desirable [557]. }\end{array}$ & 36 \\
\hline & $\begin{array}{l}\text { Open-office arrangements generate more physical activity, and less stress, } \\
\text { measured through HRV (SDNN) [558]. }\end{array}$ & \\
\hline & $\begin{array}{l}\text { Thigmotaxis plays a role in spatial learning, depending on the phase [559].Human } \\
\text { predisposition for walls: people are thigmotactic [560]. }\end{array}$ & \\
\hline \multirow[b]{2}{*}{ Windows } & $\begin{array}{l}\text { The existence of openings can reduce stress, measured by electrocardiogram (HR, } \\
\text { and HRV-HF, and T-wave amplitude), and cortisol. However, this depends on the } \\
\text { stressor type [561]. }\end{array}$ & \\
\hline & $\begin{array}{l}\text { The geometry of façades, and the lighting that passes through them into interiors, } \\
\text { affects physiological (at an HRV level) and psychological responses in different } \\
\text { ways. Among others, there is deceleration of the heart rate with irregular designs, } \\
\text { in comparison to blinds, because they attract greater attention }[176,562] \text {. }\end{array}$ & \\
\hline \multirow{5}{*}{ Aesthetic judgement } & $\begin{array}{l}\text { Left frontal areas with more theta band activity when viewing pleasant interior } \\
\text { spaces [563]. }\end{array}$ & 81 \\
\hline & $\begin{array}{l}\text { Fusiform face area, involved in fine-grained neural encoding of architectural } \\
\text { scenes [564]. }\end{array}$ & 343 \\
\hline & $\begin{array}{c}\text { Theta band increased across the frontal area, in familiar and comfortable } \\
\text { environments [565]. }\end{array}$ & 18 \\
\hline & $\begin{array}{l}\text { Alpha band increased in left-central parietal and frontal areas in pleasant } \\
\text { environments [565]. }\end{array}$ & 83,18 \\
\hline & $\begin{array}{c}\text { Mu band desynchronised in left motor areas, in pleasant and comfortable } \\
\text { environments [565]. }\end{array}$ & 350 \\
\hline \multirow{4}{*}{ Nature } & Views of nature have positive effects on emotional and physiological states [566]. & \\
\hline & Natural vistas (in videos) produce significantly higher HR than urban vistas [567]. & \\
\hline & $\begin{array}{l}\text { The absence of vegetation generates a more oppressive environment, which affects } \\
\text { the judgment of distance and generates greater arousal measured through } \\
\text { EDA [568]. }\end{array}$ & \\
\hline & $\begin{array}{c}\text { Similar brain patterns between positive images and open sky multisensory } \\
\text { simulations measured through fMRI. The latter also generate activity related to } \\
\text { spatial cognition and space expansion [569]. }\end{array}$ & \\
\hline
\end{tabular}




\section{Discussion}

Based on the scoping review of neuroarchitecture and its precursor approaches, four aspects of the application of neuroscience to architecture were identified: (1) limitations of the approaches, (2) the problems in addressing the cognitive-emotional dimension of architecture, (3) ways to solve the problems, and (4) the limitations of this work.

\subsection{Limitations of the Approaches to the Study of Cognitive-Emotional Dimension of Architecture}

The study of the cognitive-emotional dimension of architecture is complex. New approaches are helping to overcome the limitations of the base approaches and to identify data that can support the validity of design proposals. However, neither approach is without its limitations.

The base approaches to the cognitive-emotional dimension of architecture are generally limited in relation to the environmental stimuli and the evaluation systems used. The new approaches, to an extent, try to overcome these limitations by incorporating VR and neuroscience. Their application to aesthetics and art provides a basis for their application to architecture. However, the fact that art and architecture are related fields does not make them equivalent. Thus, the extrapolation of other knowledge bases to architecture must be undertaken with caution. These aspects are discussed below at ontological, epistemological, and methodological levels.

At an ontological level, the limitations are derived from the perceptual breadth of the experiences. Two deficiencies stand out: (1) the modality of the stimuli used, and (2) the aspects studied. The first limitation involves unimodality. Previous studies have generally focused on the visual domain [570]. Although most of the information we process is in the visual domain [571,572], limiting the exposure to only unimodal stimuli in architecture reduces the richness of the experience $[573,574]$. The second limitation fundamentally involves beauty and pleasure. On the one hand, although beauty plays a central role in people's concept of aesthetics, art, and, therefore, architecture [575]. Non-beautiful works can be art [576]. On the other hand, although pleasure may be derived from the aesthetic or artistic experience [577], pleasurable feelings may be generated for reasons outside the work of art or architecture. Thus, beauty and pleasure are not enough [578].

At the epistemological level, the limitations derive from the difficulty of explaining these experiences in exclusively physiological terms. Two stand out: (1) the neurologyexperience relationship, and (2) the various influential aspects. The first limitation generates the risk of drawing invalid inferences since a brain area can be related to several processes [579]. Emotions are especially complex in this regard [580]. The second limitation relates to the number of aspects that influence artistic and aesthetic experiences [221]. These experiences may seem simple because they are simple to recognize, but not at a neuro-psychological level.

At a methodological level, the limitations derive from the wide variety of stimuli and the many ways in which works can be displayed. Two stand out: (1) procedural conflicts and (2) technical restrictions. The first limitation involves several questions. On the one hand, ceteris paribus logic sacrifices the complexity of the stimuli. In addition, the rigidity of neuroimaging protocols and the laboratory context can alter results. On the other hand, the multiple cognitive-emotional processes involved do not occur simultaneously [581], which may misalign the causal assignment of the recordings. The second limitation relates to the restrictions associated with neurophysiological recording technologies such as the immobility of fMRI. Although these limitations can now be considerably addressed using other devices, such as wearable EEG caps [582] and recordings that can be made outside the laboratory [583-585], they must be taken into account. The limitations all contribute to the lack of a commonly accepted methodology. In a certain way, this lack also obstructs the understanding between different research groups and the comparability of results. While sometimes studies might provide divergent results, it may be because they are reflecting different components of the experience [586]. This leads to the point that the results are also difficult to extrapolate into design guidelines for practical application in architecture. 


\subsection{Problems in Addressing the Cognitive-Emotional Dimension of Architecture}

In addition to the limitations discussed above (applicable to the entire domain of art and aesthetics), there are more specific architecture-based limitations. Mainly two: (1) it is not possible to liken architecture to the artistic-aesthetic, and (2) the experience is not one-off. The first limitation arises from the depth of the architectural function. Architecture tries to meet broad human needs [587]. Although architecture is one of the "Fine Arts" [588], the artistic-aesthetic experience is only one of the components of the cognitive-emotional dimension of architecture. The second limitation is that architecture is an experiential continuum [589]. The transition from one space to another can condition the experience [590], with the "architectural narrative" being significant [560]. In addition, peripheral vision is of special importance [591]. In fact, architecture could be experienced in two ways: intellectually, through focal processing, and in terms of atmosphere, through ambient processing [592]. Furthermore, architecture engages all sensory modalities [278,593], so the visual is insufficient to describe it [96]. This is very important in terms of the study of sensory interaction [594]. Both limitations impede the fragmentation of the cognitive-emotional dimension of architecture, which encourages the tendency toward case studies [595]. In summary, the application of neuroscience to other fields must be cautiously extrapolated to architecture.

The debate on the universality of art should not be forgotten [596,597]. Fundamentally, a perspective based on objective principles might be considered [598], but differences between individuals makes the artistic experience widely subjective [599], which is a circumstance echoed in architecture [600]. To deploy ideas about the universality of art requires retrospective exposition. To begin with, art has developed in parallel with human evolution [601]. It is an exclusively human capacity apart from the structures that some animals produce based on their genetic programming [493]. This is not a reference to the denaturation of art [602], but to its human focus. The key point is that the brain adapts to the environment [603], which is a process known as "neuroplasticity" [604]. Thus, our artistic (and, therefore, architectural) experience is conditioned by biological and environmental factors [605], with the latter having a major impact [606]. Additionally, human brains may change through pathologies (e.g., Alzheimer's disease). Achieving universal art or architecture may not be possible. In fact, there is less agreement when it comes to judging artifacts than natural elements [607]. However, all humans have innately similar brains [608,609], which allows bridges to be built between individuals, societies, and times [610]. Therefore, some common architectural design guidelines may be developed.

\subsection{Beyond the Current State: The Challenges Facing Neuroarchitecture and Its Constituent Disciplines}

Hitherto, there has been no general study of the foundations underlying the cognitiveemotional dimension of architecture. In this sense, neuroarchitecture has potential. The new discipline makes a contribution to an architecture that supports the cognitive-emotional dimension [611], and does not fall into the reductionism of exclusively aspiring to provide relaxation [92]. This might embrace the contemporary emphasis on sustainability and the social dimension [612]. The examples are as varied as the spaces: hospitals that contribute to healing [613], classrooms that support cognitive processes [614], work environments that encourage collaboration [615], museums perceptually adapted to the works that they house [583], restaurants where multisensory integration enhances the gastronomic experience [616], and, among others, urban planning activities [617-620], where one of the challenges lies in the diversity of groups. Designing for specific groups, including those with specific pathologies such as dementia [621-623], involves a frontal confrontation with design for the masses. The success of the different applications of neuroarchitecture will, in part, depend on the ability of its constituent disciplines to overcome its inherent challenges.

User experience is the main issue in VR. Increasing the capacity of VR set-ups to generate the illusion of being in a place (characterised as "place illusion"), and the credibility of the scenarios, to meet the viewer's expectations (characterised as "plausibility illusion"), is 
crucial. Although there is limited understanding what affects the sense of presence, there is consensus on two factors, known as exteroception and interoception. Exteroception factors, which are directly related to the experimental set-up (such as interactivity), increase the sense of presence particularly in virtual environments not designed to induce specific emotions [624]. Interoception factors, defined by the content displayed, increase the presence if the user feels emotionally affected [625]. For example, previous studies have found a strong correlation between arousal and presence [626]. This suggests that, in neuroarchitecture, both factors may be critical. There is a robust interdisciplinary community [627] that is certainly helpful in meeting this challenge. Furthermore, neuroarchitecture and VR share a synergistic relationship in which the former can help us understand and improve virtual spaces with which we interact more.

The analysis of neurophysiological data is challenging [628]. Affective computing, which is an interdisciplinary field based on psychology, computer science, and biomedical engineering [629], will likely play an important role. Several studies have focused on identifying the cognitive-emotional state of subjects by using machine-learning algorithms and by achieving high levels of accuracy $[630,631]$. Many neuroimaging techniques have been used [632]. Affective computing can be transversally applied to many human behaviour topics. Although one of the first applications of affective computing was to neuroeconomics research due to the important relationship that has been found between emotions and decision-making [633], there are revealing and important examples of its application to architecture [634]. In fact, very recent applications in virtual architectural spaces have produced encouraging results [635-637]. For neuroarchitecture, the definition of neurophysiological indices in relation to the cognitive-emotional dimension of architecture would contribute to the development of an actual architectural design tool. These would allow the effect of the architecture on users to be measured in an easy-to-interpret way (e.g., stress through neurophysiological measures expressed in well-defined ranges). The fact that these indices have not yet been fully developed and made available for academic and professional use is one of the reasons that may be holding back the growth of neuroarchitecture. Developed in real time, these could even contribute to adapting spaces to emotional states [638] (for example, automatically modify the lighting of the environment in order to respond to a stressful situation of its user). In this matter, the combination with virtual reality could potentially present yet another facet of the synergy between neuroimaging and virtual reality techniques. For example, by means of augmented reality displayed on HMDs, the user could be stimulated to reduce their stress without physically modifying variables of the environment (which could affect other users who do not meet the same needs). Thus, neuroarchitecture would not only help to answer questions about the cognitive-emotional dimension of architecture, but also to develop a technological layer that supports our cognitive-emotional processes [639].

However, humans are not just neurological entities. Thus, it is not surprising that the cognitive-emotional dimension of architecture has been approached from such different directions. The polyhedral nature of the cognitive-emotional dimension of architecture means that a solution can hardly be derived from one source. Although neuroscience applied to architecture helps to answer questions about the cognitive-emotional dimension of architecture, it does not hold all the answers. Moreover, architecture has traditionally been based on designerly ways of knowing. The architect intuitively explores and exploits some of its perceptual foundations. This offers an economy of means that, sometimes, is ahead of science [640]. Thus, if the ultimate goal is to improve architecture, attention must be paid to both the bases and execution. To do this, it will be necessary to take into account how architects work. "Scientists and artists need to identify common ground" [641]. Only in this way will it be possible to develop the broad and deep knowledge needed to generate a true design tool. 


\subsection{Limitations of the Work}

The present study has some limitations. Fundamentally, (1) the work may be overexhaustive, and (2) possible significant references were not discovered. Exhaustiveness is due to the multiple disciplines involved. Although some overlap exists, the integration of the approaches examined offers a broad view of the issue. As for undiscovered references, it is possible that some interesting works have not been addressed including "grey literature" [642].

\section{Conclusions}

The application of neuroscience to architecture is gaining prominence. The term "neuroarchitecture" seems to work in a promotional sense, likely, in part, due to the tendency to consider neuroscientific content credible [643]. However, it does not seem appropriate at other levels such as computerised searches (mixed with neural architectural issues or artificial intelligence), conceptual (does not do justice to neuroscience or architecture), and technical (does not make clear if it includes works not strictly based on neurophysiological recordings). The ease in translating the term into different languages, and the amount of documentation generated, makes it difficult to adopt more appropriate terms, such as "emotional architecture" or "mental architecture".

In another vein, neuroarchitecture is often decontextualized without considering its main precursor approaches. This creates biases about its current possibilities and future developments and, as with social sciences [644], neuroscientific applications generate some controversy. From some conservative points of view, accepting external guidelines infringes on issues deeply established in the project process. Most of the changes generate neophobic impulses, and the advent and development of neuroarchitecture may mark a paradigm shift. However, the application of neuroscience to architecture is not intended to reduce design to universal standards. Understanding the fundamentals on the cognitiveemotional dimension of architecture does not make it less relevant nor will it remove the need for architects. It will only complement their tool set, that already includes tools (more or less used in practice), such as geometry, phenomenology, geographical experience, philosophy, and, more recently, psychological and EBD approaches. The knowledge offered by neuroarchitecture will help more broadly meet users' needs. A building might not collapse due to poor cognitive-emotional adaptation, but its users might. Although it will take years to design projects entirely using principles and knowledge derived from neuroscientific explorations of the built environment, today, we can take steps to improve the human cognitive-emotional response in the built architectural environment. This includes modifying existing spaces and improving decision-making for the design of new spaces. The combination of advances in neuroscience and environmental simulation will expand the impact of the new discipline. The next great architects may be those who can embrace, without prejudice, these new possibilities. The challenge looks exciting.

Author Contributions: Conceptualization, J.L.H.-T. Methodology, J.L.H.-T. Formal analysis, J.L.H.-T., C.L., and E.M. Investigation, J.L.H.-T., C.L., and E.M. Writing-original draft preparation, J.L.H.-T. Writing-review \& editing, J.L.H.-T. Visualization, J.L.H.-T. Supervision, C.L. and E.M. Project administration, J.L.H.-T. Funding acquisition, C.L. All authors have read and agreed to the published version of the manuscript.

Funding: This work was supported by the Ministerio de Economía, Industria y Competitividad of Spain (Project BIA2017-86157-R). The first author is supported by funding from Ministerio de Economía, Industria y Competitividad of Spain (PRE2018-084051), and the Academy of Neuroscience for Architecture (John Paul Eberhard Fellow).

Institutional Review Board Statement: Not applicable.

Informed Consent Statement: Not applicable. 


\section{Data Availability Statement: Not applicable.}

Conflicts of Interest: The authors declare no conflict of interest. The funders had no role in the design of the study, in the collection, analyses, or interpretation of data, in the writing of the manuscript, or in the decision to publish the results.

\section{References}

1. Williams Goldhagen, S. Welcome to Your World: How the Built Environment Shapes our Lives; HarperCollins: New York, NY, USA, 2017.

2. Ledoux, J.E. Cognitive-Emotional Interactions in the Brain. Cogn. Emot. 2008, 3, 267-289. [CrossRef]

3. Glass, D.C.; Singer, J.E. Urban Stress: Experiments on Noise and Social stressors; Academic Press: New York, NY, USA, 1972.

4. Ulrich, R.S. Visual landscapes and psychological well-being. Landsc. Res. 1979, 4, 17-23. [CrossRef]

5. Glaser, R.; Kiecolt-Glaser, J.K. Stress-induced immune dysfunction: Implications for health. Nat. Rev. Immunol. 2005, 5, $243-251$. [CrossRef] [PubMed]

6. Ulrich, R.S. View through a window may influence recovery. Science 1984, 224, 224-225. [CrossRef] [PubMed]

7. Cross, N. Designerly ways of knowing. Des. Stud. 1982, 3, 221-227. [CrossRef]

8. Sternberg, E.M.; Wilson, M.A. Neuroscience and Architecture: Seeking Common Ground. Cell 2006, 127, $239-242$. [CrossRef] [PubMed]

9. Lu, S.C.; Liu, A. Subjectivity and objectivity in design decisions. CIRP Ann. 2011, 60, 161-164. [CrossRef]

10. Tversky, A.; Kahneman, D. Judgment under Uncertainty: Heuristics and Biases. Science 1974, 185, 1124-1131. [CrossRef] [PubMed]

11. ANFA Neuroscience and Architecture. Health Care Facilities; ANFA: Woods Hole, MA, USA, 2004.

12. Edelstein, E.A.; Macagno, E. Form follows function: Bridging neuroscience and architecture. In Sustainable Environmental Design in Architecture; Rassia, S., Pardalos, P.M., Eds.; Springer: New York, NY, USA, 2012; pp. 27-41. ISBN 978-1-4419-0744-8.

13. Metzger, C. Neuroarchitecture; Jovis Verlag GmbH: Berlin, Germany, 2018.

14. Northoff, G. Humans, Brains, and Their Environment: Marriage between Neuroscience and Anthropology? Neuron 2010, 65, 748-751. [CrossRef] [PubMed]

15. Higuera-Trujillo, J.L.; Llinares Millán, C.; Montañana i Aviñó, A.; Rojas, J.-C. Multisensory stress reduction: A neuro-architecture study of paediatric waiting rooms. Build. Res. Inf. 2020, 48, 269-285. [CrossRef]

16. Cross, E.S.; Ticini, L.F. Neuroaesthetics and beyond: New horizons in applying the science of the brain to the art of dance. Phenomenol. Cogn. Sci. 2012, 11, 5-16. [CrossRef]

17. Chatterjee, A. Neuroaesthetics: A coming of age story. J. Cogn. Neurosci. 2011, 23, 53-62. [CrossRef]

18. Nanda, U.; Pati, D.; McCurry, K. Neuroesthetics and Healthcare Design. HERD Health Environ. Res. Des. J. 2009, 2, 116-133. [CrossRef]

19. Bower, I.; Tucker, R.; Enticott, P.G. Impact of built environment design on emotion measured via neurophysiological correlates and subjective indicators: A systematic review. J. Environ. Psychol. 2019, 66, 101344. [CrossRef]

20. Karakas, T.; Yildiz, D. Exploring the influence of the built environment on human experience through a neuroscience approach: A systematic review. Front. Archit. Res. 2020, 9, 236-247.

21. Azzazy, S.; Ghaffarianhoseini, A.; GhaffarianHoseini, A.; Naismith, N.; Doborjeh, Z. A critical review on the impact of built environment on users' measured brain activity. Archit. Sci. Rev. 2020, 147, 52-60.

22. Rad, P.N.; Behzadi, F.; Yazdanfar, A.; Ghamari, H.; Zabeh, E.; Lashgari, R. Cognitive and perceptual influences of architectural and urban environments with an emphasis on the experimental procedures and techniques. PsyArXiv 2021. [CrossRef]

23. Mallgrave, H.F. The Architect's Brain: Neuroscience, Creativity, and Architecture; John Wiley \& Sons: London, UK, 2010.

24. Pham, M.T.; Rajić, A.; Greig, J.D.; Sargeant, J.M. A scoping review of scoping reviews: Advancing the approach and enhancing the consistency. Res. Synth. Methods 2014, 5, 371-385. [CrossRef]

25. Arksey, H.; O'Malley, L. Scoping studies: Towards a methodological framework. Int. J. Soc. Res. Methodol. 2005, 8, 19-32. [CrossRef]

26. Helewa, A.; Walker, J. Critical Evaluation of Research in Physical Rehabilitation; W.B. Saunders Co.: Philadelphia, PA, USA, 2000.

27. Lang, G.; Heiss, G.D. A practical guide to Research Methods; University Press of America: Lanham, MD, USA, 1998.

28. Hanc, M.; McAndrew, C.; Ucci, M. Conceptual approaches to wellbeing in buildings: A scoping review. Build. Res. Inf. 2019, 47, 767-783. [CrossRef]

29. Slavin, R.E. Best evidence synthesis: An intelligent alternative to meta-analysis. J. Clin. Epidemiol. 1995, 48, 9-18. [CrossRef]

30. Day, R. How to Write and Publish a Scientific Paper; The Oryx Press: Phoenix, AZ, USA, 1998.

31. Hutchinson, B.G. Critical Appraisal of Review Articles. Am. J. Prev. Med. 2007, 32, 361-369.

32. Hutchison, B.G. Critical appraisal of review articles. Can. Fam. Physician 1993, 39, 1102.

33. Denyer, D.; Tranfield, D. Producing a systematic review. In The Sage Handbook of Organizational Research Methods; Buchanan, D., Bryman, A., Eds.; Sage Publications: London, UK, 2009; pp. 671-689.

34. Moher, D.; Liberati, A.; Tetzlaff, J.; Altman, D.G. Preferred reporting items for systematic reviews and meta-analyses: The PRISMA statement. Ann. Intern. Med. 2009, 151, 264-269. [CrossRef]

35. Saunders, M.; Lewis, P.; Thornhill, A. Research Methods for Business Students, 6th ed.; Pearson Education Ltd.: Essex, UK, 2012. 
36. Dixon-Woods, M.; Agarwal, S.; Jones, D.; Young, B.; Sutton, A. Synthesising qualitative and quantitative evidence: A review of possible methods. J. Health Serv. Res. Policy 2005, 10, 45-53. [CrossRef] [PubMed]

37. Bryman, A. Social Research Methods; Oxford University Press: Oxford, UK, 2001.

38. Hsieh, H.F.; Shannon, S.E. Three approaches to qualitative content analysis. Qual. Health Res. 2005, 15, 1277-1288. [CrossRef] [PubMed]

39. Graneheim, U.H.; Lundman, B. Qualitative content analysis in nursing research: Concepts, procedures and measures to achieve trustworthiness. Nurse Educ. Today 2004, 24, 105-112. [CrossRef]

40. Thomas, J.; Harden, A. Methods for the thematic synthesis of qualitative research in systematic reviews. BMC Med. Res. Methodol. 2008, 8, 45. [CrossRef] [PubMed]

41. Golafshani, N. Understanding reliability and validity in qualitative research. Qual. Rep. 2003, 8, 597-607.

42. Hill, C.E.; Thompson, B.J.; Williams, E.N. A guide to conducting consensual qualitative research. Couns. Psychol. 1997, 25, 517-572. [CrossRef]

43. Tuan, Y. Topofilia: Un Estudio de las Percepciones, Actitudes y Valores Sobre el Entorno; Melusina: Barcelona, Spain, 2007; ISBN 9788496614178.

44. Robinson, S. Nesting: Body, Dwelling, Mind; William Stout Publishers: San Francisco, CA, USA, 2011.

45. Robinson, S. Introduction: Survival through Design. In Mind in Architecture: Neuroscience, Embodiment, and the Future of Design; Robinson, S., Pallasmaa, J., Eds.; MIT Press: Cambridge, MA, USA, 2015; pp. 1-8.

46. Hietanen, J.K.; Korpela, K.M. Do both negative and positive environmental scenes elicit rapid affective processing? Environ. Behav. 2004, 36, 558-577. [CrossRef]

47. ANFA. Mapping Memory of Space \& Place. Report on the 2005 Workshop on Neuroscience E Health Care Architecture; ANFA: Woods Hole, MA, USA, 2005.

48. Gage, F.H. Theme Presentation; The Salk Institute: San Diego, CA, USA, 2003.

49. Malinin, L.H. Will 'good' Architecture make us more creative? Examining the role of place in creative cognition. In Proceedings of the 2014 ANFA Conference; Albright, T., Cooke, G., Marks, F., Whitelaw, A., Macagno, E., Eds.; The Academy of Neuroscience for Architecture: La Jolla, CA, USA, 2014; pp. 18-19.

50. Bruer, J.T. Education and the Brain: A Bridge Too Far. Educ. Res. 1997, 26, 4-16. [CrossRef]

51. Perry, B.D. Childhood experience and the expression of genetic potential: What childhood neglect tells us about nature and nurture. Brain mind 2002, 3, 79-100. [CrossRef]

52. Al-Ayash, A.; Kane, R.T.; Smith, D.; Green-Armytage, P. The influence of color on student emotion, heart rate, and performance in learning environments. Color Res. Appl. 2015, 42, 196-205. [CrossRef]

53. Averill, J.R. Personal control over aversive stimuli and its relationship to stress. Psychol. Bull. 1973, 80, 286-303. [CrossRef]

54. Kiecolt-Glaser, J.K.; Page, G.G.; Marucha, P.T.; MacCallum, R.C.; Glaser, R. Psychological influences on surgical recovery: Perspectives from psychoneuroimmunology. Am. Psychol. 1998, 53, 1209-1218. [CrossRef]

55. Stichler, J.F. Creating healing environments in critical care units. Crit. Care Nurs. Q. 2001, 24, 1-20. [CrossRef] [PubMed]

56. Pinter-Wollman, N.; Jelić, A.; Wells, N.M. The impact of the built environment on health behaviours and disease transmission in social systems. Philos. Trans. R. Soc. B Biol. Sci. 2018, 373, 20170245. [CrossRef]

57. Kim, J.; Kaplan, R. Physical and psychological factors in sense of community: New urbanist Kentlands and nearby Orchard Village. Environ. Behav. 2004, 36, 313-340. [CrossRef]

58. Powell, K. Inspiration from architecture: Building a better scientific rapport. Nature 2003, 424, 858-859. [CrossRef] [PubMed]

59. Newman, O. Defensible Space; MacMillan: New York, NY, USA, 1972.

60. Hollier, D. Against Architecture: The Writings of Georges Bataille; MIT Press: Athens, GA, USA, 1992.

61. Dijkstraa, K.; Pieterseb, M.E. Individual Differences in Reactions towards Colour in Simulated Healthcare Environments: The Role of Stimulus Screening Ability. Environ. Psychol. 2008, 28, 268-277. [CrossRef]

62. Aiello, J.; Epstein, Y.; Karlin, R. Effects of crowding on electrodermal activity. Sociol. Symp. 1975, 14, 43-58.

63. Vannuci, M.; Gori, S.; Kojima, H. The spatial frequencies influence the aesthetic judgment of buildings transculturally. Cogn. Neurosci. 2014, 5, 143-149. [CrossRef] [PubMed]

64. Nanda, U.; Pati, D.; Ghamari, H.; Bajema, R. Lessons from neuroscience: Form follows function, emotions follow form. Intell. Build. Int. 2013, 5, 61-78. [CrossRef]

65. Schildt, G. Alvar Aalto in His Own Words; Otava: Helsinki, Finland, 1997.

66. Pallasmaa, J. Esencias; Gustavo Gili: Barcelona, Spain, 2018.

67. Eberhard, J.P. Applying Neuroscience to Architecture. Neuron 2009, 62, 753-756. [CrossRef] [PubMed]

68. Veal, A. RIBA symposium encourages new links between design and research. Archit. Res. Q. 2005, 9, 17-19. [CrossRef]

69. Changeux, J.P. Neuronal Man; Princeton University Press: Princeton, NJ, USA, 1985.

70. Pearson, D. In Search of Natural Architecture; Abbeville Press: New York, NY, USA, 2005.

71. Powell, J.A. Is architectural design a trivial pursuit? Des. Stud. 1987, 8, 187-206. [CrossRef]

72. Bermudez, J.; Krizaj, D.; Lipschitz, D.; Yurgelun-Todd, D.; Nakamura, Y. fMRI study of architecturally-induced contemplative states. In Proceedings of the 2014 ANFA Conference; Albright, T., Cooke, G., Marks, F., Whitelaw, A., Macagno, E., Eds.; The Academy of Neuroscience for Architecture: La Jolla, CA, USA, 2014; pp. 18-19.

73. Meyakawa, K. Thoughts on Civilization in Architecture, AD. May 1965; 229-230. 
74. van Eyck, A. Verleden, Heden En Toekomst. Forum 1967.

75. Debord, G. La sociedad Del Espectáculo; Pre-textos: Valencia, Spain, 2003.

76. Zeisel, J. Inquiry by Design: Inquiry by design. In Environment/Behavior/Neuroscience in Architecture, Interiors, Landscape, and Planning; W. W. Norton \& Company: New York, NY, USA, 2006.

77. García Cortés, J.M. Espacios Diferenciales. In Experiencias Urbanas Entre El Arte Y La Arquitectura; Armand Llacer: Paterna, Spain, 2007.

78. Ramírez, J.A. Edificios-Cuerpo: Cuerpo Humano Y Arquitectura: Analogías, Metáforas, Derivaciones; Siruela: Madrid, Spain, 2003.

79. Palladio, A. Los Cuatro Libros de la Arquitectura; Limusa-Universidad Autónoma Metropolitana: Ciudad de Mexico, Mexico, 2005.

80. Corbusier, L. Le Modulor/Modulor 2; Ediciones Apóstrofe: Madrid, Spain, 2005.

81. Vitruvio, M. Los Diez Libros de Arquitectura; Alianza Editorial: Madrid, Spain, 2016.

82. Filarete, A.A. Treatise on architecture; Yale University Press: New Haven, CT, USA, 1965.

83. Alberti, L.B. On the Art of Building in Ten Books; MIT Press: Cambridge, MA, USA, 1988.

84. Alberti, L.B. Tratado de Pintura; Universidad Autónoma Metropolitana: Ciudad de México, Mexico, 1998.

85. Durand, J.N.L. Précis of the Lectures on Architecture; The Getty Research Institute: Los Angeles, CA, USA, 2000.

86. Klint, K. Undervisning i møbeltegning ved Kunstakademiet. Arkit. Manedshæfte. 1930, 13, 193-224.

87. Bataille, G. Dictionnaire Critique; Documents: Paris, France, 1929.

88. Zevi, B. Hacia una Arquitectura Orgánica; Poseidon: Buenos Aires, Argentina, 1957.

89. Smithson, P. Conversaciones con Estudiantes: Un Espacio Para Nuestra Generación; Gustavo Gili: Barcelona, Spain, 2004.

90. Niemeyer, O. As curvas do Tempo: Memórias; Revan: Rio de Janeiro, Brazil, 1998.

91. Mollino, C.; Vadacchino, F. Architettura: Arte e Tecnica; Chiantore: Torino, Italy, 1948.

92. Ruggles, D.H. Beauty, Neuroscience, and Architecture: Timeless Patterns and Their Impact on Our Well-Being; University of Oklahoma Press: Denver, CO, USA, 2017.

93. Höge, H. Fechner's experimental aesthetics and the golden section hypothesis today. Empir. Stud. Arts 1995, 13, 131-148. [CrossRef]

94. Franz, G.; von der Heyde, M.; Bülthoff, H.H. An empirical approach to the experience of architectural space in virtual reality-exploring relations between features and affective appraisals of rectangular indoor spaces. Autom. Constr. 2005, 14, 165-172. [CrossRef]

95. Mehta, B.K.; Lee, H.; Shafle, M. Neuroscience of the Golden Ratio. In Proceedings of the ANFA Conference-Poster Session; Academy of Neuroscience for Architecture: La Jolla, CA, USA, 2012.

96. Dzebic, V.; Perdue, J.S.; Ellard, C.G. The influence of visual perception on responses towards real-world environments and application towards design. Intell. Build. Int. 2013, 5, 29-47. [CrossRef]

97. Banaei, M.; Ahmadi, A.; Yazdanfar, A. Application of AI methods in the clustering of architecture interior forms. Front. Archit. Res. 2017, 6, 360-373. [CrossRef]

98. Cavalcante, A.; Mansouri, A.; Kacha, L.; Barros, A.K.; Takeuchi, Y.; Matsumoto, N.; Ohnishi, N. Measuring streetscape complexity based on the statistics of local contrast and spatial frequency. PLoS ONE 2014, 9, e87097. [CrossRef] [PubMed]

99. Coburn, A.; Kardan, O.; Kotabe, H.; Steinberg, J.; Hout, M.C.; Robbins, A.; MacDonald, J.; Hayn-Leichsenring, G.; Berman, M.G. Psychological responses to natural patterns in architecture. J. Environ. Psychol. 2019, in press. [CrossRef]

100. Kacha, L.; Matsumoto, N.; Mansouri, A.; Cavalcante, A. Predicting perceived complexity using local xontrast statistics and fractal information. Courr. Savoir 2013, 16, 89-97.

101. Husserl, E. Ideas: General Introduction to Pure Phenomenology; Routledge Classics: London, UK, 2012.

102. Husserl, E. Ideen su einer Reinen Phänomenologie und Phänomenologischen Philosophie [Ideas Relativas a una Fenomenología pura y una Filosofía Fenomenológica]; Fondo de Cultura Económica: Querétaro, Mexico, 1913.

103. Heidegger, M. El Ser y el Tiempo; Fondo de Cultura Economica: Madrid, Spain, 1998; Volume 2a, ISBN 84-375-0184-9.

104. Dürckheim, K. Untersuchungen zum gelebten Raum. Neue Psychol. Stud. 1932, 6, 383-480.

105. Minkowski, E. Vers une Cosmologie; Aubier: Paris, France, 1967.

106. Buytendijk, F.J.J. Situation, Beiträge zur Phänomenologischen Psychologie und Psychopathologie; Spectrum: Utrecht, Germany, 1954.

107. Lewin, K. Der Richtungsbegriff in der Psychologie: Der spezielle und allgemeine hodologische Raum. Psychol. Forsch. 1934, 19, 249-265. [CrossRef]

108. Sartre, J.P. L'Être et le Néant; Encyclopaedia Universalies: Paris, France, 2016.

109. Bachelard, G. La Poética Del Espacio; Fondo de Cultura Económica: Madrid, Spain, 2005; Volume 183, ISBN 843750368X.

110. Rasmussen, S.E. La Experiencia De La Arquitectura: Sobre La Percepción De Nuestro Entorno; Reverté: Barcelona, Spain, 2004.

111. Bollnow, O.F. Hombre y Espacio; Labor: Barcelona, Spain, 1969.

112. Lacoste, Y. Mondialisation et géopolitique. Hérodote 2003, 108, 3-43. [CrossRef]

113. Buttimer, A.; Seamon, D. The Human Experience of Space and Place; Croom Helm: London, UK, 1980.

114. Gutiérrez Plaza, J.I.; Somoza Medina, J. De itinera balearica. Crónica del VIII Coloquio y Jornadas de campo de Geografía Urbana. Boletin AGE 2006, 42, 329-340.

115. Lynch, K. La Imagen de la Ciudad; Gustavo Gili: Barcelona, Spain, 2008.

116. Vara Muñoz, J.L. Un análisis necesario: Epistemología de la geografía de la percepción. Pap. Geogr. 2010, 51-52, 337-344.

117. Pallasmaa, J. The Geometry of Feeling. A Look at the Phenomenology of Architecture. Skala Nord. J. Archit. Art 1985, 4, $22-25$. 
118. Pallasmaa, J. From metaphorical to ecological functionalism. Archit. Rev. 1993, 193, 74-79.

119. Holl, S.; Pallasmaa, J.; Pérez-Gómez, A.P. Questions of Perception: Phenomenology of Architecture; A+U: Tokyo, Japan, 1994.

120. Pérez-Gómez, A. Mood and Meaning in Architecture. In Mind in Architecture: Neuroscience, Embodiment, and the Future of Design; Robinson, S., Pallasmaa, J., Eds.; MIT Press: Cambridge, MA, USA, 2015; pp. 219-235.

121. Böhme, G. The Aesthetics of Atmospheres; Thibaud, J.-P., Ed.; Routledge: New York, NY, USA, 2017.

122. Schmitz, H.; Müllan, R.O.; Slaby, J. Emotions outside the box-The new phenomenology of feeling and corporeality. Phenomenol. Cogn. Sci. 2011, 10, 241-259. [CrossRef]

123. Griffero, T. Atmosferologia: Estetica Degli Spazi Emozionali; Laterza: Roma-Bari, Italy, 2010.

124. Griffero, T.; Moretti, G. Atmosphere/Atmospheres: Testing A New Paradigm; Mimesis International: Varese, Italy, 2018.

125. Gross, R. Psychology: The Science of Mind and Behaviour; Hodder Education: London, UK, 2015.

126. Bones, M.; Secchiaroli, G. Environmental Psychology: A Psycho-Social Introduction; Sage: London, UK, 1995.

127. Kaminski, G. Umweltpsychologie: Perspektiven, Probleme, Praxis; Klett: Stuttgart, Germany, 1976.

128. Kruse, L.; Graumann, C. Environmental psychology in Germany. In Handbook of Environmental Psychology; Bechtel, R.B., Churchman, A., Eds.; Wiley \& Sons: New York, NY, USA, 1987; pp. 1195-1226.

129. Pol, E. La Psicología Ambiental en Europa; Anthropos Editorial: Barcelona, Spain, 1988.

130. Burke, E. A Philosophical Inquiry into the Origin of Our Ideas of the Sublime and Beautiful; Simon \& Brown: Pall-Mall, UK, 2003.

131. Kant, I. Crítica de la Razón Pura; Tecnos: Madrid, Spain, 2004.

132. Zeising, A. Neue Lehre von den Proportionen des menschlichen Körpers; Vero Verlag: Norderstedt, Germany, 2015.

133. Vischer, F.T. Kritische Gänge: Kritik Meiner Aesthetik; Cotta: Stuttgart, Germany, 1866.

134. Vischer, R. On the Optical Sense of Form: A Contribution to Aesthetics. In Empathy, Form, and Space: Problems in German Aesthetics; Francis, H., Ed.; University of Chicago Press: Chicago, IL, USA, 1994.

135. Fechner, G.T. Vorschule der aesthetik; Breitkopf \& Härtel: Leipzig, Germany, 1876.

136. Wundt, W.M. Principles of Physiological Psychology; General Books LLC: London, UK, 2009.

137. Stumpf, C. On the Psychological Origin of Spatial Imagination; Hirzel: Leipzig, Germany, 1873.

138. Ash, M.G. Gestalt Psychology in German Culture, 1890-1967: Holism and the Quest for Objectivity; Cambridge University Press: Cambridge, UK, 1998.

139. Sternberg, R.J. Cognitive Psychology; Harcourt Brace College Publishers: Orlando, FL, USA, 1996.

140. Koffka, K. Principles of Gestalt Psychology; International, M., Ed.; East Lansing, MI, USA, 2014.

141. Köhler, W. Die physischen Gestalten in Ruhe und Im stationären Zustand. Eine Naturphilosophische Untersuchung; Vieweg+Teubner Verlag: Braunschweing, Germany, 1920.

142. Köhler, W. Gestalt Psychology: An Introduction to New Concepts in Modern Psychology; Liveright Publishing Corporation: New York, NY, USA, 1992.

143. Sheynin, O. Fechner as a statistician. Br. J. Math. Stat. Psychol. 2004, 57, 53-72. [CrossRef]

144. Osgood, C.E.; Suci, G.J.; Tannenbaum, P.H. The Measurement of Meaning; University of Illinois Press: Urbana, IL, USA, 1957.

145. Küller, R. A Semantic Model for Describing Perceived Environment; National Swedish Institute for Building Research: Stockholm, Sweden, 1972; ISBN 91-540-2079-4.

146. Küller, R. Architecture and emotions. In Architecture for People; Milkellides, B., Ed.; Studio Vista: London, UK, 1980; pp. 87-100.

147. Küller, R. Environmental assessment from a neuropsychological perspective. In Environment Cognition and Action: An Integrated Approach; Garling, T., Evans, G.W., Eds.; Oxford University Press: New York, NY, USA, 1991; pp. 111-147.

148. Russell, J.A.; Mehrabian, A. Evidence for a three-factor theory of emotions. J. Res. Pers. 1977, 11, 273-294. [CrossRef]

149. Gifford, R.; Hine, D.W.; Muller-Clemm, W.; Reynolds, D.J.; Shaw, K.T. Decoding Modern Architecture: A Lens Model Approach for Understanding the Aesthetic Differences of Architects and Laypersons. Environ. Behav. 2000, 32, 163-187. [CrossRef]

150. Ergan, S.; Shi, Z.; Yu, X. Towards quantifying human experience in the built environment: A crowdsourcing based experiment to identify influential architectural design features. J. Build. Eng. 2018, 20, 51-59. [CrossRef]

151. Nagamachi, M. Kansei Engineering: A new ergonomic consumer-oriented technology for product development. Int. J. Ind. Ergon. 1995, 15, 3-11. [CrossRef]

152. Higuera-Trujillo, J.L.; Montañana i Aviñó, A.; Llinares Millán, C. User evaluation of neonatology ward design: An application of Focus Group and Semantic Differential. HERD Heal. Environ. Res. Des. J. 2017, 10, 23-48. [CrossRef]

153. Kinoshita, Y.; Cooper, E.W.; Hoshino, Y.; Kamei, K. Kansei and colour harmony models for townscape evaluation. Proc. Inst. Mech. Eng. Part I J. Syst. Control Eng. 2006, 220, 725-734. [CrossRef]

154. Sendai, S. Architectural Kansei of "Wall" in the façade design by Le Corbusier. Kansei Eng. Int. J. 2011, 10, 29-36. [CrossRef]

155. Llinares, C.; Page, A.; Llinares, J. An approach to defining strategies for improving city perception. Case study of Valencia, Spain. Cities 2013, 35, 78-88. [CrossRef]

156. Levin, D.J. Defining Evidence-Based Design. Healthc. Des. Mag. 2008, 8, 8.

157. Edelstein, E.A.; Doctors, S.; Brandt, R.; Denton, B.; Cranz, G.; Mangel, R.; Martin, M.; Chong, G.H. The effects of colour and light on health: Trans-disciplinary research results. World Health Des. 2008, 1, 57-61.

158. Ulrich, R.S. Essay: Evidence-based health-care architecture. Lancet 2006, 368, S38-S39. [CrossRef]

159. van der Voordt, T.J.; Vrielink, D.; van Wegen, H.B. Comparative floorplan-analysis in programming and architectural design. Des. Stud. 1997, 18, 67-88. [CrossRef] 
160. Sherman, S.A.; Varni, J.W.; Ulrich, R.S.; Malcarne, V.L. Post-occupancy evaluation of healing gardens in a pediatric cancer center. Landsc. Urban Plan. 2005, 73, 167-183. [CrossRef]

161. Devlin, A.S.; Arneill, A.B. Health care environments and patient outcomes: A review of the literature. Environ. Behav. 2003, 35, 665-694. [CrossRef]

162. Iyendo, T.O. Exploring the effect of sound and music on health in hospital settings: A narrative review. Int. J. Nurs. Stud. 2016, 63, 82-100. [CrossRef]

163. Salonen, H.; Lahtinen, M.; Lappalainen, S.; Nevala, N.; Knibbs, L.D.; Morawska, L.; Reijula, K. Physical characteristics of the indoor environment that affect health and wellbeing in healthcare facilities: A review. Intell. Build. Int. 2013, 5, 3-25. [CrossRef]

164. Ulrich, R.S. Effects of gardens on health outcomes: Theory and research. In Healing Gardens: Therapeutic Benefits and Design Recommendations; Marcus, C.C., Barnes, M., Eds.; Wiley: New York, NY, USA, 1999; pp. 27-86.

165. Ulrich, R.S.; Zimring, C.; Zhu, X.; DuBose, J.; Seo, H.B.; Choi, Y.S.; Quan, X.; Joseph, A. A review of the research literature on evidence-based healthcare design. HERD Health Environ. Res. Des. J. 2008, 1, 61-125. [CrossRef] [PubMed]

166. Zhang, Y.; Tzortzopoulos, P.; Kagioglou, M. Healing built-environment effects on health outcomes: Environment-occupant-health framework. Build. Res. Inf. 2019, 47,747-766. [CrossRef]

167. Banasiak, M. From Benchtop to Bedside: Exchanging Research Lessons Learned in An Undergraduate Program; The American Institute of Architects: Denver, CO, USA, 2008.

168. Malenbaum, S.; Keefe, F.J.; Williams, A.; Ulrich, R.; Somers, T.J. Pain in its environmental context: Implications for designing environments to enhance pain control. Pain 2008, 134, 241-244. [CrossRef] [PubMed]

169. Ulrich, R.S.; Zimring, C.; Quan, X.; Joseph, A. The environment's impact on stress. In Improving Healthcare with Better Building Design; Marberry, S., Ed.; Health Administration Press: Chicago, IL, USA, 2006; pp. 37-61.

170. Aaron, J.N.; Carlisle, C.C.; Carskadon, M.A.; Meyer, T.J.; Hill, N.S.; Millman, R.P. Environmental noise as a cause of sleep disruption in an intermediate respiratory care unit. Sleep 1996, 19, 707-710. [CrossRef] [PubMed]

171. Carpman, J.R.; Grant, M.A.; Simmons, D.A. Avoiding the hidden costs of ineffective wayfinding. Health Facil. Manag. 1990, 3 , 28-30.

172. Algase, D.L.; Beattie, E.R.; Antonakos, C.; Beel-Bates, C.A.; Yao, L. Wandering and the physical environment. Am. J. Alzheimer's Dis. Other Dement. 2010, 25, 340-346. [CrossRef] [PubMed]

173. Barlas, D.; Sama, A.E.E.; Ward, M.F.F.; Lesser, M.L.L. Comparison of the auditory and visual privacy of emergency department treatment areas with curtains versus those with solid walls. Ann. Emerg. Med. 2001, 28, 135-139. [CrossRef]

174. Chaudhury, H.; Mahmood, A.; Valente, M. Advantages and Disadvantages of Single-Versus Multiple-Occupancy Rooms in Acute Care Environments A Review and Analysis of the Literature. Environ. Behav. 2005, 37, 760-786. [CrossRef]

175. Leather, P.; Beale, D.; Santos, A.; Watts, J.; Lee, L. Outcomes of environmental appraisal of different hospital waiting areas. Environ. Behav. 2003, 35, 842-869. [CrossRef]

176. Dobkins, K.R.; Heyman, G.D. Using neuroscience and behavioural data to tailor visual environments for infants and children. Intell. Build. Int. 2013, 5, 79-93. [CrossRef]

177. Meyers-Levy, J.; Zhu, R. The influence of ceiling height: The effect of priming on the type of processing that people use. J. Consum. Res. 2007, 34, 174-186. [CrossRef]

178. Taher, R. Organizational Creativity through Space Design; International Center for Studies in Creativity, Buffalo State College: Buffalo, NY, USA, 2008.

179. Erkan, İ. Examining wayfinding behaviours in architectural spaces using brain imaging with electroencephalography (EEG). Archit. Sci. Rev. 2018, 61, 410-428. [CrossRef]

180. Hull IV, R.B.; Harvey, A. Explaining the emotion people experience in suburban parks. Environ. Behav. 1989, 21, 323-345. [CrossRef]

181. Joye, Y.; De Block, A. "Nature and I are Two": A Critical Examination of the Biophilia Hypothesis. Environ. Values 2011, 20, 189-215. [CrossRef]

182. Kellert, S.R.; Heerwagen, J.; Mador, M. Biophilic Design: The Theory, Science and Practice of Bringing Buildings to Life; John Wiley \& Sons: Hoboken, NJ, USA, 2008.

183. Kaplan, R.; Kaplan, S. The Experience of Nature: A Psychological Perspective; Cambridge University Press: New York, NY, USA, 1989.

184. Joye, Y. Architectural lessons from environmental psychology: The case of biophilic architecture. Rev. Gen. Psychol. 2007, 11, 305-328. [CrossRef]

185. Dosen, A.S.; Ostwald, M.J. Evidence for prospect-refuge theory: A meta-analysis of the findings of environmental preference research. City, Territ. Archit. 2016, 3, 4. [CrossRef]

186. Hildebrand, G. Origins of Architectural Pleasure; University of California Press: Los Angeles, CA, USA, 1999.

187. Appleton, J. The Experience of Landscape; Wiley: London, UK, 1975.

188. Kruithof, A.A. Tubular luminescence lamps for general illumination. Philips Tech. Rev. 1941, 6, 65-96.

189. Park, M.Y.; Chai, C.G.; Lee, H.K.; Moon, H.; Noh, J.S. The Effects of Natural Daylight on Length of Hospital Stay. Environ. Health Insights 2018, 12. [CrossRef]

190. Houser, K.W.; Tiller, D.K.; Bernecker, C.A.; Mistrick, R.G. The subjective response to linear fluorescent direct/indirect lighting systems. Light. Res. Technol. 2002, 34, 243-260. [CrossRef]

191. Knez, I. Effects of indoor lighting on mood and cognition. J. Environ. Psychol. 1995, 15, 39-51. [CrossRef] 
192. Zhang, X.; Zuo, B.; Erskine, K.; Hu, T. Feeling light or dark? Emotions affect perception of brightness. J. Environ. Psychol. 2016, 47, 107-111. [CrossRef]

193. Zeki, S. The representation of colours in the cerebral cortex. Nature 1980, 284, 412-418. [CrossRef] [PubMed]

194. Maffei, L.; Fiorentini, A. Arte e Cervello; Zanichelli: Bologna, Italy, 1995.

195. Hogg, J.; Goodman, S.; Porter, T.; Mikellides, B.; Preddy, D.E. Dimensions and determinants of judgements of colour samples and a simulated interior space by architects and non-architects. Br. J. Psychol. 1979, 70, 231-242. [CrossRef] [PubMed]

196. Yildirim, K.; Hidayetoglu, M.L.; Capanoglu, A. Effects of interior colors on mood and preference: Comparisons of two living rooms. Percept. Mot. Skills 2011, 112, 509-524. [CrossRef] [PubMed]

197. Chamilothori, K.; Chinazzo, G.; Rodrigues, J.; Dan-Glauser, E.; Wienold, J.; Andersen, M. Subjective and physiological responses to façade and sunlight pattern geometry in virtual reality. Build. Environ. 2019, 150, 144-155. [CrossRef]

198. Pals, R.; Steg, L.; Dontje, J.; Siero, F.W.; van Der Zee, K.I. Physical features, coherence and positive outcomes of personenvironment interactions: A virtual reality study. J. Environ. Psychol. 2014, 40, 108-116. [CrossRef]

199. Bateson, J.E.; Hui, M.K. The Ecological Validity of Photographic Slides and Videotapes in Simulating the Service Setting. J. Consum. Res. 1992, 19, 271-281. [CrossRef]

200. Ijsselsteijn, W.A.; de Ridder, H.; Freeman, J.; Avons, S.E. Presence: Concept, determinants and measurement. In Proceedings of the SPIE Human Vision and Electronic Imaging V.; Rogowitz, B.E., Thrasyvoulos, N.P., Eds.; SPIE: San Jose, CA, USA, 2000 ; pp. 520-529.

201. Schwarz, N.; Strack, F. Reports of subjective well-being: Judgmental processes and their methodological implications. Well-Being Found. Hedonic Psychol. 1999, 7, 61-84.

202. Zaltman, G. How Customers Think: Essential Insights into the Mind of the Market; Harvard Business School Press: Boston, MA, USA, 2003.

203. Rheingold, H. Virtual Reality: Exploring the Brave New Technologies of Artificial Experience and Interactive Worlds—From Cyberspace to Teledildonics; Simon \& Schuster: New York, NY, USA, 1991.

204. Vince, J. Introduction to Virtual Reality; Springer: New York, NY, USA, 2004.

205. Winkielman, P.; Berntson, G.G.; Cacioppo, J.T. The psychophysiological perspective on the social mind. In Blackwell Handbook of Social Psychology: Intraindividual Processessychology; Tesser, A., Schwarz, N., Eds.; Blackwell Publishers: Oxford, UK, 2001; pp. 89-108.

206. Poels, K.; Dewitte, S. How to capture the heart? Reviewing 20 years of emotion measurement in advertising. J. Advert. Res. 2006, 46, 18-37. [CrossRef]

207. Reinerman-Jones, L.; Cosenzo, K.; Nicholson, D. Subjective and Objective Measures of Operator State in Automated Systems. In Advances in Understanding Human Performance. Neuroergonomics, Human Factors Design, and Special Populations; Marek, T., Karwowski, W., Valerie, R., Eds.; CRC Press: Boca Ratón, FL, USA, 2010; pp. 122-131.

208. Reinerman-Jones, L.; Sollins, B.; Gallagher, S.; Janz, B. Neurophenomenology: An integrated approach to exploring awe and wonder. S. Afr. J. Philos. 2013, 32, 295-309. [CrossRef]

209. Kandel, E.R. Principles of Neural Science; McGraw-Hill Education: New York, NY, USA, 2013.

210. Grabenhorst, F.; Rolls, E.T. Value, pleasure and choice in the ventral prefrontal cortex. Trends Cogn. Sci. 2011, 15, 56-67. [CrossRef] [PubMed]

211. Kircher, T.; David, A. The Self in Neuroscience and Psychiatry; Cambridge University Press: Cambridge, UK, 2003.

212. Dewey, J. El arte como Experiencia; Paidós Ibérica: Barcelona, Spain, 2008.

213. Breedlove, S.M.; Watson, N.V. Behavioral Neuroscience; Sinauer Associates: Sunderland, UK, 2019.

214. Solms, M.; Turnbull, O. The Brain and the Inner World: An Introduction to the Neuroscience of Subjective Experience; Karnac Books: London, UK, 2002.

215. Clément, G.; Reschke, M.F. Neuroscience in Space; Springer Science \& Business Media: New York, NY, USA, 2010.

216. de Paiva, A. Neuroscience for architecture: How building design can influence behaviors and performance. J. Civ. Eng. Archit. 2018, 12, 132-138.

217. Nold, C. Emotional Cartography. Technologies of the Self. Available online: www.emotionalcartography.net/ (accessed on 18 March 2021).

218. ANFA. Neuroscience \& The Architecture of Spiritual Spaces; ANFA: Columbus, OH, USA, 2005.

219. Eberhard, J.P. Architecture and the Brain: A new Knowledge Base from Neuroscience; Ostberg: Atlanta, GA, USA, 2007.

220. Edelstein, E.A. Translational Design: The Relevance of Neuroscience to Architecture. In International Conference and Exhibition on Health Facility Planning, Design and Construction (PDC); American Society for Healthcare: San Diego, CA, USA, 2006.

221. Cela-Conde, C.J.; Agnati, L.; Huston, J.P.; Mora, F.; Nadal, M. The neural foundations of aesthetic appreciation. Prog. Neurobiol. 2011, 94, 39-48. [CrossRef] [PubMed]

222. Zaidel, D. Neuropsychology of Art; Psychology Press: New York, NY, USA, 2005.

223. Boeve, B.F.; Geda, Y.E. Polka music and semantic dementia. Neurology 2001, 57, 1485. [CrossRef] [PubMed]

224. Gosselin, N.; Peretz, I.; Johnsen, E.; Adolphs, R. Amygdala damage impairs emotion recognition from music. Neuropsychologia 2007, 45, 236-244. [CrossRef]

225. Blanke, O.; Ortigue, S.; Landis, T. Color neglect in an artist. Lancet 2003, 316, 264. [CrossRef]

226. Cantagallo, A.; Sala, S.D. Preserved insight in an artist with extrapersonal spatial neglect. Cortex 1998, 34, 163-189. [CrossRef]

227. Halligan, P.W.; Marshall, J.C. The art of visual neglect. Lancet 1997, 350, 139-140. [CrossRef] 
228. Chatterjee, A. The neuropsychology of visual art: Conferring capacity. Int. Rev. Neurobiol. 2006, 74, 39-49.

229. Chatterjee, A. Prospects for a neuropsychology of art. In Neuroaesthetics; Skov, M., Vartanian, O., Eds.; Baywood Publishing: New York, NY, USA, 2009; pp. 131-143.

230. Miller, B.; Hou, C. Portraits of artists: Emergence of visual creativity in dementia. Arch. Neurol. 2004, 61, 842-844. [CrossRef]

231. Bogousslavsky, J. Artistic creativity, style and brain disorders. Eur. Neurol. 2005, 54, 103-111. [CrossRef]

232. Dirican, A.C.; Göktürk, M. Psychophysiological measures of human cognitive states applied in human computer interaction. Procedia Comput. Sci. 2011, 3, 1361-1367. [CrossRef]

233. Ray, W.J.; Oathes, D. Brain imaging techniques. Int. J. Clin. Exp. Hypn. 2003, 51, 97-104. [CrossRef]

234. Fairhall, S.L.; Ishai, A. Neural correlates of object indeterminacy in art compositions. Conscious. Cogn. 2008, 17, 923-932. [CrossRef]

235. Ishai, A.; Fairhall, S.L.; Pepperell, R. Perception, memory and aesthetics of indeterminate art. Brain Res. Bull. 2007, 73, 319-324. [CrossRef]

236. Bagozzi, R.P. The role of psychophysiology in consumer research. In Handbook of Consumer Behavior; Robertson, T.S., Kassarjian, H.H., Eds.; Prentice-Hall: Englewood Cliffs, NJ, USA, 1991; pp. 124-161.

237. Soares, J.M.; Magalhães, R.; Moreira, P.S.; Sousa, A.; Ganz, E.; Sampaio, A.; Alves, V.; Marques, P.; Sousa, N. A hitchhiker's guide to functional magnetic resonance imaging. Front. Neurosci. 2016, 10, 515. [CrossRef] [PubMed]

238. Thibault, R.T.; MacPherson, A.; Lifshitz, M.; Roth, R.R.; Raz, A. Neurofeedback with fMRI: A critical systematic review. Neuroimage 2018, 172, 786-807. [CrossRef]

239. Cohen, M.X. Where Does EEG Come from and What Does It Mean? Trends Neurosci. 2017, 40, 208-218. [CrossRef] [PubMed]

240. Mohammadi, Z.; Frounchi, J.; Amiri, M. Wavelet-based emotion recognition system using EEG signal. Neural Comput. 2017, 28, 1985-1990. [CrossRef]

241. Yao, D.; Qin, Y.; Hu, S.; Dong, L.; Vega, M.L.B.; Sosa, P.A.V. Which Reference Should We Use for EEG and ERP practice? Brain Topogr. 2019, 32, 530-549. [CrossRef] [PubMed]

242. Lotte, F.; Bougrain, L.; Cichocki, A.; Clerc, M.; Congedo, M.; Rakotomamonjy, A.; Yger, F. A review of classification algorithms for EEG-based brain-computer interfaces: A 10 year update. J. Neural Eng. 2018, 15, 31005. [CrossRef] [PubMed]

243. Boto, E.; Holmes, N.; Leggett, J.; Roberts, G.; Shah, V.; Meyer, S.S.; Duque, L.; Mullinger, K.J.; Tierney, T.M.; Bestmann, S.; et al Moving magnetoencephalography towards real-world applications with a wearable system. Nature 2018, 555, 657-661. [CrossRef]

244. Pu, Y.; Cheyne, D.O.; Cornwell, B.R.; Johnson, B.W. Non-invasive investigation of human hippocampal rhythms using magnetoencephalography: A review. Front. Neurosci. 2018, 12, 273. [CrossRef]

245. Valero-Cabré, A.; Amengual, J.L.; Stengel, C.; Pascual-Leone, A.; Coubard, O.A. Transcranial magnetic stimulation in basic and clinical neuroscience: A comprehensive review of fundamental principles and novel insights. Neurosci. Biobehav. Rev. 2017, 83, 381-404. [CrossRef] [PubMed]

246. Boucsein, W. Electrodermal Activity, 2nd ed.; Springer Science \& Business Media: Newbury Park, NY, USA; London, UK; New Dehli, India, 2012.

247. Dawson, M.E.; Schell, A.M.; Filion, D.L. The electrodermal system. In Handbook of Psychophysiology; Cacioppo, J.T., Tassinary, L.G., Berntson, G.G., Eds.; University Press: Cambridge, UK, 2007; pp. 159-181.

248. Benedek, M.; Kaernbach, C. A continuous measure of phasic electrodermal activity. J. Neurosci. Methods 2010, 190, 80-91. [CrossRef]

249. Raskin, D.C. Attention and Arousal. In Electrodermal Activity in Psychological Research; Prokasy, W.F., Raskin, D.C., Eds.; Academic Press: London, UK, 1973; pp. 123-156.

250. Goldman, M. Principles of Clinical Electrocardiography; LANGE: Los Altos, CA, USA, 1976.

251. Berntson, G.G.; Bigger, J.T.; Eckberg, D.L.; Grossman, P.; Kaufmann, P.G.; Malik, M. Heart rate variability: Origins, methods, and interpretive caveats. Psychophysiology 1997, 34, 623-648. [CrossRef]

252. Kim, H.G.; Cheon, E.J.; Bai, D.S.; Lee, Y.H.; Koo, B.H. Stress and heart rate variability: A meta-analysis and review of the literature. Psychiatry Investig. 2018, 15, 235. [CrossRef]

253. Laeng, B.; Sirois, S.; Gredebäck, G. Pupillometry: A Window to the Preconscious? Perspect. Psychol. Sci. 2012, 7, 18-27. [CrossRef]

254. Hess, E.H.; Polt, J.M. Pupil size as related to interest value of visual stimuli. Science 1960, 132, 349-350. [CrossRef]

255. Granholm, E.; Steinhauer, S.R. Pupillometric measures of cognitive and emotional processes. Int. J. Psychophysiol. 2004, 52, 1-6. [CrossRef]

256. Di Dio, C.; Gallese, V. Neuroaesthetics: A review. Curr. Opin. Neurobiol. 2009, 19, 682-687.

257. Kreibig, S.D. Autonomic nervous system activity in emotion: A review. Biol. Psychol. 2010, 84, 394-421. [CrossRef]

258. Duchowski, A. Eye tracking Methodology: Theory and Practice; Springer Science \& Business Media: London, UK, 2003.

259. Schofield, C.A.; Johnson, A.L.; Inhoff, A.W.; Coles, M.E. Social anxiety and difficulty disengaging threat: Evidence from eye-tracking. Cogn. Emot. 2012, 26, 300-3011. [CrossRef]

260. Holmqvist, K.; Nyström, M.; Andersson, R.; Dewhurst, R.; Jarodzka, H.; Van de Weijer, J. Eye Tracking: A Comprehensive Guide to Methods and Measures; Oxford University Press: London, UK, 2011.

261. Meißner, M.; Oll, J. The promise of eye-tracking methodology in organizational research: A taxonomy, review, and future avenues. Organ. Res. Methods 2019, 22, 590-617. [CrossRef]

262. Kamen, G. Electromyographic Kinesiology. In Research Methods in Biomechanics; Robertson, D.G.E., Caldwell, G.E., Hamill, J., Kamen, G., Whittlesey, S.N., Eds.; Human Kinetics: Leeds, UK, 2004. 
263. Ekman, P.; Friesen, W.V. Constants across cultures in the face and emotion. J. Pers. Soc. Psychol. 1971, 17, 124-129. [CrossRef]

264. Sato, W.; Fujimura, T.; Suzuki, N. Enhanced facial EMG activity in response to dynamic facial expressions. Int. J. Psychophysiol. 2008, 70, 70-74. [CrossRef]

265. Larsen, J.T.; Norris, C.J.; Cacioppo, J.T. Effects of positive and negative affect on electromyographic activity over zygomaticus major and corrugator supercilii. Psychophysiology 2003, 40, 776-785. [CrossRef]

266. Wolf, K.; Mass, R.; Ingenbleek, T.; Kiefer, F.; Naber, D.; Wiedemann, K. The facial pattern of disgust, appetence, excited joy and relaxed joy: An improved facial EMG study. Scand. J. Psychol. 2005, 46, 403-409. [CrossRef]

267. Calvo, M.G.; Nummenmaa, L. Perceptual and affective mechanisms in facial expression recognition: An integrative review. Cogn. Emot. 2016, 30, 1081-1106. [CrossRef]

268. Andreani, S.; Sayegh, A. Urban attractors, physical proximity and states of mind: Measuring dynamic experiences in varying typologies of the built environment. In Proceedings of the 2018 ANFA Conference; The Academy of Neuroscience for Architecture: La Jolla, CA, USA, 2018; pp. 10-11.

269. Kwon, J.; Kim, J. Individuals' visual attention to interior elements in the audio-visual context of lived experiences. In Proceedings of the 2018 ANFA Conference; The Academy of Neuroscience for Architecture: La Jolla, CA, USA, 2018; pp. 82-83.

270. Suurenbroek, F.; Spanjar, G. (Eye)tracking users' patterns: Visual experience and choice behavior in transition zones of AmsterdamSoutheast. In Proceedings of the 2018 ANFA Conference; The Academy of Neuroscience for Architecture: La Jolla, CA, USA, 2018; pp. 176-177.

271. Sussman, A. Using biometric software to understand the architectural experience and improve design. In Proceedings of the 2018 ANFA Conference; The Academy of Neuroscience for Architecture: La Jolla, CA, USA, 2018; pp. 184-185.

272. Chalup, S.K.; Hong, K.; Ostwald, M.J. Simulating pareidolia of faces for architectural image analysis. Int. J. Comput. Inf. Syst. Ind. Manag. Appl. 2010, 2, 262-278.

273. Frampton, K. Historia Crítica de la Arquitectura Moderna; Gustavo Gili: Barcelona, Spain, 2005.

274. de Kort, Y.A.W.; Ijsselsteijn, W.A.; Kooijman, J.; Schuurmans, Y. Virtual laboratories: Comparability of real and virtual environments for environmental psychology. Presence Teleoperators Virtual Environ. 2003, 12, 360-373. [CrossRef]

275. Lange, E. The limits of realism: Perceptions of virtual landscapes. Landsc. Urban Plan. 2001, 54, 163-182. [CrossRef]

276. Steuer, J. Defining Virtual Reality: Dimensions determining telepresence. J. Commun. 1992, 42, 73-93. [CrossRef]

277. Xu, S.; Li, Z.; Salvendy, G. Individualization of Head-Related Transfer Function for Three-Dimensional Virtual Auditory Display: A Review. In Proceedings of the Virtual Reality; Shumaker, R., Ed.; Springer: Berlin/Heidelberg, Germany, 2007 ; pp. $397-407$.

278. Papale, P.; Chiesi, L.; Rampinini, A.C.; Pietrini, P.; Ricciardi, E. When neuroscience "touches" architecture: From hapticity to a supramodal functioning of the human brain. Front. Psychol. 2016, 7, 866. [CrossRef]

279. Rangaraju, N.; Terk, M. Framework for immersive visualization of building analysis data. In Proceedings of the Fifth International Conference on Information Visualisation; Banissi, E., Khosrowshahi, F., Sarfraz, M., Ursyn, A., Eds.; IEEE: London, UK, 2001; pp. 37-42.

280. Baños, R.M.; Botella, C.; Alcañiz, M.; Liaño, V.; Guerrero, B.; Rey, B. Immersion and emotion: Their impact on the sense of presence. Cyber Psychol. Behav. 2004, 7, 734-741. [CrossRef]

281. Slater, M.; Wilbur, S. A framework for immersive virtual environments (FIVE): Speculations on the role of presence in virtual environments. Presence Teleoperators Virtual Environ. 1997, 6, 603-616. [CrossRef]

282. Slobounov, S.M.; Ray, W.; Johnson, B.; Slobounov, E.; Newell, K.M. Modulation of cortical activity in 2D versus 3D virtual reality environments: An EEG study. Int. J. Psychophysiol. 2015, 95, 254-260. [CrossRef]

283. Churchill, E.F.; Snowdon, D. Collaborative virtual environments: An introductory review of issues and systems. Virtual Real. 1998, 3, 3-15. [CrossRef]

284. Parsons, T.D. Virtual Reality for enhanced ecological validity and experimental control in the clinical, affective and social neurosciences. Front. Hum. Neurosci. 2015, 9, 660. [CrossRef]

285. Paranandi, M.; Sarawgi, T. Virtual Reality in Architecture: Enabling possibilities. In Proceedings of the 7th International Conference on ComputerAided Architectural Design Research in Asia (CAADRIA 2002); Moham Eshaq, A.R., Chee, W.K., Mai, N., Ken, T.K.N., Sharifah Nur, A.S.A., Eds.; CAADRIA: Cyberjaya, Malaysia, 2002; pp. 309-316.

286. Morganti, F.; Carassa, A.; Geminiani, G. Planning optimal paths: A simple assessment of survey spatial knowledge in virtual environments. Comput. Hum. Behav. 2007, 23, 1982-1996. [CrossRef]

287. McCall, C.; Hildebrandt, L.K.; Hartmann, R.; Baczkowski, B.M.; Singer, T. Introducing the Wunderkammer as a tool for emotion research: Unconstrained gaze and movement patterns in three emotionally evocative virtual worlds. Comput. Hum. Behav. 2016, 59, 93-107. [CrossRef]

288. Díaz Levicoy, D. TIC en Educación Superior: Ventajas y desventajas. Educ. Tecnol. 2014, 4, 44-50.

289. Zhang, L.; Chi, Y.M.; Edelstein, E.; Schulze, J.; Gramann, K.; Velasquez, A.; Cauwenberghs, G.; Macagno, E. Wireless physiological monitoring and ocular tracking: 3D calibration in a fully-immersive virtual health care environment. In Proceedings of the 32rd Annual international conference of the IEEE, Engineering in Medicine and Biology Society (EMBC), Buenos Aires, Argentina, 31 August-4 September 2010; IEEE: Buenos Aires, Argentina, 2010; pp. 4464-4467. 
290. Higuera-Trujillo, J.L.; Marin-Morales, J.; Rojas, J.; López-Tarruella, J.; Llinares, C.; Guixeres, J.; Alcañíz, M. Emotional cartography in design: A novel technique to represent emotional states altered by spaces. In DEE 2016-10th Internacional Conference on Design $\mathcal{E}$ Emotion; Desmet, P., Fokkinga, S., Ludden, G., Cila, N., van Zuthem, H., Eds.; The Design \& Emotion Society: Amsterdam, The Netherlands, 2016; pp. 561-586.

291. Hobbs, H.; Hunker, K.; Demircay, V.; Rodriquez, T.; Issa, R. A Preference study among four interior architectural geometries in a semi-immersive virtual environment. In Proceedings of the 2014 ANFA Conference; Albright, T., Cooke, G., Marks, F., Whitelaw, A., Macagno, E., Eds.; The Academy of Neuroscience for Architecture: La Jolla, CA, USA, 2014; pp. 52-53.

292. Frost, P.; Warren, P. Virtual reality used in a collaborative architectural design process. In IEEE International Conference on Information Visualization. An International Conference on Computer Visualization and Graphics 2000; Banissi, E., Bannatyne, M., Chen, C., Khosrowshahi, F., Sarfraz, M., Ursyn, A., Eds.; Practical, Interactive Institute Malmö University: Malmö, Sweden, 2000; pp. 568-573.

293. Cazorla, M.P.; Fiel, M.V.; Sanjuán, L.M.; Miralles, F.F. Representaciones virtuales y otros recursos técnicos en la accesibilidad al patrimonio cultural. EGA. Expresión Gráfica Arquit. 2011, 16, 164-173.

294. Stevenson, C.; Runyon, S.; Schulze, J.; Cauwenberghs, G.; Rafii, M.; Macagno, E. Virtual environments to assess facility design for the cognitively impaired. In Proceedings of the 2014 ANFA Conference; Albright, T., Cooke, G., Marks, F., Whitelaw, A., Macagno, E., Eds.; The Academy of Neuroscience for Architecture: La Jolla, CA, USA, 2014; pp. 98-99.

295. Conroy, R. Spatial Navigation in Immersive Virtual Environments. Ph.D. Thesis, University College London, London, UK, 2001.

296. Smith, S.P.; Trenholme, D. Rapid prototyping a virtual fire drill environment using computer game technology. Fire Saf. J. 2009, 44, 559-569. [CrossRef]

297. LaViola, J.J.; Kruijff, E.; McMahan, R.P.; Bowman, D.; Poupyrev, I.P. 3D User Interfaces: Theory and Practice; Addison-Wesley Professional: Boston, MA, USA, 2017.

298. Bliss, J.P.; Tidwell, P.D.; Guest, M.A. The Effectiveness of Virtual Reality for Administering Spatial Navigation Training to Firefighters. Presence Teleoperators Virtual Environ. 1997, 6, 73-83. [CrossRef]

299. Napieralski, P.E.; Altenhoff, B.M.; Bertrand, J.W.; Long, L.O.; Babu, S.V.; Pagano, C.C.; Davis, T.A. An evaluation of immersive viewing on spatial knowledge acquisition in spherical panoramic environments. Virtual Real. 2014, 18, 189-201. [CrossRef]

300. Richardson, A.E.; Montello, D.R.; Hegarty, M. Spatial knowledge acquisition from maps and from navigation in real and virtual environments. Mem. Cognit. 1999, 27, 741-750. [CrossRef]

301. van der Ham, I.J.M.; Faber, A.M.E.; Venselaar, M.; van Kreveld, M.J.; Löffler, M. Ecological validity of virtual environments to assess human navigation ability. Front. Psychol. 2015, 6, 1-6. [CrossRef]

302. Bozgeyikli, E.; Bozgeyikli, L.; Raij, A.; Katkoori, S.; Alqasemi, R.; Dubey, R. Virtual Reality Interaction Techniques for Individuals with Autism Spectrum Disorder: Design Considerations and Preliminary Results, Proceedings of the HCI International 2016 Conference; Springer: Toronto, ON, Canada, 2016; pp. 127-137.

303. Tregillus, S.; Al Zayer, M.; Folmer, E. Handsfree omnidirectional VR navigation using head tilt. In Proceedings of the $2017 \mathrm{CHI}$ Conference on Human Factors in Computing Systems; ACM: Denver, CO, USA, 2017; pp. 4063-4068.

304. Nescher, T.; Huang, Y.-Y.; Kunz, A. Planning redirection techniques for optimal free walking experience using model predictive control. In Proceedings of the 2014 IEEE Symposium on 3D User Interfaces (3DUI); Atlanta, GA, USA, 2014; pp. 111-118.

305. Nabiyouni, M.; Saktheeswaran, A.; Bowman, D.A.; Karanth, A. Comparing the performance of natural, semi-natural, and non-natural locomotion techniques in virtual reality. In Proceedings of the 2015 IEEE Symposium on 3D User Interfaces (3DUI), Arles, France, 23-24 March 2015; pp. 3-10.

306. Bozgeyikli, E.; Raij, A.; Katkoori, S.; Dubey, R. Locomotion in Virtual Reality for Individuals with Autism Spectrum Disorder. In Proceedings of the 2016 Symposium on Spatial User Interaction; Association for Computing Machinery, Tokyo, Japan, 15-16 October 2016; pp. 33-42.

307. Lee, J.; Ahn, S.; Hwang, J.I. A Walking-in-Place Method for Virtual Reality Using Position and Orientation Tracking. Sensors 2018, 18, 2832. [CrossRef]

308. Hendrix, C.; Barfield, W. Presence within virtual environments as a function of visual display parameters. Presence Teleoperators Virtual Environ. 1996, 5, 290-301. [CrossRef]

309. Kimura, K.; Reichert, J.F.; Olson, A.; Pouya, O.R.; Wang, X.; Moussavi, Z.; Kelly, D.M. Orientation in virtual reality does not fully measure up to the real-world. Sci. Rep. 2017, 7, 1-8. [CrossRef]

310. Ni, T.; Bowman, D.A.; Chen, J. Increased display size and resolution improve task performance in information-rich virtual environments. In GI '06 Proceedings of Graphics Interface 2006; Mann, S., Gutwin, C., Eds.; Canadian Information Processing Society: Quebec, QC, Canada, 2006; pp. 139-146.

311. Sharples, S.; Cobb, S.; Moody, A.; Wilson, J.R. Virtual Reality induced symptoms and effects (VRISE): Comparison of head mounted display (HMD), desktop and projection display systems. Displays 2008, 29, 58-69. [CrossRef]

312. Ellis, S.R. Nature and origin of virtual environments: A bibliographical essay. Comput. Syst. Eng. 1991, 2, 312-346. [CrossRef]

313. Hughes, J.F.; Van Dam, A.; Foley, J.D.; Feiner, S.K. Computer Graphics: Principles and Practice; Addison-Wesley: Boston, MA, USA, 1990.

314. Moscoso, C.; Matusiak, B.; Svensson, U.P.; Orleanski, K. Analysis of stereoscopic images as a new method for daylighting studies. ACM Trans. Appl. Percept. 2015, 11, 21. [CrossRef] 
315. Wood, D.; Fels, J. The natures of maps: Cartographic constructions of the natural world. Cartogr. Int. J. Geogr. Inf. Geovisualization 2008, 43, 189-202. [CrossRef]

316. Rohrmann, B.; Bishop, I.D. Subjective responses to computer simulations of urban environments. J. Environ. Psychol. 2002, 22, 319-331. [CrossRef]

317. Higuera-Trujillo, J.L.; López-Tarruella, J.; Llinares Millán, C. Psychological and physiological human responses to simulated and real environments: A comparison between Photographs, $360^{\circ}$ Panoramas, and Virtual Reality. Appl. Ergon. 2017, 65, 398-409. [CrossRef]

318. Rapoport, A. Facts and Models. In Design Methods in Architecture; Broadbent, G., Ward, A., Eds.; London, UK, 1969 ; pp. $136-146$.

319. Shields, J.A.E. Comparing physiological responses to modes of spatial representation. In Proceedings of the 2018 ANFA Conference; The Academy of Neuroscience for Architecture: La Jolla, CA, USA, 2018; pp. 164-165.

320. Lombard, M. Direct responses to people on the screen: Television and personal space. Communic. Res. 1995, 22, 288-324. [CrossRef]

321. Duarte, E.; Rebelo, F.; Wogalter, M.S. Virtual reality and its potential for evaluating warning compliance. Hum. Factors Ergon. Manuf. Serv. Ind. 2010, 20, 526-537. [CrossRef]

322. Hemeida, F.A.E.; Mostafa, H.H. Neuro architectural design. Int. J. Parallel Emergent Distrib. Syst. 2017, 32, S173-S179. [CrossRef]

323. Bohil, C.J.; Alicea, B.; Biocca, F.A. Virtual reality in neuroscience research and therapy. Nat. Rev. Neurosci. 2011, 12, 752-762. [CrossRef]

324. Cho, M.E.; Kim, M.J. Measurement of user emotion and experience in interaction with space. J. Asian Archit. Build. Eng. 2017, 16, 99-106. [CrossRef]

325. Ergan, S.; Radwan, A.; Zou, Z.; Tseng, H.A.; Han, X. Quantifying Human Experience in Architectural Spaces with Integrated Virtual Reality and Body Sensor Networks. J. Comput. Civ. Eng. 2019, 33, 04018062. [CrossRef]

326. Merril, J.R. Using emerging technologies such as virtual reality and the World Wide Web to contribute to a richer understanding of the brain. Ann. N. Y. Acad. Sci. 1997, 820, 229-233. [CrossRef]

327. Radwan, A.; Ergan, S. Quantifying human experience in interior architectural spaces. In Proceedings of the Computing in Civil Engineering 2017; Lin, K., El-Gohary, N., Tang, P., Eds.; ASCE: Seattle, WA, USA, 2017; pp. 373-380.

328. Riva, G. Virtual environments in clinical psychology. Psychother. Theory Res. Pract. Train. 2003, 40, 68-76. [CrossRef]

329. Rizzo, A.A.; Schultheis, M.; Kerns, K.A.; Mateer, C. Analysis of assets for virtual reality applications in neuropsychology. Neuropsychol. Rehabil. 2004, 14, 207-239. [CrossRef]

330. Tarr, M.J.; Warren, W.H. Virtual reality in behavioral neuroscience and beyond. Nat. Neurosci. 2002, 5, 1089-1092. [CrossRef]

331. Jelić, A.; Tieri, G.; De Matteis, F.; Babiloni, F.; Vecchiato, G. The Enactive Approach to Architectural Experience: A Neurophysiological Perspective on Embodiment, Motivation, and Affordances. Front. Psychol. 2016, 7, 1-20. [CrossRef]

332. Pasqualini, I.; Llobera, J.; Blanke, O. The 'I' of architectonic perception. In Proceedings of the ANFA Conference-Poster Session; Academy of Neuroscience for Architecture: La Jolla, CA, USA, 2012.

333. Sanchez-Vives, M.V.V.; Slater, M. From presence to consciousness through Virtual Reality. Nat. Rev. Neurosci. 2005, 6, 332-339. [CrossRef]

334. Ghahramani, Z.; Wolpert, D.M. Modular decomposition in visuomotor learning. Nature 1997, 386, 392-395. [CrossRef]

335. Aguirre, G.K.; Detre, J.A.; Alsop, D.C.; D’Esposito, M. The parahippocampus subserves topographical learning in man. Cereb. Cortex 1996, 6, 823-829. [CrossRef]

336. Pugnetti, L.; Mendozzi, L.; Motta, A.; Cattaneo, A.; Barbieri, E.; Brancotti, A. Evaluation and retraining of adults' cognitive impairments: Which role for virtual reality technology? Comput. Biol. Med. 1995, 25, 213-227. [CrossRef]

337. Slater, M.; Guger, C.; Edlinger, G.; Leeb, R.; Pfurtscheller, G.; Antley, A.; Garau, M.; Brogni, A.; Friedman, D. Analysis of physiological responses to a social situation in an immersive virtual environment. Presence Teleoperators Virtual Environ. 2006, 15, 553-569. [CrossRef]

338. Berka, C.; Pojmani, N.; Coyne, J.J.; Cole, A.; Denise, C. Neurogaming: Merging Cognitive Neuroscience \& Virtual Simulation in an Interactive Training Platform. In Advances in Understanding Human Performance. Neuroergonomics, Human Factors Design, and Special Populations; Marek, T., Karwowski, W., Valerie, R., Eds.; CRC Press: Boca Raton, FL, USA, 2010; pp. $313-324$.

339. Azevedo, A.S.; Jorge, J.; Campos, P. Combining EEG data with place and plausibility responses as an approach to measuring presence in outdoor virtual environments. Presence Teleoperators Virtual Environ. 2014, 23, 354-368. [CrossRef]

340. McCall, C.; Hildebrandt, L.K.; Bornemann, B.; Singer, T. Physiophenomenology in retrospect: Memory reliably reflects physiological arousal during a prior threatening experience. Conscious Cogn. 2015, 38, 60-70. [CrossRef]

341. Bian, Y.; Yang, C.; Gao, F.; Li, H.; Zhou, S.; Li, H.; Sun, X.; Meng, X. A framework for physiological indicators of flow in VR games: Construction and preliminary evaluation. Pers. Ubiquitous Comput. 2016, 20, 821-832. [CrossRef]

342. Chittaro, L.; Sioni, R.; Crescentini, C.; Fabbro, F. Mortality salience in virtual reality experiences and its effects on users' attitudes towards risk. J. Hum.-Comput. Stud. 2017, 101, 10-22. [CrossRef]

343. Kisker, J.; Gruber, T.; Schöne, B. Behavioral realism and lifelike psychophysiological responses in virtual reality by the example of a height exposure. Psychol. Res. 2019, 1-14. [CrossRef]

344. Biedermann, S.V.; Biedermann, D.G.; Wenzlaff, F.; Kurjak, T.; Nouri, S.; Auer, M.K.; Wiedemann, K.; Briken, P.; Haaker, J.; Lonsdorf, T.B.; et al. An elevated plus-maze in mixed reality for studying human anxiety-related behavior. BMC Biol. 2017, 15, 125. [CrossRef] 
345. Tsai, C.-F.; Yeh, S.-C.; Huang, Y.; Wu, Z.; Cui, J.; Zheng, L. The Effect of Augmented Reality and Virtual Reality on Inducing Anxiety for Exposure Therapy: A Comparison Using Heart Rate Variability. J. Healthc. Eng. 2018, 2018, 6357351. [CrossRef]

346. Zimmer, P.; Wu, C. Same but different? Replicating the real surroundings in a virtual Trier Social Stress Test (TSST-VR) does not enhance presence or the psychophysiological stress response. Physiol. Behav. 2019, 212, 112690. [CrossRef]

347. Lin, J.; Cao, L.; Li, N. Assessing the influence of repeated exposures and mental stress on human wayfinding performance in indoor environments using virtual reality technology. Adv. Eng. Inform. 2019, 39, 53-61. [CrossRef]

348. Peperkorn, H.M.; Alpers, G.W.; Mühlberger, A. Triggers of fear: Perceptual cues versus conceptual information in spider phobia. J. Clin. Psychol. 2014, 70, 704-714. [CrossRef]

349. Gromer, D.; Reinke, M.; Christner, I.; Pauli, P. Causal Interactive Links between Presence and Fear in Virtual Reality Height Exposure. Front. Psychol. 2019, 10, 141. [CrossRef]

350. Chiamulera, C.; Ferrandi, E.; Benvegnù, G.; Ferraro, S.; Tommasi, F.; Maris, B.; Zandonai, T.; Bosi, S. Virtual reality for neuroarchitecture: Cue reactivity in built spaces. Front. Psychol. 2017, 8, 185. [CrossRef]

351. Chatterjee, A. The Aesthetic Brain: How We Evolved to Desire Beauty and Enjoy Art; Oxford University Press: New York, NY, USA, 2013.

352. Shimamura, A. Experiencing Art: In the Brain of the Beholder; Oxford University Press: New York, NY, USA, 2013.

353. Biren, A. Spatial manifestations of the Human Psyche: Architecture based on neurological theories of aesthetic experience \& environmental preference. In Proceedings of the 2014 ANFA Conference; Albright, T., Cooke, G., Marks, F., Whitelaw, A., Macagno, E., Eds.; The Academy of Neuroscience for Architecture: La Jolla, CA, USA, 2014; pp. 20-21.

354. Reimann, M.; Zaichkowsky, J.; Neuhaus, C.; Bender, T.; Weber, B. Aesthetic package design: A behavioral, neural, and psychological investigation. J. Consum. Psychol. 2010, 20, 431-441. [CrossRef]

355. Halit, H.; de Hann, M.; Johnston, M.H. Modulation of event-related potentials by prototypical and atypical faces. Neuroreport 2000, 11, 1871-1875. [CrossRef]

356. Martindale, C.; Moore, K. Priming, prototypicality, and preference. J. Exp. Psychol. Hum. Percept. Perform. 1988, 14, 661-670. [CrossRef]

357. Postrel, V. The Substance of Style; HarperCollins: New York, NY, USA, 2003.

358. Ramachandran, V.S.; Hirstein, W. The Science of Art: A Neurological Theory of Aesthetic Experience. J. Conscious. Stud. 1999, 6-7, 15-51.

359. Frey, D. Zum Problem der Symmetrie in der bildenden Kunst. Stud. Gen. 1949, 2, 268-278.

360. Gombrich, E.H. The Sense of Order; Phaidon: London, UK, 1984.

361. Frith, C.D.; Nias, D.K.B. What determines aesthetic preferences? J. Gen. Psychol. 1974, 91, 163-173. [PubMed]

362. Rentschler, I.; Jüttner, M.; Unzicker, A.; Landis, T. Innate and learned components of human visual preference. Curr. Biol. 1999, 9 , 665-671. [CrossRef]

363. Baudouin, J.Y.; Tiberghien, G. Symmetry, averageness, and feature size in the facial attractiveness of women. Acta Psychol. 2004, 117, 313-332. [CrossRef]

364. Rhodes, G.; Proffitt, F.; Grady, J.M.; Sumich, A. Facial symmetry and the perception of beauty. Psychon. Bull. Rev. 1998, 5, 659-669. [CrossRef]

365. Weyl, H. Symmetry; Princeton University Press: Princeton, NJ, USA, 2016.

366. Goldberg, E.; Funk, B.A.; Podell, K. How the brain deals with novelty and ambiguity: Implications for neuroaesthetics. Rend. Lincei 2012, 23, 227-238. [CrossRef]

367. Julesz, B. Foundations of Cyclopean perception; Chicago University Press: Chicago, IL, USA, 1971.

368. Locher, P.; Nodine, C. Symmetry Catches the Eye. In Eye movements: From Physiology to Cognition; O’Regan, J.K., Levy-Schoen, A., Eds.; Elsevier: Amsterdam, The Netherlands, 1987; pp. 353-361.

369. Arnheim, R. New Essays on the Psychology of Art; University of California Press: Berkeley, CA, USA, 1986.

370. Höfel, L.; Jacobsen, T. Electrophysiological indices of processing symmetry and aesthetics: A result of judgment categorization or judgment report? J. Psychophysiol. 2007, 21, 9-21. [CrossRef]

371. Arnheim, R. The Power of the Center: A Study of Composition in The Visual Arts; University of California Press: London, UK, 1982.

372. Firstov, V.; Firstov, V.; Voloshinov, A.; Locher, P. The colorimetric barycenter of paintings. Empir. Stud. Arts 2007, 25, 209-2017. [CrossRef]

373. Jalil, N.A.; Yunus, R.M.; Said, N.S. Environmental Colour Impact upon Human Behaviour: A Review. Procedia-Soc. Behav. Sci. 2012, 35, 54-62. [CrossRef]

374. Aminoff, E.; Gronau, N.; Bar, M. The parahippocampal cortex mediates spatial and non-spatial associations. Cereb. Cortex 2007, 17, 1493-1503. [CrossRef]

375. Biaggio, M.K.; Supplee, K.A. Dimensions of aesthetic perception. J. Psychol. 1983, 114, 29-35. [CrossRef]

376. Popper, K. Simplicity. In The Logic of Scientific Discovery; Routledge: London, UK, 1992.

377. Berlyne, D.E. Novelty, Complexity, and Hedonic Value. Percept. Psychophys. 1970, 8, 279-286. [CrossRef]

378. Berlyne, D.E. Studies in the New Experimental Aesthetics: Steps toward an Objective Psychology of Aesthetic Appreciation; Hemisphere: Oxford, UK, 1974.

379. Helson, H. Adaptation-Level Theory: An Experimental and Systematic Approach to Behavior; Harper and Row: New York, NY, USA, 1964. 
380. Spehar, B.; Clifford, C.W.; Newell, B.R.; Taylor, R.P. Universal aesthetic of fractals. Comput. Graph. 2003, 27, 813-820. [CrossRef]

381. Abboushi, B.; Elzeyadi, I.; Taylor, R.; Sereno, M. Fractals in architecture: The visual interest, preference, and mood response to projected fractal light patterns in interior spaces. J. Environ. Psychol. 2019, 61, 57-70. [CrossRef]

382. Taylor, R.P.; Spehar, B.; Wise, J.A.; Clifford, C.W.; Newell, B.R.; Hagerhall, C.M.; Puncell, T.; Martin, T.P. Perceptual and physiological responses to the visual complexity of fractal patterns. Nonlinear Dyn. Psychol. Life Sci. 2005, 9, 89-114.

383. Shermer, M. The Believing Brain; MacMillan: New York, NY, USA, 2011.

384. Kandel, E. Reductionism in Art and Brain Science: Bridging the Two Cultures; Columbia University Press: New York, NY, USA, 2016.

385. Bar, M. Visual objects in context. Nat. Rev. Neurosci. 2004, 5, 617-629. [CrossRef]

386. Fenske, M.J.; Aminoff, E.; Gronau, N.; Bar, M. Top-down facilitation of visual object recognition: Object-based and context-based contributions. Prog. Brain Res. 2006, 155, 3-21.

387. Brieber, D.; Nadal, M.; Leder, H.; Rosenberg, R. Art in Time and Space: Context Modulates the Relation between Art Experience and Viewing Time. PLoS ONE 2014, 9, e99019. [CrossRef]

388. Goldstein, W.M.; Weber, E.U. Content and discontent: Indications and implications of domain specificity in preferential decision making. In Research on Judgment and Decision Making; Goldstein, W.M., Hogarth, R.M., Eds.; Cambridge University Press: Cambridge, UK, 1997; pp. 566-617.

389. Oliva, A.; Torralba, A. The role of context in object recognition. Trends Cogn. Sci. 2007, 11, 520-527. [CrossRef]

390. Zajonc, R.B. Feeling and thinking: Preferences need no inferences. Am. Psychol. 1980, 35, 151-175. [CrossRef]

391. Bar, M. The proactive brain: Using analogies and associations to generate predictions. Trends Cogn. Sci. 2007, 11, 280-289. [CrossRef] [PubMed]

392. Leder, H. Explorationen in der Bildästhetik; Pabst: Lengerich, Germany, 2002.

393. Reber, R.; Winkielman, P.; Schwarz, N. Effects of perceptual fluency on affective judgments. Psychol. Sci. 1998, 9, 45-48. [CrossRef]

394. Oliva, A.; Torralba, A. Building the gist of a scene: The role of global image features in recognition. In Progress in Brain Research; Martinez-Conde, S., Macknik, S.L., Martinez, L.M., Alonso, J.M., Tse, P.U., Eds.; Elsevier, 2006; Volume 155, pp. 23-36.

395. Zeki, S. The Neurology of Ambiguity. Conscious. Cogn. 2004, 13, 173-196. [CrossRef]

396. Simons, J.S.; Koutstaal, W.; Prince, S.; Wagner, A.D.; Schacter, D.L. Neural mechanisms of visual object priming: Evidence for perceptual and semantic distinctions in fusiform cortex. Neuroimage 2003, 19, 613-626. [CrossRef]

397. Kubovy, M. Visual aesthetics. In Encyclopedia of Psychology; Kazdin, A.E., Ed.; Oxford University Press: New York, NY, USA, 2000.

398. Munar, E.; Nadal, M.; Rosselló, J.; Flexas, A.; Moratti, S.; Maestú, F.; Marty, G.; Cela-Conde, C.J. Lateral Orbitofrontal Cortex Involvement in Initial Negative Aesthetic Impression Formation. PLoS ONE 2012, e38152. [CrossRef] [PubMed]

399. Zeki, S. Inner Vision: An Exploration of Art and the Brain; Oxford University Press: Oxford, UK, 1999.

400. Hagendoorn, I.G. Some speculative hypotheses about the nature and perception of dance and choreography. J. Conscious. Stud. 2004, 11, 79-110.

401. Konecni, V.J. Determinants of aesthetic preference and effects of exposure to aesthetic stimuli: Social emotional, and cognitive factors. Prog. Exp. Pers. Res. 1978, 9, 149-197.

402. Forgas, J.P. Mood and judgment: The Affect Infusion Model (AIM). Psychol. Bull. 1995, 117, 39-66. [CrossRef]

403. Bower, G.H. Mood and memory. Am. Psychol. 1981, 36, 129-148. [CrossRef] [PubMed]

404. Berlyne, D.E. Aesthetics and Psychobiology; Appleton-Century-Crofts: New York, NY, USA, 1971.

405. Kirk, U.; Skov, M.; Christensen, M.S.; Nygaard, N. Brain correlates of aesthetic expertise: A parametric fMRI study. Brain Cogn. 2009, 69, 306-315. [CrossRef]

406. Zajonc, R.B. Attitudinal effects of mere exposure. J. Pers. Soc. Psychol. 1968, 9, 1-27. [CrossRef]

407. Davenport, J.L.; Potter, M.C. Scene consistency in object and background perception. Psychol. Sci. 2004, 15, 559-564. [CrossRef] [PubMed]

408. Boyce, S.J.; Pollatsek, A.; Rayner, K. Effect of background information on object identification. J. Exp. Psychol. Hum. Percept. Perform. 1989, 15, 556-566. [CrossRef] [PubMed]

409. Biederman, I.; Vessel, E. Perceptual Pleasure and the Brain. Am. Sci. 2006, 94, 247-253. [CrossRef]

410. Supp, G.G.; Schlögl, A.; Trujillo-Barreto, N.; Müller, M.M.; Gruber, T. Directed cortical information flow during human object recognition: Analyzing induced EEG gamma-band responses in brain's source space. PLoS ONE 2007, 2, e684. [CrossRef]

411. Martinovic, J.; Gruber, T.; Müller, M.M. Induced gamma band responses predict recognition delays during object identification. J. Cogn. Neurosci. 2007, 19, 921-934. [CrossRef]

412. Keil, A.; Müller, M.M.; Ray, W.J.; Gruber, T.; Elbert, T. Human gamma band activity and perception of a Gestalt. J. Neurosci. 1999, 19, 7152-7161. [CrossRef]

413. Başar-Eroglu, C.; Strüber, D.; Kruse, P.; Başar, E.; Stadler, M. Frontal gamma-band enhancement during multistable visual perception. Int. J. Psychophysiol. 1996, 24, 113-125. [CrossRef]

414. Leder, H. Determinants of preference. When do we like what we know? Empir. Stud. Arts 2001, 19, 201-211. [CrossRef]

415. de Araujo, I.E.; Rolls, E.T.; Velazco, M.I.; Margot, C.; Cayeux, I. Cognitive modulation of olfactory processing. Neuron 2005, 46, 671-679. [CrossRef]

416. Ritterfeld, U. Social heuristics in interior design preferences. J. Environ. Psychol. 2002, 22, 369-386. [CrossRef]

417. Erk, S.; Spitzer, M.; Wunderlich, A.P.; Galley, L.; Walter, H. Cultural objects modulate reward circuitry. Neuroreport 2002, 13, 2499-2503. [CrossRef] 
418. Schaefer, M.; Rotte, M. Favorite brands as cultural objects modulate reward circuit. Neuroreport 2007, 18, 141-145. [CrossRef] [PubMed]

419. Plassmann, H.; O'Doherty, J.; Shiv, B.; Rangel, A. Marketing actions can modulate neural representations of experienced pleasantness. Proc. Natl. Acad. Sci. USA 2008, 105, 1050-1054. [CrossRef]

420. Gutchess, A.H.; Welsh, R.C.; Boduroĝlu, A.; Park, D.C. Cultural differences in neural function associated with object processing. Cogn. Affect. Behav. Neurosci. 2006, 6, 102-109. [CrossRef]

421. Chebat, J.C.; Morrin, M. Colors and Cultures: Exploring the Effects of Mall Décor on Consumer Perceptions. J. Bus. Res. 2007, 60, 189-196. [CrossRef]

422. Eysenck, H.J.; Hawker, G.W. The taxonomy of visual aesthetic preferences: An empirical study. Empir. Stud. Arts 1994, 12, 95-101. [CrossRef]

423. Gordon, P.C.; Holyoak, K.J. Implicit learning and generalisation of the 'mere exposure' effect. J. Pers. Soc. Psychol. 1983, 45, 492-500. [CrossRef]

424. Barron, F.; Welsh, G.S. Artistic perception as a possible factor in personality style: Its measurement by a figure preference test. J. Psychol. 1952, 33, 199-203. [CrossRef]

425. Hekkert, P.; van Wieringen, P.C.W. The impact of level of expertise on the evaluation of original and altered versions of post-impressionistic paintings. Acta Psychol. 1996, 94, 117-131. [CrossRef]

426. Hekkert, P.; van Wieringen, P.C.W. Beauty in the eye of expert and nonexpert beholders: A study in the appraisal of art. Am. J. Psychol. 1996, 109, 389-407. [CrossRef]

427. Winston, A.S.; Cupchik, G.C. The evaluation of high art and popular art by naive and experienced viewers. Vis. Arts Res. 1992, 18, $1-14$.

428. Iñarra, S.; Vidal, F.J.; Llinares, M.C.; Guixeres, J. Atención visual en la evaluación de espacios arquitectónicos. EGA. Expresión Gráfica Arquit. 2015, 20, 228-237. [CrossRef]

429. Müller, M.; Höfel, L.; Brattico, E.; Jacobsen, T. Electrophysiological correlates of aesthetic music processing. Ann. N. Y. Acad. Sci. 2009, 1169, 355-358. [CrossRef] [PubMed]

430. Vogt, S.; Magnussen, S. Expertise in pictorial perception: Eye-movement patterns and visual memory in artists and laymen Perception 2007, 36, 91-100. [CrossRef] [PubMed]

431. Bangert, M.; Peschel, T.; Schlaug, G.; Rotte, M.; Drescher, D.; Hinrichs, H. Shared networks for auditory and motor processing in professional pianists: Evidence from fMRI conjunction. Neuroimage 2006, 30, 917-926. [CrossRef] [PubMed]

432. Cela-Conde, C.J.; García-Prieto, J.; Ramasco, J.J.; Mirasso, C.R.; Bajo, R.; Munar, E.; Flexas, A.; del-Pozo, F.; Maestú, F. Dynamics of brain networks in the aesthetic appreciation. Proc. Natl. Acad. Sci. USA 2013, 110, 10454-10461. [CrossRef]

433. Farah, M. The Cognitive Neuroscience of Vision; Blackwell Publishers: Malden, MA, USA, 2000.

434. Marr, D. Vision, A. A Computational Investigation into the Human Representation and Processing of Visual Information; WH Freeman and Company: New York, NY, USA, 1982.

435. Jacobsen, T.; Höfel, L. Descriptive and evaluative judgment processes: Behavioral and electrophysiological indices of processing symmetry and aesthetics. Cogn. Affect. Behav. Neurosci. 2003, 3, 289-299. [CrossRef]

436. Blood, A.J.; Zatorre, R.J. Intensely pleasurable response to music correlate with activity in the brain regions implicated in reward and emotion. Proc. Natl. Acad. Sci. USA 2001, 92, 11818-11823. [CrossRef]

437. Wise, R.A.; Rompre, P.P. Brain dopamine and reward. Annu. Rev. Psychol. 1989, 40, 191-225. [CrossRef]

438. Schwartz, G.E.; Davidson, R.J.; Maer, F. Right hemisphere lateralization for emotion in the human brain: Interactions with cognition. Science 1975, 190, 286-288. [CrossRef]

439. Kosslyn, S.M. Seeing and imagining in the cerebral hemispheres: A computational approach. Psychol. Rev. 1987, 94, 148-175. [CrossRef]

440. Kirk, U.; Skov, M.; Hulme, O.; Christensen, M.S.; Zeki, S. Modulation of aesthetic value by semantic context: An fMRI study. Neuroimage 2009, 44, 1125-1132. [CrossRef]

441. Brown, S.; Gao, X.; Tisdelle, L.; Eickhoff, S.B.; Liotti, M. Naturalizing aesthetics: Brain areas for aesthetic appraisal across sensory modalities. Neuroimage 2011, 58, 250-258. [CrossRef] [PubMed]

442. Decety, J.; Jackson, P.L. The functional architecture of human empathy. Behav. Cogn. Neurosci. Rev. 2004, 3, 71-100. [CrossRef] [PubMed]

443. Freedberg, D.; Gallese, V. Motion, emotion and empathy in esthetic experience. Trends Cogn. Sci. 2007, 11, 197-203. [CrossRef] [PubMed]

444. Mallgrave, H.F. Architecture and Embodiment: The Implications of the New Sciences and Humanities for Design; Routledge: New York, NY, USA, 2013.

445. Serences, J.T.; Yantis, S. Selective visual attention and perceptual coherence. Trends Cogn. Sci. 2006, 10, 38-45. [CrossRef]

446. Lane, R.D.; Reiman, E.M.; Axelrod, B.; Yun, L.S.; Holmes, A.; Schwartz, G.E. Neural correlates of levels of emotional awareness: Evidence of an interaction between emotion and attention in the anterior cingulate cortex. J. Cogn. Neurosci. 1998, 10, 525-535. [CrossRef]

447. Ernst, L.H.; Weidner, A.; Ehlis, A.C.; Fallgatter, A.J. Controlled attention allocation mediates the relation between goal-oriented pursuit and approach-avoidance reactions to negative stimuli. Biol. Psychol. 2012, 91, 312-320. [CrossRef] 
448. Campbell-Sills, L.; Simmons, A.N.; Lovero, K.L.; Rochlin, A.A.; Paulus, M.P.; Stein, M.B. NeuroImage functioning of neural systems supporting emotion regulation in anxiety-prone individuals. Neuroimage 2011, 54, 689-696. [CrossRef]

449. Volle, E.; Gilbert, S.J.; Benoit, R.G.; Burgess, P.W. Specialization of the rostral prefrontal cortex for distinct analogy processes. Cereb. Cortex 2010, 20, 2647-2659. [CrossRef] [PubMed]

450. Kirino, E.; Belger, A.; Goldman-Rakic, P.; McCarthy, G. Prefrontal activation evoked by infrequent target and novel stimuli in a visual target detection task: An event-related functional magnetic resonance imaging study. J. Neurosci. 2000, 20, 6612-6618. [CrossRef] [PubMed]

451. Munar, E.; Nadal, M.; Castellanos, N.P.; Flexas, A.; Maestú, F.; Mirasso, C.; Cela-Conde, C.J. Aesthetic appreciation: Event-related field and time-frequency analyses. Front. Hum. Neurosci. 2011, 5, 185. [CrossRef]

452. Di Dio, C.; Macaluso, E.; Rizzolatti, G. The Golden Beauty: Brain Response to Classical and Renaissance Sculptures. PLoS Med. 2007, 2, e1201. [CrossRef] [PubMed]

453. Vartanian, O.; Goel, V. Neuroanatomical correlates of aesthetic preference for paintings. Neuroreport 2004, $15,893-897$. [CrossRef] [PubMed]

454. Ishizu, T.; Zeki, S. Toward a brain-based theory of beauty. PLoS ONE 2011, 6, e21852. [CrossRef]

455. Cela-Conde, C.J.; Marty, G.; Maestú, F.; Ortiz, T.; Munar, E.; Fernández, A.; Roca, M.; Rosselló, J.; Quesney, F. Activation of the prefrontal cortex in the human visual aesthetic perception. Proc. Natl. Acad. Sci. USA 2004, 101, 6321-6325. [CrossRef]

456. Francis, S.; Rolls, E.T.; Bowtell, R.; McGlone, F.; O’Doherty, J.; Browning, A.; Clare, S.; Smith, E. The representation of pleasant touch in the brain and its relationship with taste and olfactory areas. Neuroreport 1999, 10, 453-459. [CrossRef]

457. Small, D.M.; Gregory, M.D.; Mak, Y.E.; Gitelman, D.; Mesulam, M.M.; Parrish, T. Dissociation of neural representation of intensity and affective valuation in human gestation. Neuron 2003, 39, 701-711. [CrossRef]

458. Wallis, J.D. Orbitofrontal cortex and its contribution to decision-making. Annu. Rev. Neurosci. 2007, 30, 31-56. [CrossRef]

459. Kirk, U. The Neural Basis of Object-Context Relationships on Aesthetic Judgement. PLoS ONE 2008, e3754. [CrossRef] [PubMed]

460. Kringelbach, M.L.; Rolls, E.T. The functional neuroanatomy of the human orbitofrontal cortex: Evidence from neuroimaging and neuropsychology. Prog. Neurobiol. 2004, 72, 341-372. [CrossRef] [PubMed]

461. Tsukiura, T.; Cabeza, R. Shared brain activity for aesthetic and moral judgments: Implications for the Beauty-is-Good stereotype. Soc. Cogn. Affect. Neurosci. 2011, 6, 138-148. [CrossRef]

462. Zeki, S.; Stutters, J. A brain-derived metric for preferred kinetic stimuli. Open Biol. 2012, 2, 120001. [CrossRef]

463. Vessel, E.A.; Starr, G.G.; Rubin, N. The brain on art: Intense aesthetic experience activates the default mode network. Front. Hum. Neurosci. 2012, 6, 66. [CrossRef]

464. Kawabata, H.; Zeki, S. Neural correlates of beauty. J. Neurophysiol. 2004, 91, 1699-1705. [CrossRef]

465. Teasdale, J.D.; Howard, R.J.; Cox, S.G.; Ha, Y.; Brammer, M.J.; Williams, S.C.; Checkley, S.A. Functional MRI study of the cognitive generation of affect. Am. J. Psychiatry 1999, 156, 209-215. [PubMed]

466. de Tommaso, M.; Pecoraro, C.; Sardaro, M.; Serpino, C.; Lancioni, G.; Livrea, P. Influence of aesthetic perception on visual event-related potentials. Conscious. Cogn. 2008, 17, 933-945. [CrossRef]

467. Taylor, S.F.; Phan, K.L.; Decker, L.R.; Liberzon, I. Subjective rating of emotionally salient stimuli modulates neural activity. Neuroimage 2003, 18, 650-659. [CrossRef]

468. Kim, H.; Adolphs, R.; O’Doherty, J.P.; Shimojo, S. Temporal isolation of neural processes underlying face preference decisions. Proceedings of the National Academy of Sciences. Proc. Natl. Acad. Sci. USA 2007, 104, 18253-18258. [CrossRef]

469. Paradiso, S.; Johnson, D.L.; Andreasen, N.C.; O'Leary, D.S.; Watkins, G.L.; Boles Ponto, L.L.; Hichwa, R.D. Cerebral blood flow changes associated with attribution of emotional valence to pleasant, unpleasant, and neutral visual stimuli in a PET study of normal subjects. Am. J. Psychiatry 1999, 156, 1618-1629. [CrossRef]

470. Yue, X.; Vessel, E.A.; Biederman, I. The neural basis of scene preferences. Neuroreport 2007, 18, 525-529. [CrossRef]

471. Ishizu, T.; Zeki, S. The brain's specialized systems for aesthetic and perceptual judgment. Eur. J. Neurosci. 2013, 37, 1413-1420. [CrossRef]

472. Jacobsen, T.; Schubotz, R.I.; Höfel, L.; Cramon, D.Y.V. Brain correlates of aesthetic judgment of beauty. Neuroimage 2006, 29, 276-285. [CrossRef]

473. Small, D.M.; Zatorre, R.J.; Dagher, A.; Evans, A.C.; Jones-Gotman, M. Changes in brain activity related to eating chocolate. Brain 2001, 124, 1720-1733. [CrossRef]

474. Gottfried, J.A.; Deichmann, R.; Winston, J.S.; Dolan, R.J. Functional heterogeneity in human olfactory cortex: An event-related functional magnetic resonance imaging study. J. Neurosci. 2002, 22, 10819-10828. [CrossRef]

475. Delgado, M.; Nystrom, L.; Fissell, K.; Noll, D.; Fiez, J. Tracking the hemodynamic responses for reward and punishment. J. Neurophysiol. 2000, 84, 3072-3077. [CrossRef]

476. Iidaka, T.; Okada, T.; Murata, T.; Omori, M.; Kosaka, H.; Sadato, N.; Yonekura, Y. Age-related differences in the medial temporal lobe responses to emotional faces as revealed by fMRI. Hippocampus 2002, 12, 352-362. [CrossRef] [PubMed]

477. Salimpoor, V.N.; Benovoy, M.; Longo, G.; Larcher, K.; Cooperstock, J.; Dagher, A.; Zatorre, R.J. The rewarding aspects of music listening involve the dopaminergic striatal reward systems of the brain: An investigation with [C11]raclopride PET and fMRI. Neuroimage 2008, 47, S39-S41. [CrossRef]

478. Koelsch, S.; Fritz, T.; Müller, K.; Friederici, A.D. Investigating emotion with music: An fMRI study. Hum. Brain Mapp. 2006, 27, 239-250. [CrossRef] 
479. Koelsch, S.; Fritz, T.; Schlaug, G. Amygdala activity can be modulated by unexpected chord functions during music listening. Neuroreport 2008, 19, 1815-1819. [CrossRef] [PubMed]

480. Miller, M.; Clark, A. Happily entangled: Prediction, emotion, and the embodied mind. Synthesethese 2018, 195, 2559-2575. [CrossRef]

481. Cupchik, G.C.; Vartanian, O.; Crawley, A.; Mikulis, D.J. Viewing artworks: Contributions of cognitive control and perceptual facilitation to aesthetic experience. Brain Cogn. 2009, 70, 84-91. [CrossRef]

482. Leder, H.; Belke, B.; Oeberst, A.; Augustin, D. A model of aesthetic appreciation and aesthetic judgments. Br. J. Psychol. 2004, 95, 489-508. [CrossRef]

483. Chatterjee, A. Prospects for a Cognitive Neuroscience of Visual Aesthetics. Bull. Psychol. Arts 2004, 4, 56-60.

484. Coburn, A.; Vartanian, O.; Chatterjee, A. Buildings, beauty, and the brain: A neuroscience of architectural experience. J. Cogn. Neurosci. 2017, 29, 1521-1531. [CrossRef]

485. Nadal, M.; Munar, E.; Capó, M.À.; Rosselló, J.; Cela-Conde, C.J. Towards a framework for the study of the neural correlates of aesthetic preference. Spat. Vis. 2008, 21, 379-396.

486. Linaraki, D.; Voradaki, G. The Interaction of Space with the Human Nervous System and its Impact on Human Psychology. In Proceedings of the ANFA Conference-Poster Session; Academy of Neuroscience for Architecture: La Jolla, CA, USA, 2012.

487. Jelić, A. Designing "pre-reflective" architecture. Implications of neurophenomenology for architectural design and thinking. Ambiances 2015, 1. [CrossRef]

488. von Hayek, F.A. The Sensory Order; Chicago University Press: Chicago, IL, USA, 1952.

489. Arnheim, R. Art and Visual Perception: A Psychology of the Creative Eye; University of California Press: Berkeley, CA, USA, 2004.

490. Hebb, D.O. The Organisation of Behavior; Wiley: New York, NY, USA, 1949.

491. Neutra, R.J. Survival through Design; Oxford University Press: New York, NY, USA, 1954.

492. Moholy-Nagy, L. Von Material zu Architektur; Florian Kupferberg: Mainz, Germany, 1929.

493. Robinson, S.; Pallasmaa, J. Mind in Architecture: Neuroscience, Embodiment, and the Future of Design; MIT Press: Cambridge, MA, USA, 2015.

494. Varela, F.; Thompson, E.; Rosch, E. The Embodied Mind. Cognitive Science and Human Experience; MIT Press: London, UK, 2016.

495. Vijayan, V.T.; Embi, M.R. Probing phenomenological experiences through electroencephalography brainwave signals in neuroarchitecture study. Int. J. Built Environ. Sustain. 2019, 6, 11-20. [CrossRef]

496. Ulrich, R.S. Natural versus urban scenes: Some psychophysiological effects. Environ. Behav. 1981, 13, 523-556. [CrossRef]

497. Arbib, M.A. Toward a Neuroscience of the Design Process. In Mind in Architecture: Neuroscience, Embodiment, and the Future of Design; Robinson, S., Pallasmaa, J., Eds.; MIT Press: Cambridge, MA, USA, 2015; pp. 75-98.

498. Banasiak, M. Cultivating a culture for Neuro-Architecture. In Proceedings of the ANFA Conference-Poster Session; Academy of Neuroscience for Architecture: La Jolla, CA, USA, 2012.

499. Edelstein, E.A.; Sax, C.L. Diffusion of innovation: Neuroscience \& Architecture from Pedagogy to Practice. In Proceedings of the 2014 ANFA Conference; Albright, T., Cooke, G., Marks, F., Whitelaw, A., Macagno, E., Eds.; The Academy of Neuroscience for Architecture: La Jolla, CA, USA, 2014; pp. 32-33.

500. Manganelli, J.; Green, K.; Brooks, J.; Mocko, G.; Walker, I.; Healy, S. Patterns in Architecture, Cognition, Systems, and Software: Representing and Analyzing Cognition during the Design Process. In Proceedings of the ANFA Conference-Poster Session; Academy of Neuroscience for Architecture: La Jolla, CA, USA, 2012.

501. Wiesmann, M.; Ishai, A. Expertise reduces neural cost but does not modulate repetition suppression. Cogn. Neurosci. 2011, 2, 57-65. [CrossRef]

502. Hoffman, M. Neural Mechanisms of Place Attachment. In Proceedings of the ANFA Conference-Poster Session; Academy of Neuroscience for Architecture: La Jolla, CA, USA, 2012.

503. Golledge, R.G. Human wayfinding and cognitive maps. In Wayfinding Behavior: Cognitive Mapping and Other Spatial Processes; Golledge, R.G., Ed.; Johns Hopkins University Press: Baltimore, MD, USA, 1999; pp. 5-45.

504. Hillier, B.; Hanson, J. The Social Logic of Space; Cambridge University Press: Cambridge, UK, 1984.

505. Peponis, J.; Wineman, J. Spatial structure of environment and behavior. In Handbook of Environmental Psychology; Bechtel, R.B., Churchman, A., Eds.; Wiley \& Sons: New York, NY, USA, 2002; pp. 271-291.

506. Edelstein, E.A.; Gramann, K.; Schulze, J.; Shamlo, N.B.; van Erp, E.; Vankov, A.; Makeig, S.; Wolszon, L.; Macagno, E. Neural Responses during Navigation in the Virtual Aided Design Laboratory Brain Dynamics of Orientation in Architecturally Ambiguous Space. In Proceedings of the Movement and Orientation in Built Environments: Evaluating Design Rationale and User Cognition; Haq, S., Hölscher, C., Torgrude, S., Eds.; SFB/TR 8: Veracruz, Mexico, 2008; pp. 35-41.

507. Brainard, G.C.; Hanifin, J.P.; Greeson, J.M.; Byrne, B.; Glickman, G.; Gerner, E.; Rollag, M.D. Action spectrum for melatonin regulation in humans: Evidence for a novel circadian photoreceptor. J. Neurosci. 2001, 21, 6405-6412. [CrossRef]

508. Thapan, K.; Arendt, J.; Skene, D.J. An action spectrum for melatonin suppression: Evidence for a novel non-rod, non-cone photoreceptor system in humans. J. Physiol. 2001, 535, 261-267. [CrossRef] [PubMed]

509. Ellis, E.V.; Gonzalez, E.W.; McEachron, D.L. Chronobioengineering indoor lighting to enhance facilities for ageing and Alzheimer's disorder. Intell. Build. Int. 2013, 5, 48-60. [CrossRef]

510. Edelstein, E.A. Influence of architectural lighting on health. Inf. Newsl. 2009, 7, 1-5.

511. Ising, H.; Raun, C. Acute and chronic endocrine effects of noise: Review of the research conducted at the Institute for Water, Soil and Air Hygiene. Noise Heal. 2000, 2, 7. 
512. Alvarsson, J.J.; Wiens, S.; Nilsson, M.E. Stress recovery during exposure to nature sound and environmental noise. Int. J. Environ. Res. Public Health 2010, 7, 1036-1104. [CrossRef]

513. Martínez-Soto, J.; Gonzales-Santos, L.; Pasaye, E.; Barrios, F.A. Exploration of neural correlates of restorative environment exposure through functional magnetic resonance. Intell. Build. Int. 2013, 5, 10-28. [CrossRef]

514. Choi, Y.; Kim, M.; Chun, C. Measurement of occupants' stress based on electroencephalograms (EEG) in twelve combined environments. Build. Environ. 2015, 88, 65-72. [CrossRef]

515. Martínez Soto, J.; Nanni, M.; Gonzales-Santos, L.; Pasaye, E.; Barrios, F. Neural responses to restorative environments: An Eye Tracking and fMRI study. In Proceedings of the 2014 ANFA Conference; Albright, T., Cooke, G., Marks, F., Whitelaw, A., Macagno, E., Eds.; The Academy of Neuroscience for Architecture: La Jolla, CA, USA, 2014; pp. 62-63.

516. Tilley, S.; Neale, C.; Patuano, A.; Cinderby, S. Older people's experiences of mobility and mood in an urban environment: A mixed methods approach using electroencephalography (EEG) and interviews. Int. J. Environ. Res. Public Health 2017, 14, 151. [CrossRef]

517. Alvarez, A. Museum of Memory: An analysis of how museum circulation can help visitors remember a space. In Proceedings of the 2014 ANFA Conference; Albright, T., Cooke, G., Marks, F., Whitelaw, A., Macagno, E., Eds.; The Academy of Neuroscience for Architecture: La Jolla, CA, USA, 2014; pp. 8-9.

518. Du, S.; Shu, E.; Tong, F.; Ge, Y.; Li, L.; Qiu, J.; Guillotel, P.; Fleureau, J.; Danieau, F.; Muller, D. Visualizing the emotional journey of a museum. In Proceedings of the 2016 EmoVis Conference on Emotion and Visualization; Kerren, A., Cernea, D., Pohl, M., Eds.; Linkoping University: Sonoma, CA, USA, 2016; pp. 7-14.

519. Kirchberg, V.; Tröndle, M. The museum experience: Mapping the experience of fine art. Curator Museum J. 2015, 58, 169-193. [CrossRef]

520. Tschacher, W.; Greenwood, S.; Kirchberg, V.; Wintzerith, S.; van den Berg, K.; Tröndle, M. Physiological correlates of aesthetic perception of artworks in a museum. Psychol. Aesthet. Creat. Arts 2012, 6, 96. [CrossRef]

521. Lacuesta, R.; Garcia, L.; García-Magariño, I.; Lloret, J. System to recommend the best place to live based on wellness state of the user employing the heart rate variability. IEEE Access 2017, 5, 10594-10604. [CrossRef]

522. Tsunetsugu, Y.; Miyazaki, Y.; Sato, H. Visual effects of interior design in actual-size living rooms on physiological responses. Build. Environ. 2005, 40, 1341-1346. [CrossRef]

523. Chow, L. Enriched Environment. A Treatment Centre for Transitional Youth with Mental Illness. Ph.D. Thesis, Carleton University, Ottawa, ON, Canada, 2015.

524. Kayan, C. Neuro-Architecture. Enriching Healthcare Environments for Children. Master's Thesis, Chalmers University of Technology, Göteborg, Sweden, 2011.

525. Edelstein, E.A. Translational Design: The intersection of Neuroscience and Architecture. Master's Thesis, New School of Architecture \& Design, San Diego, CA, USA, 2006.

526. Arbib, M.A. The challenge of adapting Neuroscience to the needs of Architecture. In Proceedings of the 2014 ANFA Conference; Albright, T., Cooke, G., Marks, F., Whitelaw, A., Macagno, E., Eds.; The Academy of Neuroscience for Architecture: La Jolla, CA, USA, 2014; pp. 12-13.

527. Dance, A. The brain within buildings. Proc. Natl. Acad. Sci. USA 2017, 114, 785-787. [CrossRef] [PubMed]

528. Gramann, K.; Müller, H.J.; Schönebeck, B.; Debus, G. The neural basis of ego-and allocentric reference frames in spatial navigation: Evidence from spatio-temporal coupled current density reconstruction. Brain Res. 2006, 1118, 116-129. [CrossRef] [PubMed]

529. Zhang, L.; Gossmann, J.; Stevenson, C.; Chi, M.; Cauwenberghs, G.; Gramann, K.; Schulze, J.; Otto, P.; Tzyy-Ping, J.; Peterson, R.; et al. Spatial cognition and architectural design in 4d immersive virtual reality: Testing cognition with a novel audiovisual cave-cad tool. In Proceedings of the Proceedings of the Spatial Cognition for Architectural Design Conference; Bhatt, M., Hölscher, C., Shipley, T.F., Eds.; New York, NY, USA, 2011; pp. 41-50.

530. Marchette, S.A.; Vass, L.K.; Ryan, J.; Epstein, R.A. Outside looking in: Landmark generalization in the human navigational system. J. Neurosci. 2015, 35, 14896-14908. [CrossRef]

531. Burgess, N.; Maguire, E.A.; Spiers, H.J.; O’Keefe, J. A temporoparietal and prefrontal network for retrieving the spatial context of lifelike events. Neuroimage 2001, 14, 439-453. [CrossRef]

532. Aguirre, G.K.; Zarahn, E.; D'esposito, M. An area within human ventral cortex sensitive to "building" stimuli: Evidence and implications. Neuron 1998, 21, 373-383. [CrossRef]

533. Banaei, M.; Hatami, J.; Yazdanfar, A.; Gramann, K. Walking through Architectural Spaces: The Impact of Interior Forms on Human Brain Dynamics. Front. Hum. Neurosci. 2017, 11, 477. [CrossRef] [PubMed]

534. Vartanian, O.; Navarrete, G.; Chatterjee, A.; Fich, L.B.; Gonzalez-Mora, J.L.; Leder, H.; Modroño, C.; Nadal, M.; Rostrup, N.; Skov, M. Architectural design and the brain: Effects of ceiling height and perceived enclosure on beauty judgments and approach-avoidance decisions. J. Environ. Psychol. 2015, 41, 10-18. [CrossRef]

535. McNaughton, B.L.; Battaglia, F.P.; Jensen, O.; Moser, E.I.; Moser, M.B. Path integration and the neural basis of the'cognitive map. Nat. Rev. Neurosci. 2006, 7, 663-678. [CrossRef]

536. O'Keefe, J.; Nadel, L. The Hippocampus as a Cognitive Map; Clarendon Press: Oxford, UK, 1978.

537. Zola-Morgan, S.; Squire, L.R.; Amaral, D.G. Human amnesia and the medial temporal region: Enduring memory impairment following a bilateral lesion limited to field CA1 of the hippocampus. J. Neurosci. 1986, 6, 2950-2967. [CrossRef] 
538. Ekstrom, A.D.; Caplan, J.B.; Ho, E.; Shattuck, K.; Fried, I.; Kahana, M.J. Human hippocampal theta activity during virtual navigation. Hippocampus 2005, 15, 881-889. [CrossRef]

539. Epstein, R.; Harris, A.; Stanley, D.; Kanwisher, N. The parahippocampal place area: Recognition, navigation, or encoding? Neuron 1999, 23, 115-125. [CrossRef]

540. Burgess, N.; Maguire, E.; O'Keefe, J. The human hippocampus and spatial and episodic memory. Neuron 2002, 35, 625-641. [CrossRef]

541. Nasr, S.; Echavarria, C.E.; Tootell, R.B. Thinking outside the box: Rectilinear shapes selectively activate scene-selective cortex. J. Neurosci. 2014, 34, 6721-6735. [CrossRef] [PubMed]

542. Kacha, L.; Matsumoto, N.; Mansouri, A. Electrophysiological Evaluation of Perceived Complexity in Streetscapes. J. Asian Archit. Build. Eng. 2015, 14, 585-592. [CrossRef]

543. Banaei, M.; Yazdanfar, A.; Nooreddin, M.; Yoonessi, A. Enhancing urban trails design quality by using electroencephalography device. Procedia-Soc. Behav. Sci. 2015, 201, 386-396. [CrossRef]

544. Kober, S.E.; Neuper, C. Sex differences in human EEG theta oscillations during spatial navigation in virtual reality. Int. J. Psychophysiol. 2011, 79, 347-355. [CrossRef] [PubMed]

545. Ancoli-Israel, S.; Martin, J.L.; Gehrman, P.; Shochat, T.; Corey-Bloom, J.; Marler, M.; Nolan, S.; Levi, L. Effect of light on agitation in institutionalized patients with severe Alzheimer disease. Am. J. Geriatr. Psychiatry 2003, 11, 194-203. [CrossRef]

546. Kobayashi, H.; Sato, M. Physiological Responses to llluminance and Color Temperature of Lighting. Ann. Physiol. Anthropol. 1992, 11, 45-49. [CrossRef]

547. Noguchi, H.; Sakaguchi, T. Effect of illuminance and color temperature on lowering of physiological activity. Appl. Hum. Sci. 1999, 18, 117-123. [CrossRef]

548. Minguillon, J.; Lopez-Gordo, M.A.; Renedo-Criado, D.A.; Sanchez-Carrion, M.J.; Pelayo, F. Blue lighting accelerates post-stress relaxation: Results of a preliminary study. PLoS ONE 2017, e0186399. [CrossRef]

549. Shin, Y.B.; Woo, S.H.; Kim, D.H.; Kim, J.; Kim, J.J.; Park, J.Y. The effect on emotions and brain activity by the direct/indirect lighting in the residential environment. Neurosci. Lett. 2015, 584, 28-32. [CrossRef]

550. Soto Magan, V.E.; Webler, F.S.; Andersen, M. Perceived and yet not seen: Non-visual effects in daylit spaces. In Proceedings of the 2018 ANFA Conference; The Academy of Neuroscience for Architecture: La Jolla, CA, USA, 2018; pp. 94-95.

551. Küller, R.; Mikellides, B.; Janssens, J. Color, arousal, and performance-A comparison of three experiments. Color Res. Appl. 2009, 34, 141-152. [CrossRef]

552. Vartanian, O.; Navarrete, G.; Chatterjee, A.; Fich, L.B.; Leder, H.; Modroño, C.; Nadal, M.; Rostrup, N.; Skov, M. Impact of contour on aesthetic judgments and approach-avoidance decisions in architecture. Proc. Natl. Acad. Sci. USA 2013, 110, 10446-10453. [CrossRef] [PubMed]

553. Oppenheim, I.; Mühlmann, H.; Blechinger, G.; Mothersill, I.W.; Hilfiker, P.; Jokeit, H.; Kurthen, M.; Krämer, G.; Grunwald, T. Brain electrical responses to high- and low-ranking buildings. Clin. EEG Neurosci. 2009, 40, 157-161. [CrossRef] [PubMed]

554. Mecklinger, A.; Kriukova, O.; Mühlmann, H.; Grunwald, T. Cross-cultural differences in processing of architectural ranking: Evidence from an event-related potential study. Cogn. Neurosci. 2014, 5, 45-53. [CrossRef] [PubMed]

555. Shemesh, A.; Talmon, R.; Karp, O.; Amir, I.; Bar, M.; Grobman, Y.J. Affective response to architecture-investigating human reaction to spaces with different geometry. Archit. Sci. Rev. 2016, 60, 116-125. [CrossRef]

556. Bertamini, M.; Palumbo, L.; Gheorghes, T.N.; Galatsidas, M. Do observers like curvature or do they dislike angularity? Br. J. Psychol. 2016, 107, 154-178. [CrossRef] [PubMed]

557. Pati, D.; O’Boyle, M.; Hou, J.; Nanda, U.; Ghamari, H. Can hospital form trigger fear response? HERD Heal. Environ. Res. Des. J. 2016, 9, 162-175. [CrossRef] [PubMed]

558. Lindberg, C.M. Wellbuilt for wellbeing: Using sensors and surveys to explore the indoor environment and health. In Proceedings of the 2018 ANFA Conference; The Academy of Neuroscience for Architecture: La Jolla, CA, USA, 2018; pp. 90-91.

559. Kallai, J.; Makany, T.; Csatho, A.; Karadi, K.; Horvath, D.; Kovacs-Labadi, B.; Jarai, R.; Nadel, L.; Jacobs, J.W. Cognitive and affective aspects of thigmotaxis strategy in humans. Behav. Neurosci. 2007, 121, 21-30. [CrossRef] [PubMed]

560. Sussman, A.; Hollander, J.B. Cognitive Architecture: Designing for How We Respond to the Built Environment; Routledge: New York, NY, USA, 2014.

561. Fich, L.B.; Gimmier, A.; Petrini, L.; Jelic, A.; Djebbara, Z.; Jönsson, P. Does views to nature and the design of spaces matter? In Proceedings of the 2018 ANFA Conference; The Academy of Neuroscience for Architecture: La Jolla, CA, USA, 2018; pp. 68-69.

562. Chamilothori, K.; Chinazzo, G.; Rodrigues, J.; Dan-Glauser, E.; Wienold, J.; Andersen, M. Perceived interest and heart rate response to façade and daylight patterns in virtual reality. In Proceedings of the 2018 ANFA Conference; The Academy of Neuroscience for Architecture: La Jolla, CA, USA, 2018; pp. 42-43.

563. Vecchiato, G.; Jelic, A.; Tieri, G.; Maglione, A.G.; De Matteis, F.; Babiloni, F. Neurophysiological correlates of embodiment and motivational factors during the perception of virtual architectural environments. Cogn. Process. 2015, 16, 425-429. [CrossRef] [PubMed]

564. Choo, H.; Nasar, J.L.; Nikrahei, B.; Walther, D.B. Neural codes of seeing architectural styles. Sci. Rep. 2017, 7, 40201. [CrossRef] [PubMed]

565. Vecchiato, G.; Tieri, G.; Jelic, A.; De Matteis, F.; Maglione, A.G.; Babiloni, F. Electroencephalographic correlates of sensorimotor integration and embodiment during the appreciation of virtual architectural environments. Front. Psychol. 2015, 6, 1944. [CrossRef] [PubMed] 
566. Ulrich, R.S. Human responses to vegetation and landscapes. Landsc. Urban Plan. 1986, 13, 29-44. [CrossRef]

567. Laumann, K.; Gärling, T.; Stormark, K.M. Selective attention and heart rate responses to natural and urban environments. J. Environ. Psychol. 2003, 23, 125-134. [CrossRef]

568. Mazumder, R.; Ellard, C. The space between: An exploration into how urban environments influence affect and distance perception. In Proceedings of the 2018 ANFA Conference; The Academy of Neuroscience for Architecture: La Jolla, CA, USA, 2018; pp. 104-105.

569. Navarrete, D.A. Applied cognitive architecture: The restorative impact of perceived open space. In Proceedings of the 2018 ANFA Conference; The Academy of Neuroscience for Architecture: La Jolla, CA, USA, 2018; pp. 122-123.

570. Skov, M. Neuroaesthetic problems: A framework for neuroaesthetic research. In Neuroaesthetics; Skov, M., Vartanian, O., Eds.; Baywood Publishing: Amityville, NY, USA, 2009; pp. 9-26.

571. Bruce, V.; Green, P.R.; Georgeson, M.A. Visual Perception: Physiology, Psychology and Ecology; Psychology Press: New York, NY, USA, 2003.

572. Bourdieu, P. Social space and symbolic power. Sociol. Theory 1989, 7, 14-25. [CrossRef]

573. Ebrahem, S. Exploring the phenomenological perception of the architectural spatial experience. In Proceedings of the 2018 ANFA Conference; The Academy of Neuroscience for Architecture: La Jolla, CA, USA, 2018; pp. 56-57.

574. O'Neill, M.E. Corporeal experience: A haptic way of knowing. J. Archit. Educ. 2001, 55, 3-12. [CrossRef]

575. Jacobsen, T.; Buchta, K.; Kohler, M.; Schroger, E. The primacy of beauty in judging the aesthetics of objects. Psychol. Rep. 2004, 94, 1253-1260. [CrossRef] [PubMed]

576. Richter, H.; Britt, D. Dada, Art and Anti-Art, World of Art; Thames \& Hudson: New York, NY, USA, 1997.

577. Clay, F. The origin of the aesthetic emotion. Sammelbände Int. Musik. 1908, 9, 282-290.

578. Brown, S.; Dissanayake, E. The arts are more than aesthetics: Neuroaesthetics as narrow aesthetics. In Neuroaesthetics; Skov, M., Vartanian, O., Eds.; Baywood Publishing: Amityville, NY, USA, 2009; pp. 43-57.

579. Poldrack, R.A. Can cognitive processes be inferred from neuroimaging data? Trends Cogn. Sci. 2006, 10, 59-63. [CrossRef]

580. Cacioppo, J.T.; Berntson, G.G.; Larsen, J.T.; Poehlmann, K.M.; Ito, T.A. The Psychophysiology of Emotion. In Handbook of Emotions; Lewis, M., Haviland-Jones, J.M., Barrett, L.F., Eds.; Guilford Press: New York, NY, USA, 2000; pp. $173-191$.

581. Winkielman, P.; Cacioppo, J.T. Mind at ease puts a smile on the face: Psychophysiological evidence that processing facilitation elicits positive affect. J. Pers. Soc. Psychol. 2001, 81, 989-1000. [CrossRef] [PubMed]

582. Lindquist, M.; Williams, A.; Oloyede, A. Wearable neuroimaging and emotion: Investigating emotional responses to architectural environments with functional near-Infrared spectroscopy (fNIRS). In Proceedings of the 2014 ANFA Conference; Albright, T., Cooke, G., Marks, F., Whitelaw, A., Macagno, E., Eds.; The Academy of Neuroscience for Architecture: La Jolla, CA, USA, 2014; p. 58.

583. Babiloni, F.; Cherubino, P.; Graziani, I.; Trettel, A.; Bagordo, G.M.; Cundari, C.; Borghini, G.; Aricò, P.; Maglione, A.G.; Vecchiato, G. The great beauty: A by neuroelectric imaging during the observation of the real Michelangelo's Moses sculpture. In Proceedings of the 36th Annual International Conference of the IEEE Engineering in Medicine and Biology Society, Chicago, IL, USA, 26-30 August 2014; IEEE: Piscataway, NJ, USA, 2014; pp. 6965-6968.

584. Siddharth Patel, A.N.; Jung, T.P.; Sejnowski, T.J. A wearable multi-modal bio-sensing system towards real-world applications. IEEE Trans. Biomed. Eng. 2018, 66, 1137-1147. [CrossRef]

585. Smith, M.; Nanda, U.; Macagno, E.; Greving, T. A culture of experimentation: From the torrey pines living lab to emerging neuroarchitecture lab. In Proceedings of the 2018 ANFA Conference; The Academy of Neuroscience for Architecture: La Jolla, CA, USA, 2018; pp. 174-175.

586. Locher, P.; Krupinski, E.A.; Mello-Thoms, C.; Nodine, C.F. Visual interest in pictorial art during an aesthetic experience. Spat. Vis. 2007, 21, 55-77. [CrossRef] [PubMed]

587. Andreasen, M.E.K. Make a safe environment by design. J. Gerontol. Nurs. 1985, 11, 18-22. [CrossRef] [PubMed]

588. Batteux, C. Les Beaux Arts Réduits à un Même Principe; Durand: Paris, France, 1746.

589. Holl, S. Cuestiones de Percepción: Fenomenología de la Arquitectura; Gustavo Gili: Barcelona, Spain, 2011; ISBN 9788425224058.

590. Djebbara, Z. Incentive architecture: Neural correlates of spatial affordances during transition in architectural settings. In Proceedings of the 2018 ANFA Conference; The Academy of Neuroscience for Architecture: La Jolla, CA, USA, 2018; pp. 52-53.

591. Srikantharajah, J.; Ellard, C.; Condia, B. Place, peripheral vision, and space perception: A pilot study in VR. In Proceedings of the 2018 ANFA Conference; The Academy of Neuroscience for Architecture: La Jolla, CA, USA, 2018; pp. 180-181.

592. Rooney, K.K.; Condia, R.J.; Loschky, L.C. Focal and ambient processing of built environments: Intellectual and atmospheric experiences of architecture. Front. Psychol. 2017, 8, 326. [CrossRef] [PubMed]

593. Mehta, B.K. Smell and the architectural experience. In Proceedings of the 2014 ANFA Conference; Albright, T., Cooke, G., Marks, F., Whitelaw, A., Macagno, E., Eds.; The Academy of Neuroscience for Architecture: La Jolla, CA, USA, $2014 ;$ p. 68.

594. Marks, L.E. The Unity of the Senses: Interrelations among the Modalities; Academic Press: London, UK, 1978.

595. Jones, P.B.; Canniffe, E. Modern Architecture through Case Studies 1945-1990; Architectural Press: Oxford, UK, 2007.

596. Trehub, S.E. Human processing predispositions and musical universals. In The Origins of Music; Wallin, N.L., Merker, B., Brown, S., Eds.; MIT Press: Cambridge, MA, USA, 2000; pp. 427-448.

597. Dutton, D. The Art Instinct: Beauty, Pleasure, E Human Evolution; Oxford University Press: New York, NY, USA, 2009. 
598. Child, I.L. Aesthetic theories. In Handbook of Perception; Carterette, E.C., Friedman, M.P., Eds.; Academic Press: New York, NY, USA, 1978; pp. 111-131.

599. Reber, R.; Schwarz, N.; Winkielman, P. Processing Fluency and Aesthetic Pleasure: Is Beauty in the Perceiver's Processing Experience? Personal. Soc. Psychol. Rev. 2004, 8, 364-382. [CrossRef] [PubMed]

600. Zumthor, P. Pensar la Arquitectura; Gustavo Gili: Barcelona, Spain, 2014.

601. Appenzeller, T. Evolution or Revolution? Science 1998, 282, 1451-1454. [CrossRef]

602. Skov, M.; Nadal, M. Art is not special: An assault on the last lines of defense against the naturalization of the human mind. Rev. Neurosci. 2018, 29. [CrossRef]

603. Rakic, P. Neurogenesis in adult primate neocortex: An evaluation of the evidence. Nat. Rev. Neurosci. 2002, 3, 65-71. [CrossRef]

604. Livingston, R.B. Brain mechanisms in conditioning and learning. Neurosci. Res. Program Bull. 1966, 4, 349-354.

605. Kozbelt, A. Tensions in naturalistic, evolutionary explanations of aesthetic reception and production. New Ideas Psychol. 2017, 47, 113-120. [CrossRef]

606. Whitfield, A. Individual differences in evaluation of architectural colour: Categorization effects. Percept. Mot. Skills 1984, 59, 183-186. [CrossRef]

607. Vessel, E.A.; Maurer, N.; Denker, A.H.; Starr, G.G. Stronger shared taste for natural aesthetic domains than for artifacts of human culture. Cognition 2018, 179, 121-131. [CrossRef]

608. Swaab, D. Somos Nuestro Cerebro; Plataforma: Barcelona, Spain, 2014.

609. Cupchik, G.C.; Winston, A.S.; Herz, R.S. Judgments of similarity and difference between paintings. Vis. Arts Res. 1992, 14, 37-50.

610. Ackerman, D. Una Historia Natural de los Sentidos; Anagrama: Barcelona, Spain, 1992.

611. Pallasmaa, J.; Mallgrave, H.F.; Arbib, M.A. Architecture and Neuroscience; Tapio Wirkkala-Rut Bryk Foundation: Helsinki, Finland, 2013.

612. Eberhard, J.P. Sustainability and Neuroscience. In Sustainable Environmental Design in Architecture: Impacts on Health; Rassia, S.T., Pardalos, P.M., Eds.; Springer: New York, NY, USA, 2012; pp. 3-6.

613. Sternberg, E.M. Healing Spaces; Harvard University Press: London, UK, 2009.

614. Turk, M.R.; Amr, A.; Al Rawi, O. A school designed to improve student's brain activity using integrated neuro-architectural design aspects (qeeg-vr). In Proceedings of the 2018 ANFA Conference; The Academy of Neuroscience for Architecture: La Jolla, CA, USA, 2018; pp. 146-147.

615. Goldstein, R.N. Architectural design and the collaborative research environment. Cell 2006, 127, 243-246. [CrossRef] [PubMed]

616. Auvray, M.; Spence, C. The multisensory perception of flavor. Conscious. Cogn. 2008, 17, 1016-1031. [CrossRef]

617. Hollander, J.; Foster, V. Brain responses to architecture and planning: A preliminary neuro-assessment of the pedestrian experience in Boston, Massachusetts. Archit. Sci. Rev. 2016, 59, 474-481.

618. Mavros, P.; Austwick, M.Z.; Smith, A.H. Geo-EEG: Towards the use of EEG in the study of urban behaviour. Appl. Spat. Anal. Policy 2016, 9, 191-212. [CrossRef]

619. Portugali, J. Toward a cognitive approach to urban dynamics. Environ. Plan. B Plan. Des. 2004, 31, 589-613. [CrossRef]

620. Taylor-Hochberg, A. Emerging methodologies of neuro-urbanism: Operationalizing neuroscience in architecture and urban planning practice. In Proceedings of the 2018 ANFA Conference; The Academy of Neuroscience for Architecture: La Jolla, CA, USA, 2018; pp. 186-187.

621. Barrett, P.; Sharma, M.; Zeisel, J. Optimal spaces for those living with dementia: Principles and evidence. Build. Res. Inf. 2019, 47, 734-746. [CrossRef]

622. Zeisel, J. Improving person-centered care through effective design. Generations 2013, 37, 45-52.

623. Zuanon, R.; de Faria, B.A. Landscape Design and Neuroscience Cooperation: Contributions to the Non-pharmacological Treatment of Alzheimer's Disease. In Digital Human Modeling. Applications in Health, Safety, Ergonomics, and Risk Management, Proceedings of the Digital Human Modeling. Applications in Health, Safety, Ergonomics, and Risk Management; Duffy, V.G., Ed.; Springer International Publishing: Cham, Switzerland, 2018; pp. 353-374.

624. Slater, M.; Usoh, M.; Steed, A. Depth of Presence in virtual environments. Presence Teleoperators Virtual Environ. 1994, 3, 130-144. [CrossRef]

625. Riches, S.; Elghany, S.; Garety, P.; Rus-Calafell, M.; Valmaggia, L. Factors Affecting Sense of Presence in a Virtual Reality Social Environment: A Qualitative Study. Cyberpsychol. Behav. Soc. Netw. 2019, 22, 288-292. [CrossRef] [PubMed]

626. Diemer, J.; Alpers, G.W.; Peperkorn, H.M.; Shiban, Y.; Mühlberger, A. The impact of perception and presence on emotional reactions: A review of research in virtual reality. Front. Psychol. 2015, 6, 26. [CrossRef] [PubMed]

627. Cipresso, P.; Giglioli, I.A.C.; Raya, M.A.; Riva, G. The Past, Present, and Future of Virtual and Augmented Reality Research: A network and cluster analysis of the literature. Front. Psychol. 2018, 9, 2086. [CrossRef] [PubMed]

628. Kriegeskorte, N.; Simmons, W.K.; Bellgowan, P.S.; Baker, C.I. Circular analysis in systems neuroscience: The dangers of double dipping. Nat. Neurosci. 2009, 12, 535-540. [CrossRef] [PubMed]

629. Picard, R.W. Affective Computing; MIT Press: Cambridge, MA, USA, 2000.

630. Zangeneh Soroush, M.; Maghooli, K.; Setarehdan, S.K.; Motie Nasrabadi, A. A Review on EEG Signals Based Emotion Recognition. Int. Clin. Neurosci. J. 2018, 4, 118-129. [CrossRef]

631. Valenza, G.; Lanata, A.; Scilingo, E.P. The role of nonlinear dynamics in affective valence and arousal recognition. IEEE Trans. Affect. Comput. 2012, 3, 237-249. [CrossRef] 
632. Calvo, R.A.; D'Mello, S. Affect detection: An interdisciplinary review of models, methods, and their applications. IEEE Trans. Affect. Comput. 2018, 4, 118-129. [CrossRef]

633. Camerer, C.; Loewenstein, G.; Prelec, D. Neuroeconomics: How neuroscience can inform economics. J. Econ. Lit. 2005, 43, 9-64. [CrossRef]

634. Fernández-Caballero, A.; Martínez-Rodrigo, A.; Pastor, J.M.; Castillo, J.C.; Lozano-Monasor, E.; López, M.T.; Zangróniz, R.; Latorre, J.M.; Fernández-Sotos, A. Smart environment architecture for emotion detection and regulation. J. Biomed. Inform. 2016, 64, 55-73. [CrossRef]

635. Marín-Morales, J.; Higuera-Trujillo, J.L.; Greco, A.; Guixeres, J.; Llinares, C.; Gentili, C.; Pasquale, E.; Alcañiz, M.; Valenza, G. Real vs. immersive-virtual emotional experience: Analysis of psycho-physiological patterns in a free exploration of an art museum. PLoS ONE 2019, 14, e0223881. [CrossRef] [PubMed]

636. Marín-Morales, J.; Higuera-Trujillo, J.L.; Greco, A.; Guixeres, J.; Llinares, C.; Scilingo, E.P.; Alcañiz, M.; Valenza, G. Affective computing in virtual reality: Emotion recognition from brain and heartbeat dynamics using wearable sensors. Sci. Rep. 2018, 8, 13657. [CrossRef] [PubMed]

637. Marín-Morales, J.; Llinares, C.; Guixeres, J.; Alcañiz, M. Emotion Recognition in Immersive Virtual Reality: From Statistics to Affective Computing. Sensors 2020, 20, 5163. [CrossRef] [PubMed]

638. Arbib, M.A. Brains, machines and buildings: Towards a neuromorphic architecture. Intell. Build. Int. 2012, 4, 147-168. [CrossRef]

639. Arbib, M.A.; Ngoon, T.; Janes, E. From neural space to physical space: Giving a "brain" to a building. In Proceedings of the 2018 ANFA Conference; The Academy of Neuroscience for Architecture: La Jolla, CA, USA, 2018; pp. 16-17.

640. Lehrerm, J. Proust y la Neurociencia; Ediciones Paidós: Barcelona, Spain, 2010.

641. Pepperell, R. Art, Energy and the Brain. In Progress in Brain Research; Christensen, J.F., Gomila, A., Eds.; Elsevier: Amsterdam, The Netherlands, 2018; pp. 417-435.

642. McAuley, L.; Tugwell, P.; Moher, D. Does the inclusion of grey literature influence estimates of intervention effectiveness reported in meta-analyses? Lancet 2000, 356, 1228-1231. [CrossRef]

643. Keehner, M.; Fischer, M.H. Naive realism in public perceptions of neuroimages. Nat. Rev. Neurosci. 2011, 12, 118. [CrossRef]

644. Fitzgerald, D.; Callard, F. Social science and neuroscience beyond interdisciplinarity: Experimental entanglements. Theory, Cult. Soc. 2015, 32, 3-32. [CrossRef] [PubMed] 